\title{
Quality Assurance and Data Management
}

Prepared for the U.S. Department of Energy

5. Fluor Daniel Hanford, Inc.

Richland, Washington

Hanford Management and Integration Contractor for the

U.S. Depertment of Energy under Contract DE-AC-0696-RL 13200 
THIS PAGE INTENTIONALLY

LEFT BLANK 


\title{
Quality Assurance and Data Management
}

\author{
L. L. Lockrem \\ Numatec Hanford Corporation
}

Date Published

January 1998

To Be Presented at

Bangalore University Workshop

India

January $23-25,1998$

Prepared for the U.S. Department of Energy

Fluor Daniel Hanford, Inc.

(马.O. Box 1000

Richland, Washington

Hanford Management and Integration Contractor for the

U.S. Department of Energy under Contract DE-AC-0696-RL13200

Approved for Public Release; Further Dissemination Unlimited 
THIS PAGE INTENTIONALLY LEFT BLANK 
Urban Air Pollution: The Sources, Health/lssues, Monitoring/ Data Management, Control and Regulations

Data Management Relative to Air Measurements

\author{
By \\ L.L. Lockrem
}




\title{
Section I
}

\author{
Intoduction
}

- Opening Remarks

-Introduction to Hanford 


\section{LL (Larry) Lockrem}

- M.S. Geochemistry

- B.S. Chemistry

- 22 Years Experience (Industry Government, Education)

- Areas of Technical Interest

- Vapor-Analysis

- Sampling and Analysis of Atmospheres American Society of Testing Materials

- Asbestos Analysis

- Environmental Laboratory and Field Services

- Spectroscopy and Mineralogy Analysis 


\begin{tabular}{|c|c|c|c|}
\hline & \multicolumn{2}{|c|}{ Special Analytical Support } & \\
\hline $\begin{array}{c}\text { Field } \\
\text { Assessment } \\
\text { Services Team } \\
\end{array}$ & $\begin{array}{c}\text { Organic Sampling } \\
\text { and } \\
\text { Analysis Team }\end{array}$ & $\begin{array}{c}\text { In-Situ } \\
\text { Measurement } \\
\text { Treatment }\end{array}$ & $\begin{array}{l}\text { Baseline } \\
\text { Support }\end{array}$ \\
\hline $\begin{array}{l}\text {-Environmental } \\
\text { Sampling/Analysis } \\
\text {-Waste Sampling/ } \\
\text { Analysis } \\
\text {-Sampling and Field } \\
\text { Management } \\
\text {-Field Team Leaders } \\
\text {-Field Screening } \\
\text {-Operations Sampling/ } \\
\text { Analysis } \\
\text { - Laboratory } \\
\text { Information } \\
\text { Management Systems } \\
\text { Support } \\
\text {-Consulting Services }\end{array}$ & $\begin{array}{l}\text {-Vapor Sampling/ } \\
\text { Analysis } \\
\text {-Develop/Review of } \\
\text { Data Quality Objectives } \\
\text {-Head Space Monitoring } \\
\text {-Screening/Field } \\
\text { Monitoring } \\
\text { - Mobile analytical } \\
\text { Services } \\
\text {-Consulting Services }\end{array}$ & $\begin{array}{l}\text {-In-Situ Characterization } \\
\text { - Field Methods } \\
\text { Development } \\
\text { - Hardware Development } \\
\text { - Non-Destructive Assay } \\
\text { - Fabrication/ } \\
\text { Development } \\
\text { - Radiological Screening } \\
\text { - Consulting Services }\end{array}$ & $\begin{array}{l}\text { Planning/scheduling } \\
\text { - Aecord Management } \\
\text {-Fadilities/Property } \\
\text { Mandgement } \\
\text {-Procunement/Financial } \\
\text { Affairs } \\
\text { - Training } \\
\text { - Contracts Administration } \\
\text { - Marketing/L/Lboratory } \\
\text { Interface } \\
\text {-Quality Assurance } \\
\text { - Hazardous Wałte } \\
\text { Disposal }\end{array}$ \\
\hline $\begin{array}{l}\text { NHC } \\
\text { Numatec Hanford Co } \\
\text { An SGN/Cogema, Inc. Co }\end{array}$ & ation & & HG9712q186. 5 \\
\hline
\end{tabular}




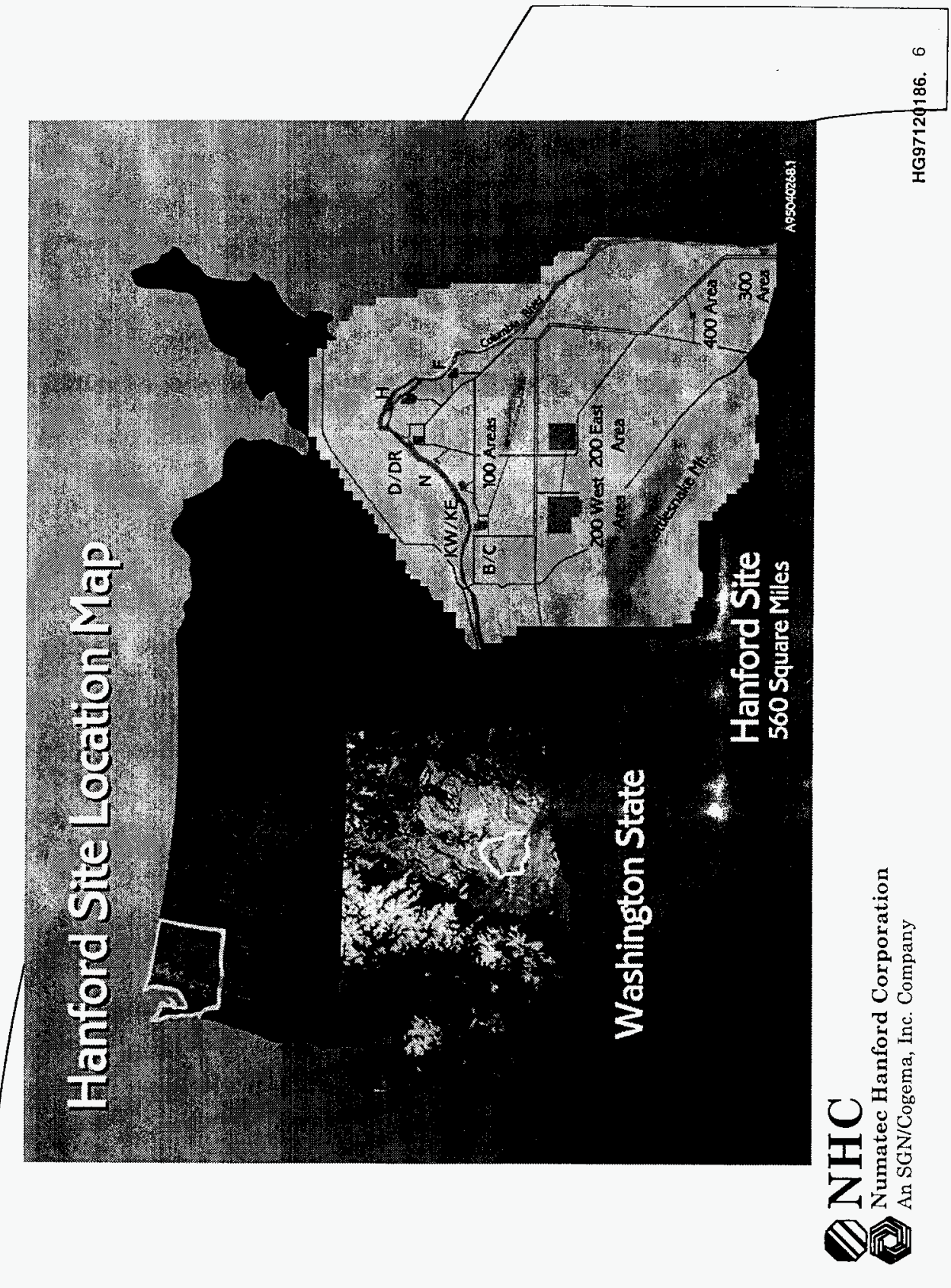




\section{Hanford Site Boundary}

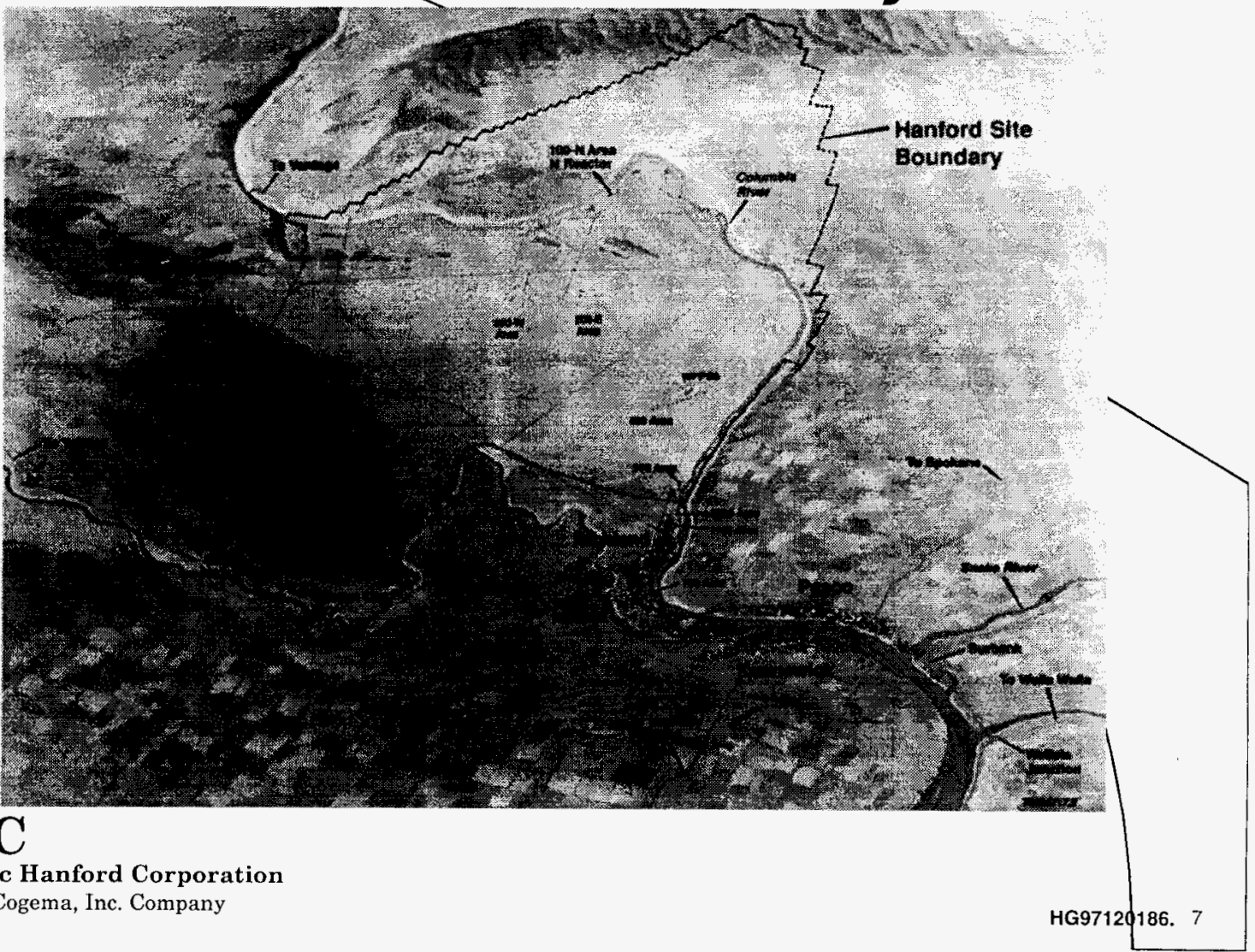




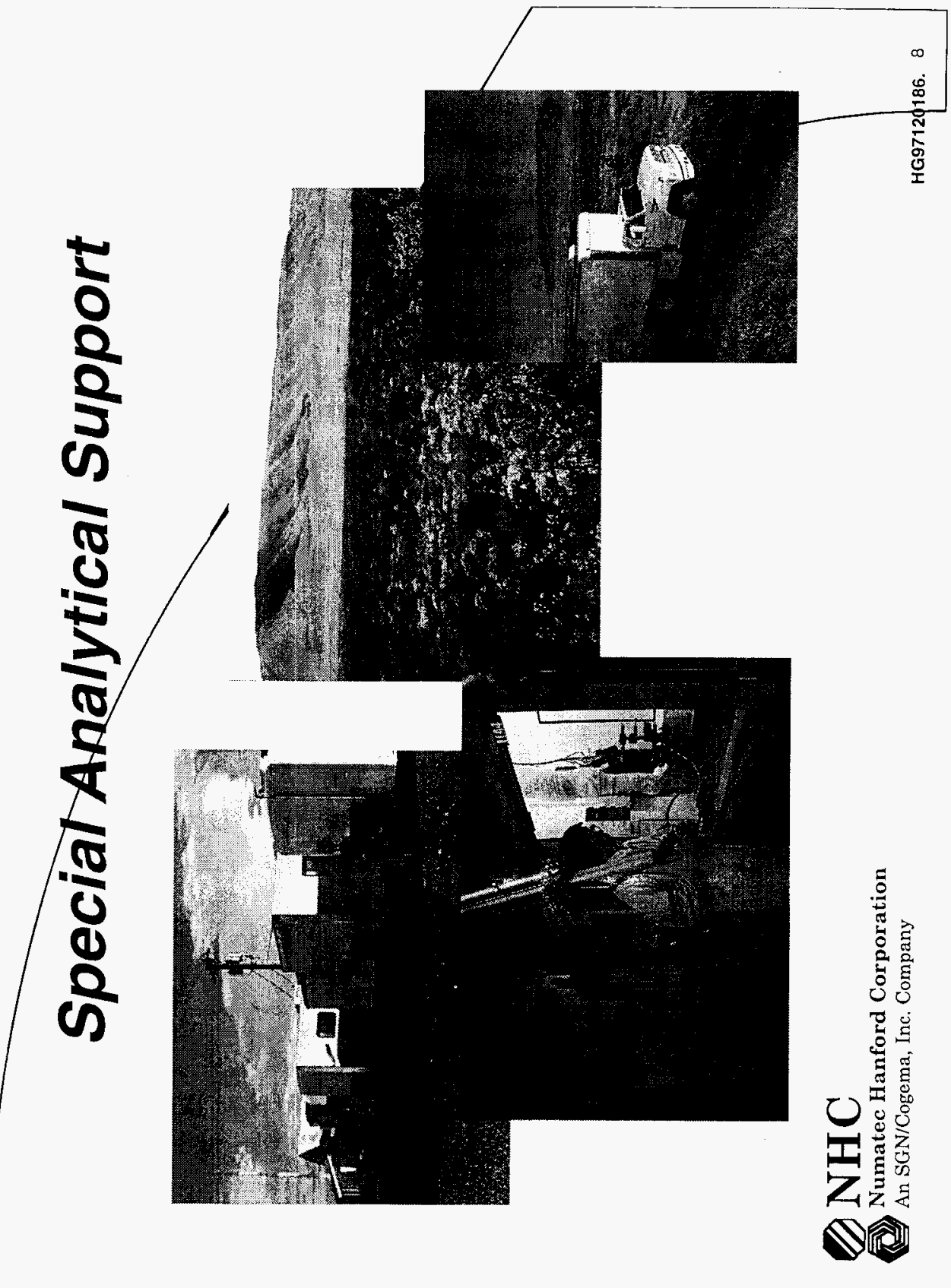




\section{Hanford Laboratory Facility}

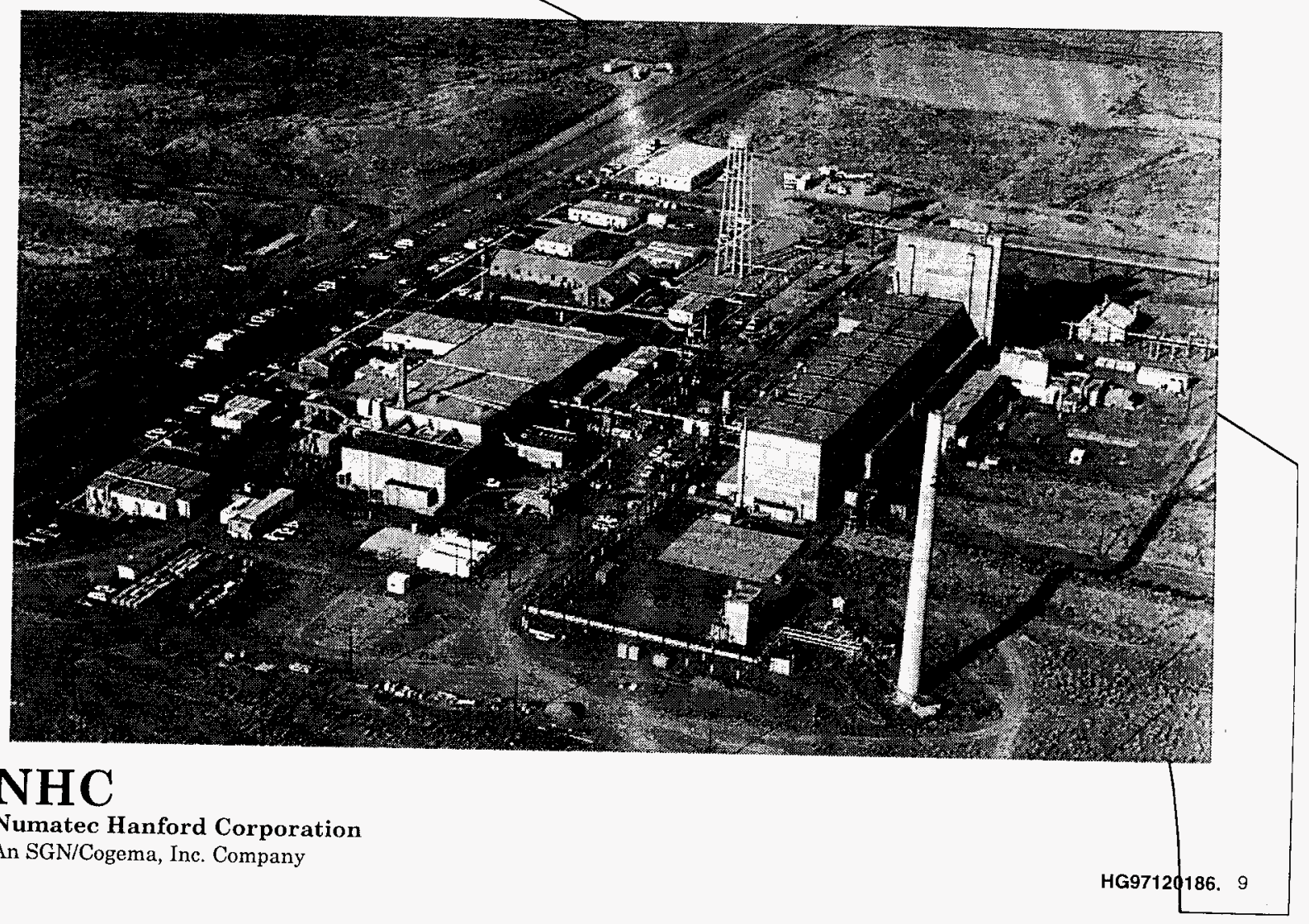




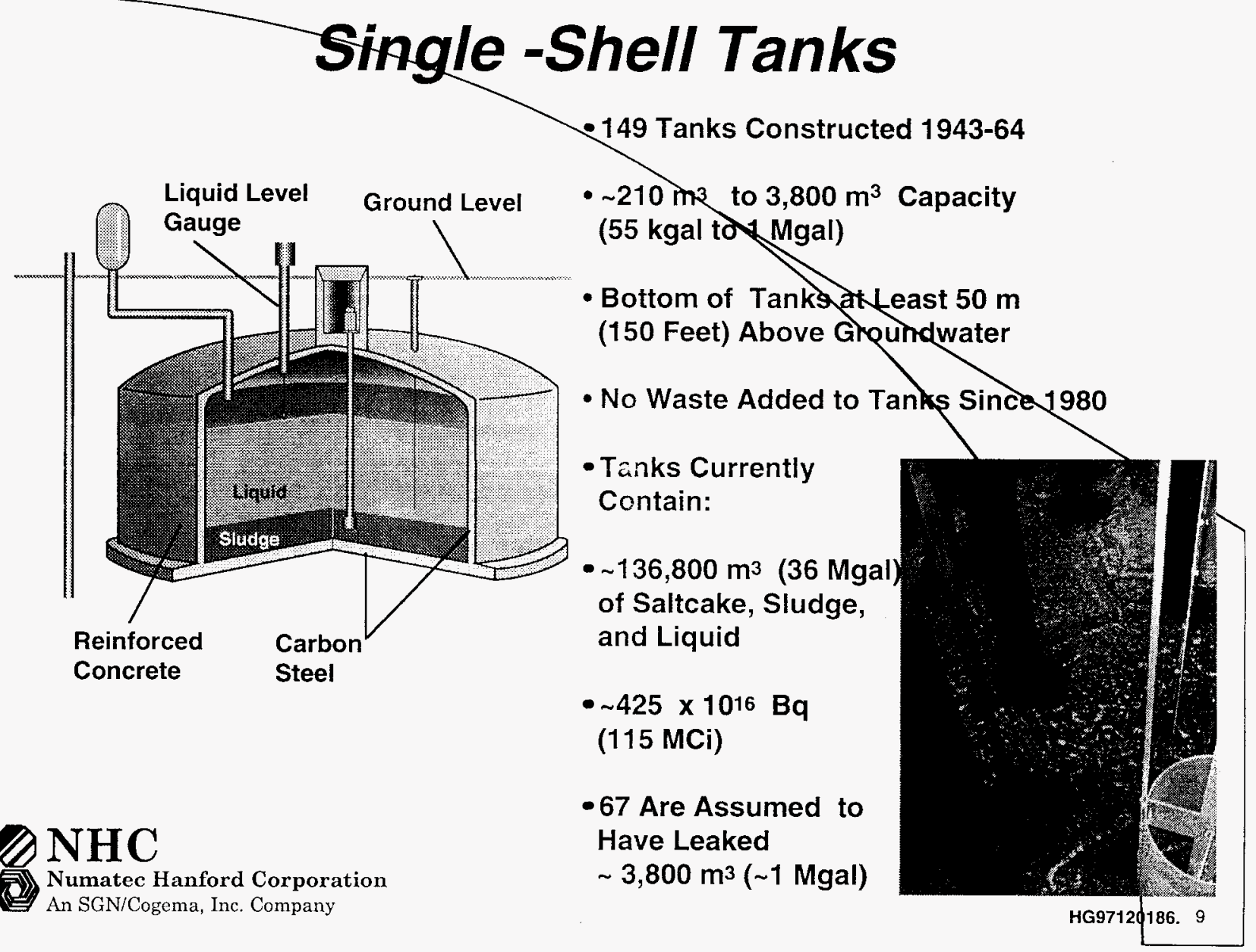




\section{Double-Shell Tanks}

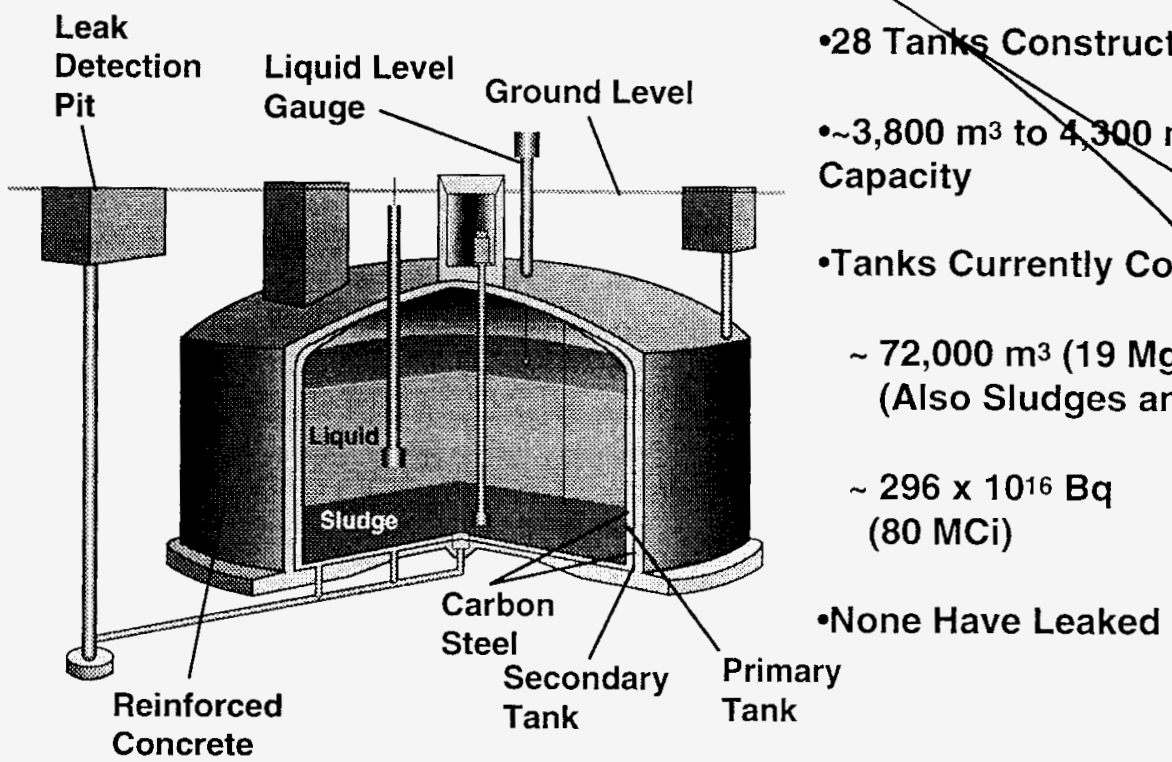

Concrete

NHC

1) Numatec Hanford Corporation

An SGN/Cogema, Inc. Company
Tante

-28 Tanks Constructed Between 1968-86

- 3,800 $\mathrm{m}^{3}$ to $4300 \mathrm{~m}^{3}$ (1 to $1.14 \mathrm{Mgal}$ ) Capacity

Tanks Currently Contain

72,000 $\mathrm{m}^{3}$ (19 Mgal) of Mostly Liquids Also Sludges and Salts)

$296 \times 1016 \mathrm{~Bq}$ (80 MCi)

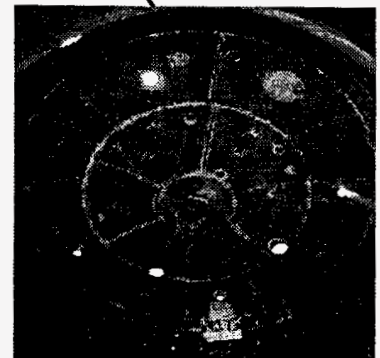

HG97120186. 10 


\section{Current Hanford Tank Waste Volume}

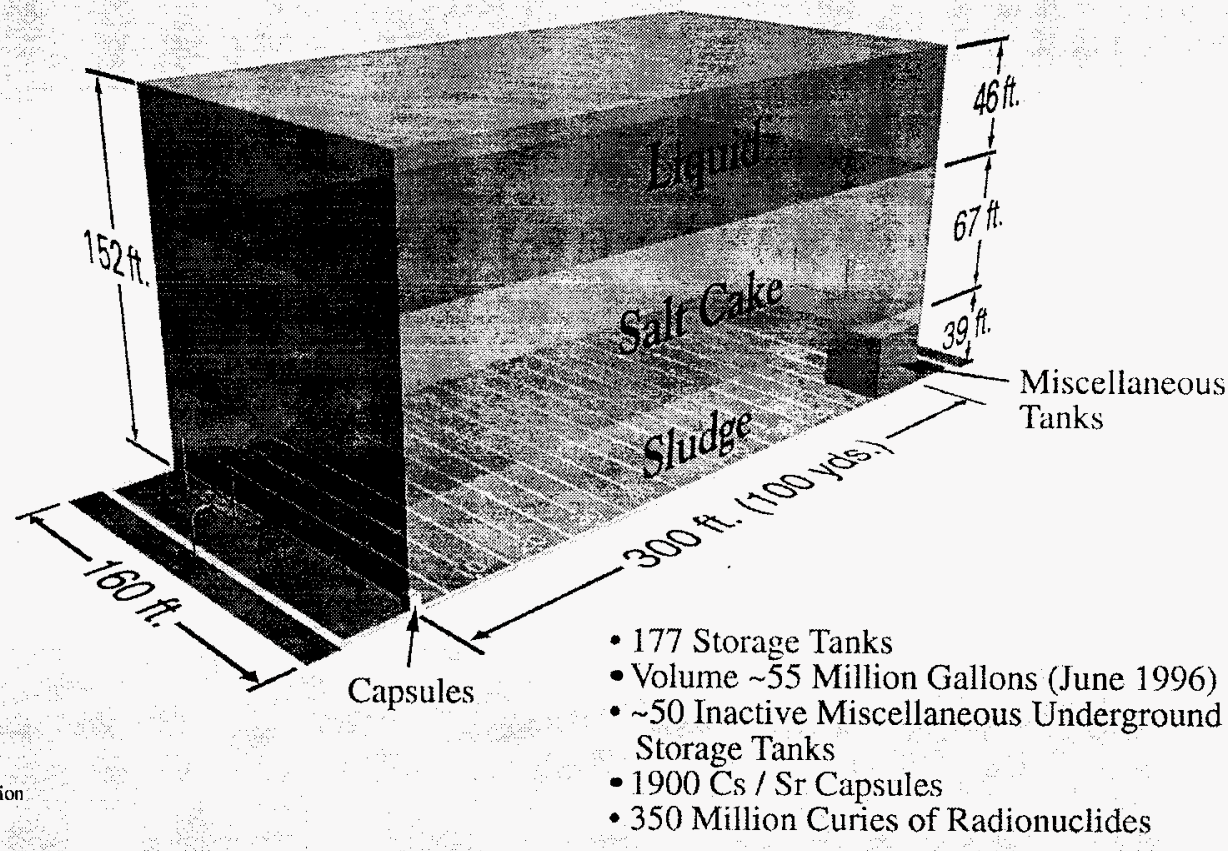

LMSI Animetion

A96060069

- 350 Million Curies of Radionuclides 


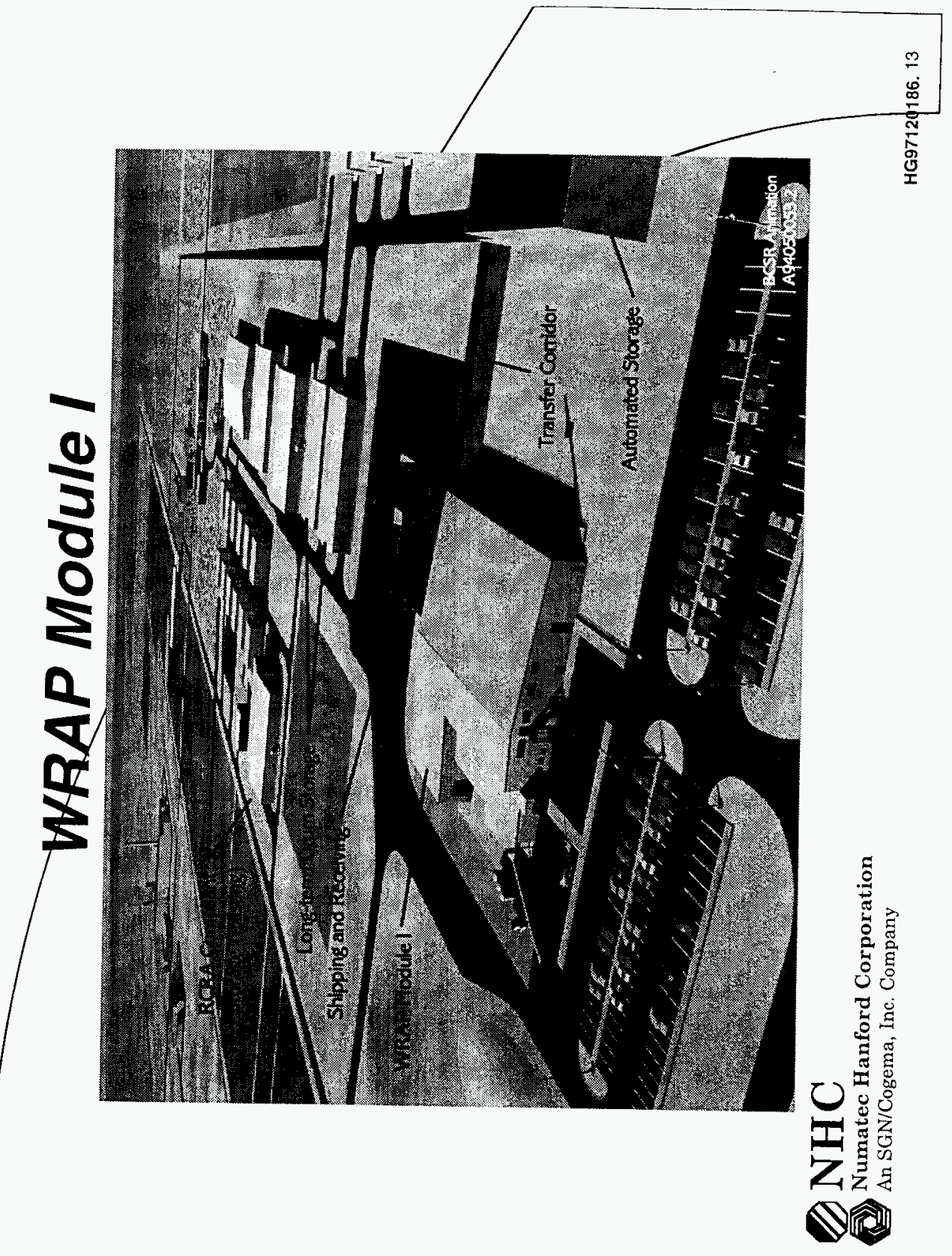




\section{Special Analytical Support Present}

Activities

- Hanford Tank Initiative Program Management

- Field Measurements

- Tank Vapor Sampling and Analysis

- Solid Waste Screening

- Drum Headspace 


\section{Major Hanford Operations}

- Tank Waste Remediation System (TWRS) High Level Waste Management

- Spent Nuclear Fuel Storage

- Waste Management

- Liquid Effluent Retention facility

- Effluent Treatment Facility

- Evaporator

- Solid Waste Management

- Environmental Restoration Corporation (ERC)

- Site Soils Clean-up Environmental Restoration Disposal Facility (ERDF)

- Decontamination and Decommissioning 


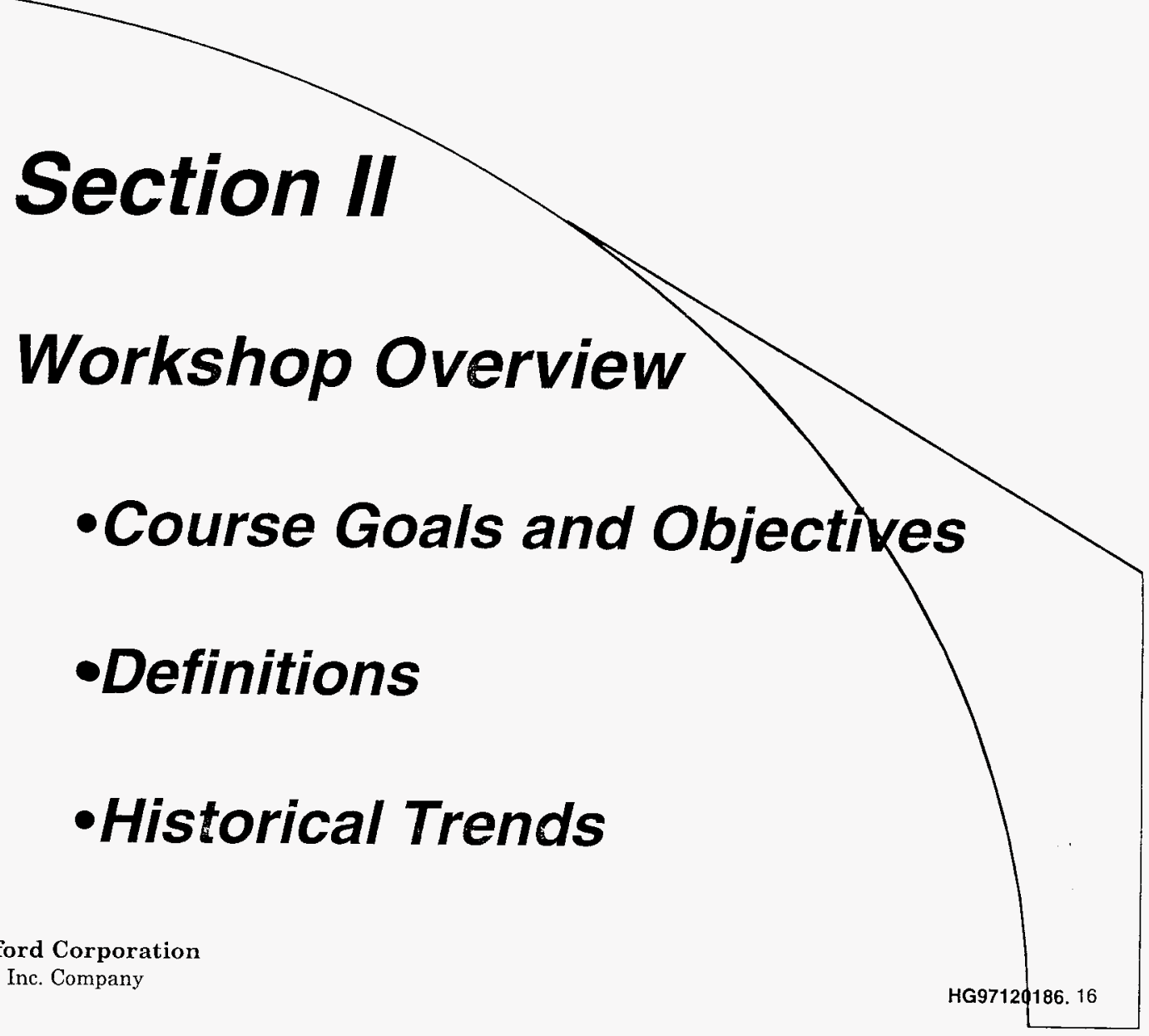




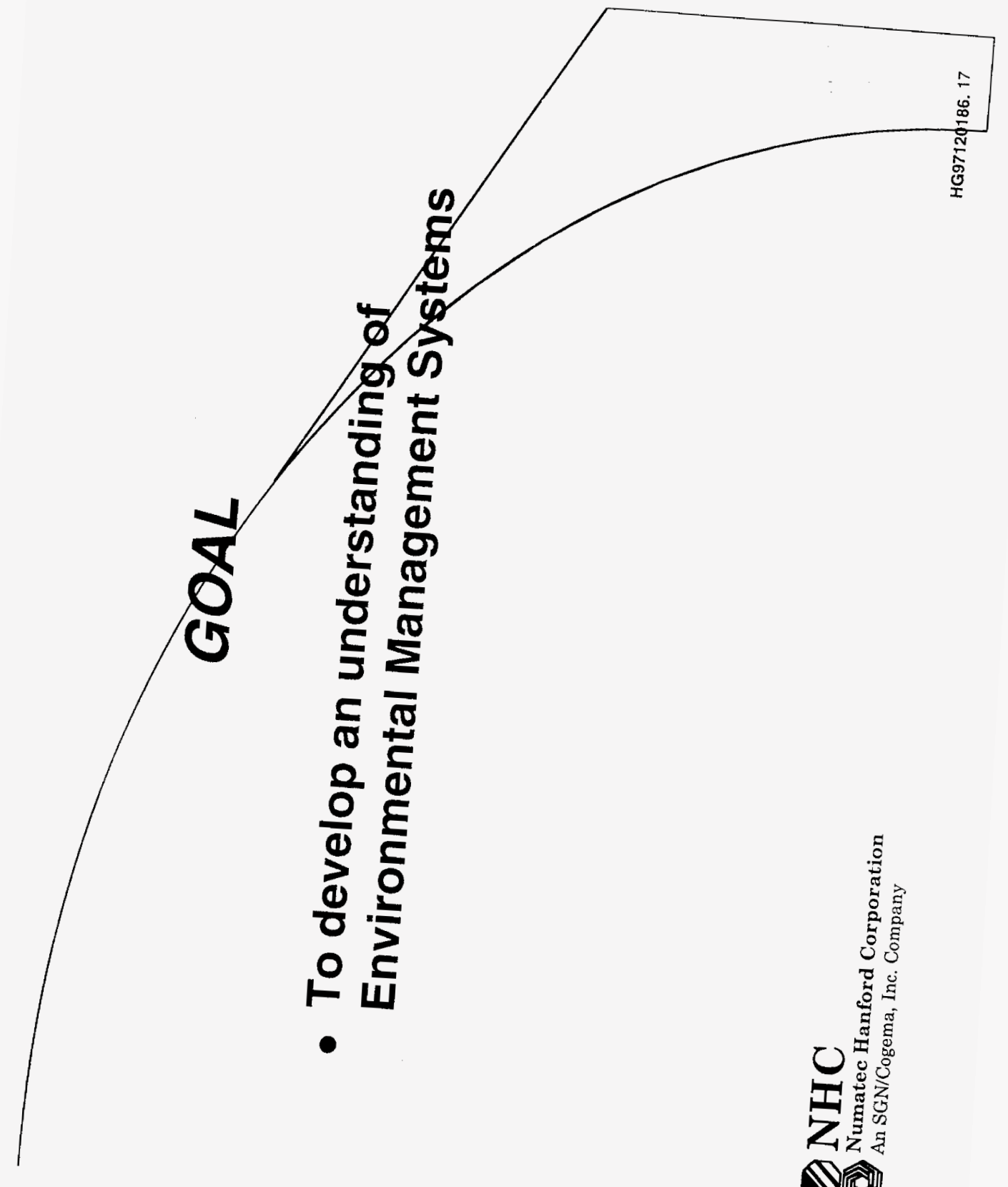


- Develop an awareness of uniform quality standards and how the standards maybe used

- Provide the framework for laboratoryprogram client agreement prior to sample collection and analysis

- Integrate the Jata Quality Objective Planning Proress 
- Organization

\section{Definitions}

- Company, corporation, firm, enterprise or institution, or part or combination thereof, whether incorporated or not, publid or private, that has its own functions and administration

- Note - For organizations with more that one pperating unit, a single operating unit may be defined as an organization

- Top Management

- An individual or group of individuals with executive responsibility for the organization 


\section{Defin}

- Surroundings in which an organzzation operates, including air, water, land hatural resources, flora, fauna, humans, and thelk interrelation

- Note - Sur oundings in this context from withip an organizati $n$ to the global system

- Environmen Łal management

- Those aspects of the overall management function (irsiuding planning) that determine and impler.ent the environmental policy 


\section{Definitions (continued)}

- Environmental Management System (EMS)

- That part of the overall management system which includes organizational structure, lanning activities, responsibilities, practices, procedure, processes, and resources for developing, implementing achieving, reviewing, and maintaining the environmental policy

- Environmental Management System Audit

- Systematic and documented verification process to objectively obtain and evaluate evidence to determine whether an organization's environmental management system conforms to the environmental management system audit criteria set by the organization, and communication of the results of this process to management 


\section{- Environmental Policy}

\section{(continued)}

- Statement by the organization of its intentions and principles in relation to its overall environmental performance which provides a framework for action and for setting of its environmental objectives and targets

- Environmental Aspect

- Element of an organization's activities, products, or services which can interact with the environment

- Note - A significant environmental aspect which has or can have a significant environmental impact 
- Environmental Impact

- Any change to the environment, whether adverse or beneficial, wholly or parthally resulting from an organization's activities, products, or services

- Environmental Objective

- Overall environmental goal, arising from the environmental policy, that an organization sets itself to achieve, and which is quantified where practicable 


\section{Definitions (continued) \\ - Environmental Target}

- Detailed performance requirements, quantified where practicable, applicable to the organization or parts thereof, that arises from the environmental objectives and that needs to be set and met in order to achieve those objectives

- Environmental Performance

- Measurable results of the EMS related to an organization's control of its environmental aspects, based on its environmental policy, objectives and targets 


\section{- Continual Improvement}

- Process of enhancing the environmental management system to achieve improvements in overall environmental performance in line with the organization's environmental policy

- Nonconformity

- The nonfullfillment of a specified 14001 requirement 


\section{Definitions (continued) \\ - Prevention of Pollution}

- Use of processes, practices, materials or products that avoid, reduce or control pollution, which may include recycling, treatment, process changes, control mechanisms, efficient use of respurces and material substitution

- Note - The potential benefits of prevention of pollution include the reduction of adverse environmentar impacts, improved efficiency and reduced costs

- Interested Party

- Individual or group concerned with or affected by the environmental performance of an organization 


\section{Definitions (continued)}

- Pollution Prevention

- The use of materials, processes, pr practices that reduce or eliminate the creation of pellutants or wastes at the source; it includes practices thateduce the use of hazardous materials, energy, water or athex resources, and practices that protect naturat resources through conservation or more efficient use

- Prevention Action

- Steps taken to identify and avoid incidents potentially leading to a nonconformity

- Corrective Action

- An action taken to eliminate the causes of an existing nonconformity, defect, or other undesirable situation in order to prevent recurrence 


\section{Reactive}

- Compliance Mode

- End of pipe control

- Separate environmental management functions

- Emphasis on remediation 


\section{Proactive}

- Prevention mode

- Pollution prevention

- Environmental management functions integrated with operations

- EMS approach developing

Systems Approach 


\section{Management System Approach}

- EMS

- Integration of environmental ethics throughout organization

- Integration of environmental business activities

- Management systems

- Accounting Systems

- International recognition through certification (an option) 


\section{Management Systems Development Drivers}

- Laws and Regulations

- U.S. Environmental Protection Agency (EPA) Initiatives

- Industry Standards

- Chemical Manufactures Association

- Occupational Safety and Health Administration(OSHA) Voluntary Protection Program

- Others

- Other Standards

- International Standards Organization (ISO) 9000

- British Standards (BS) 7750

- ISO 14000

- Hanford Analytical Services Quality Assurance Plan 


\section{Section III}

\section{Management Process}

-Total Quality Fitness Revie
-10-Step Sample and Data Management 


\section{Total Quality Fitness Review}

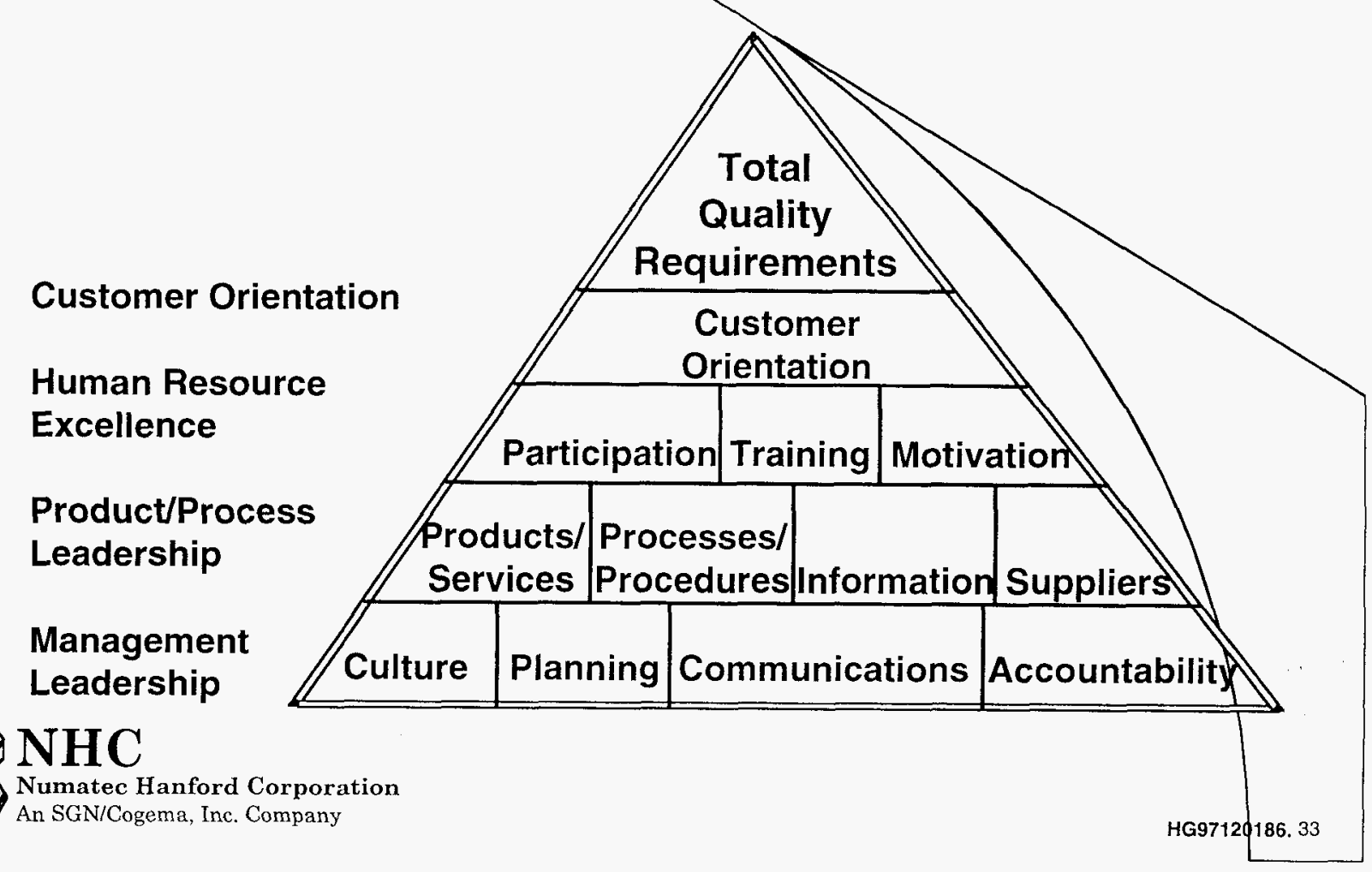




\section{Management Process Flow}
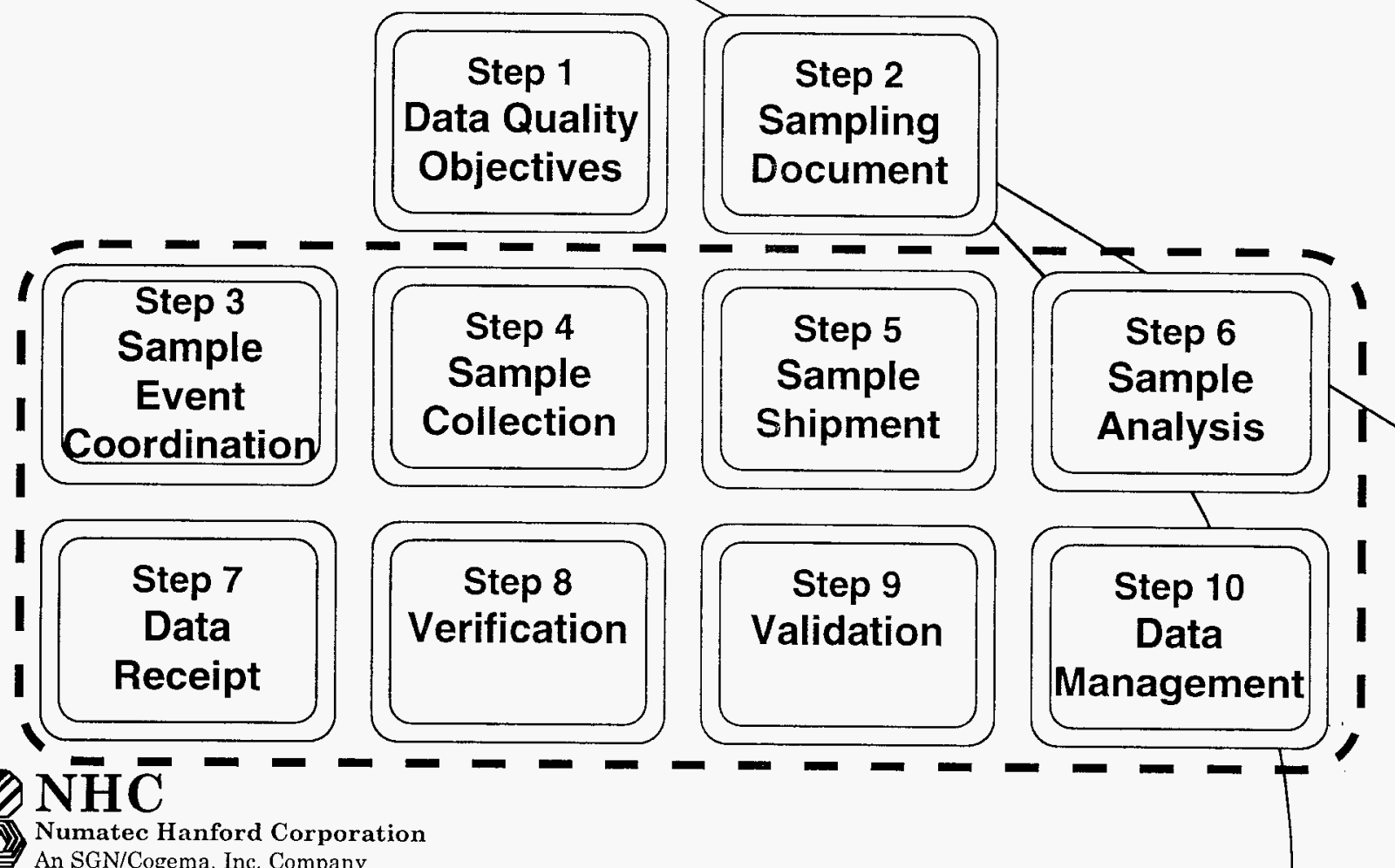


\section{Management Process Flow}
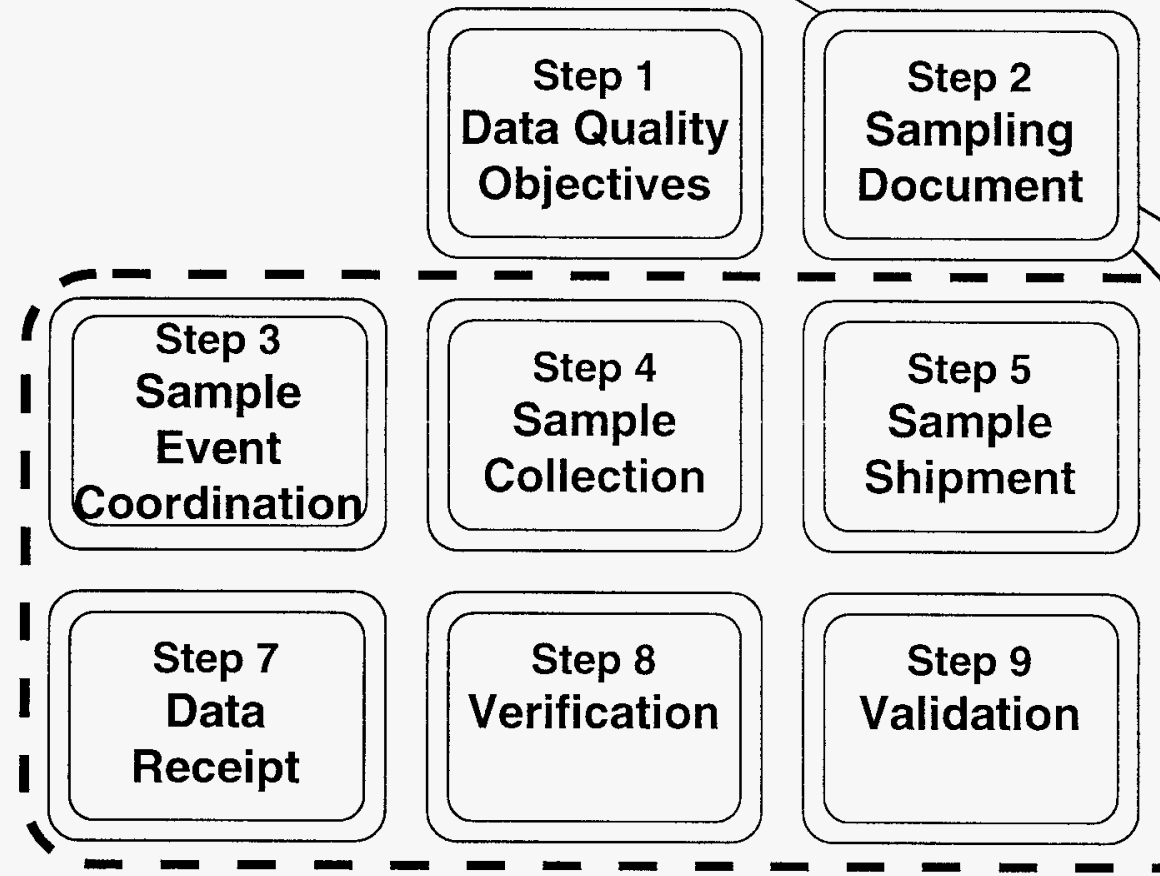


\section{Data Quality Objectives (DQO)}

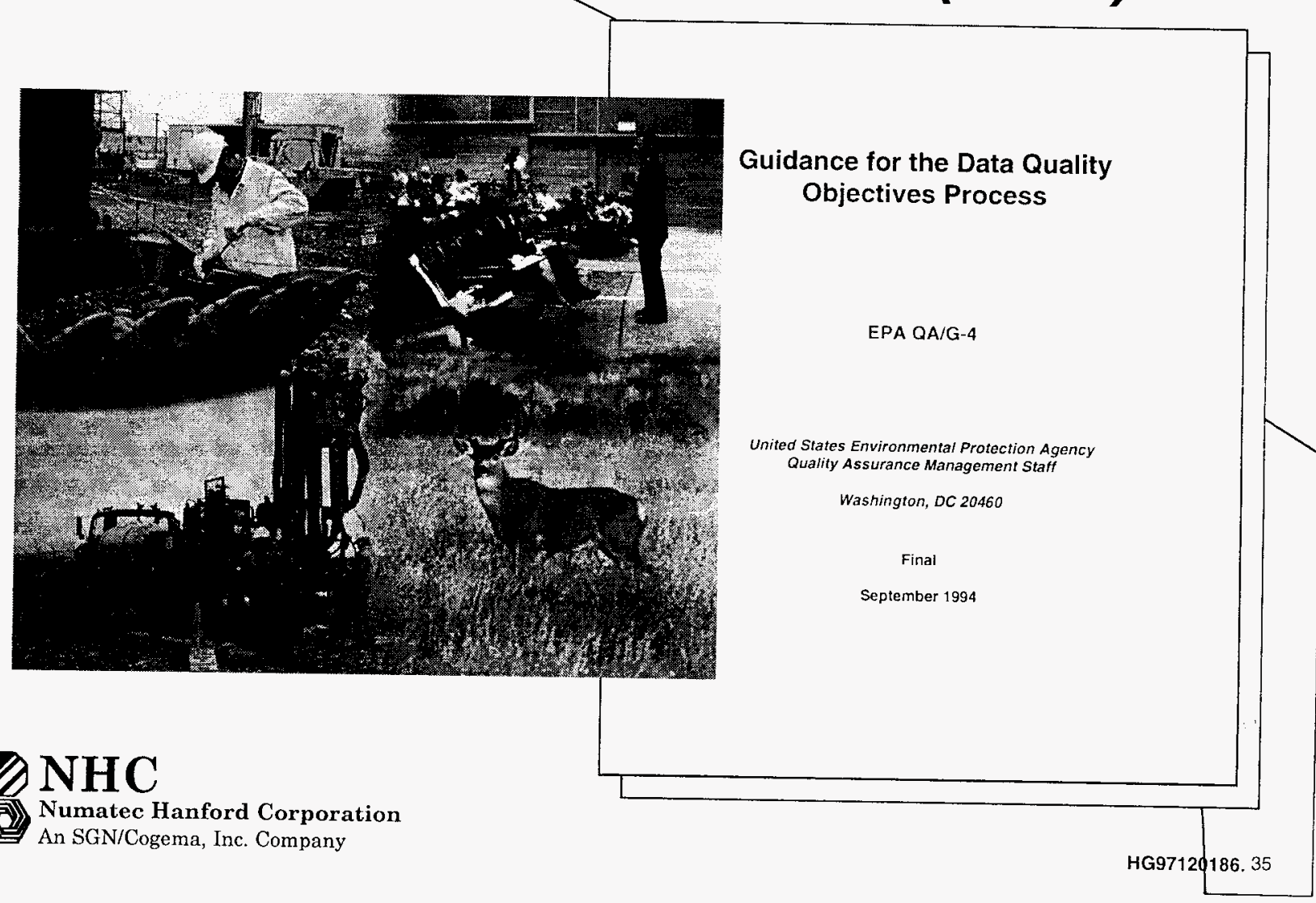




\section{Da}

Purpose

- To implement the EPAs 7-Step Data Quality Objectives (DQO) Process 'to assure that the type quantity and quality of environmental data used in decision making will be appropriate for the intended application." 


\section{Data Quality Objectives Process}
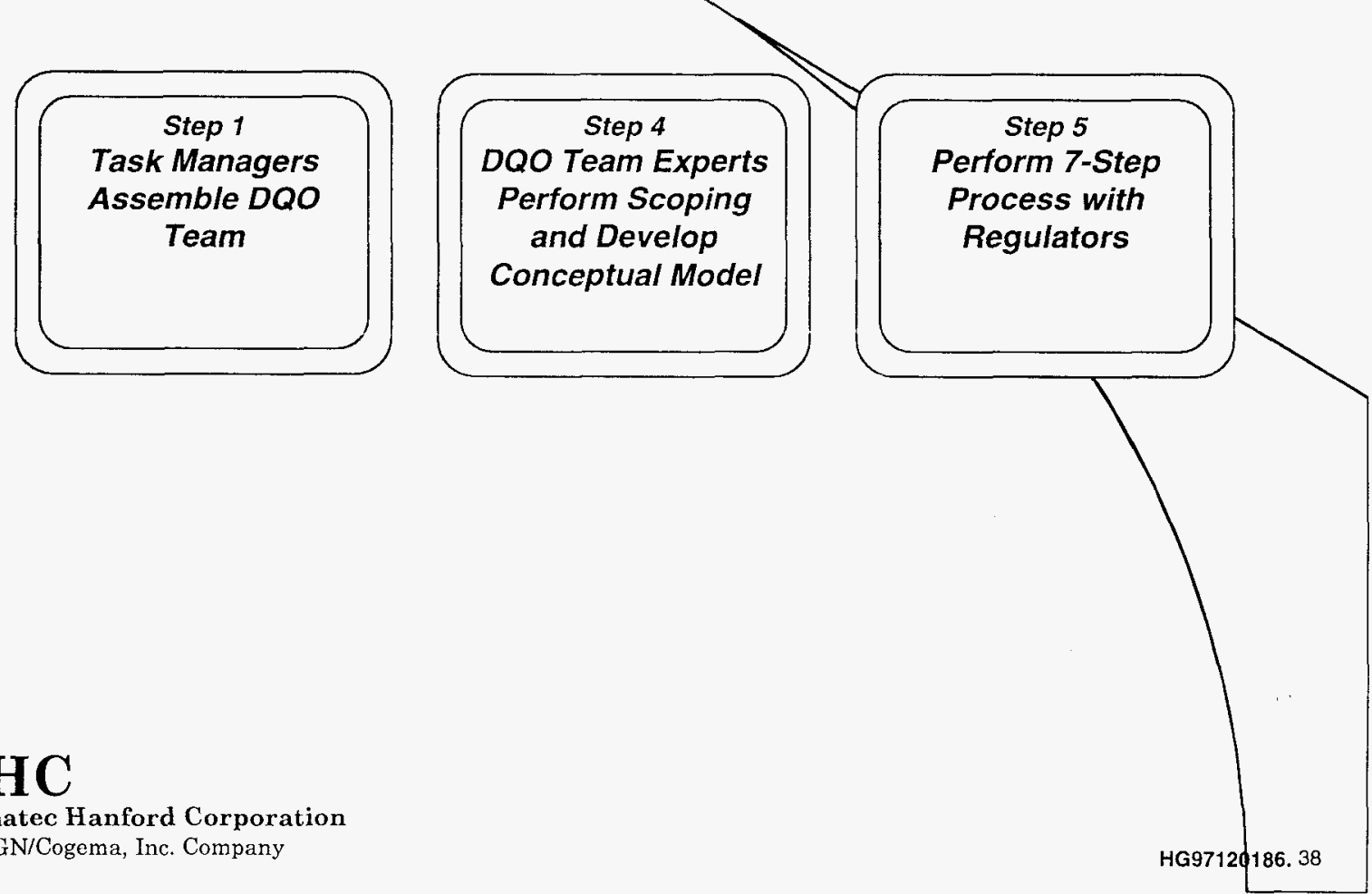


\section{Data Quality Objectives Process}
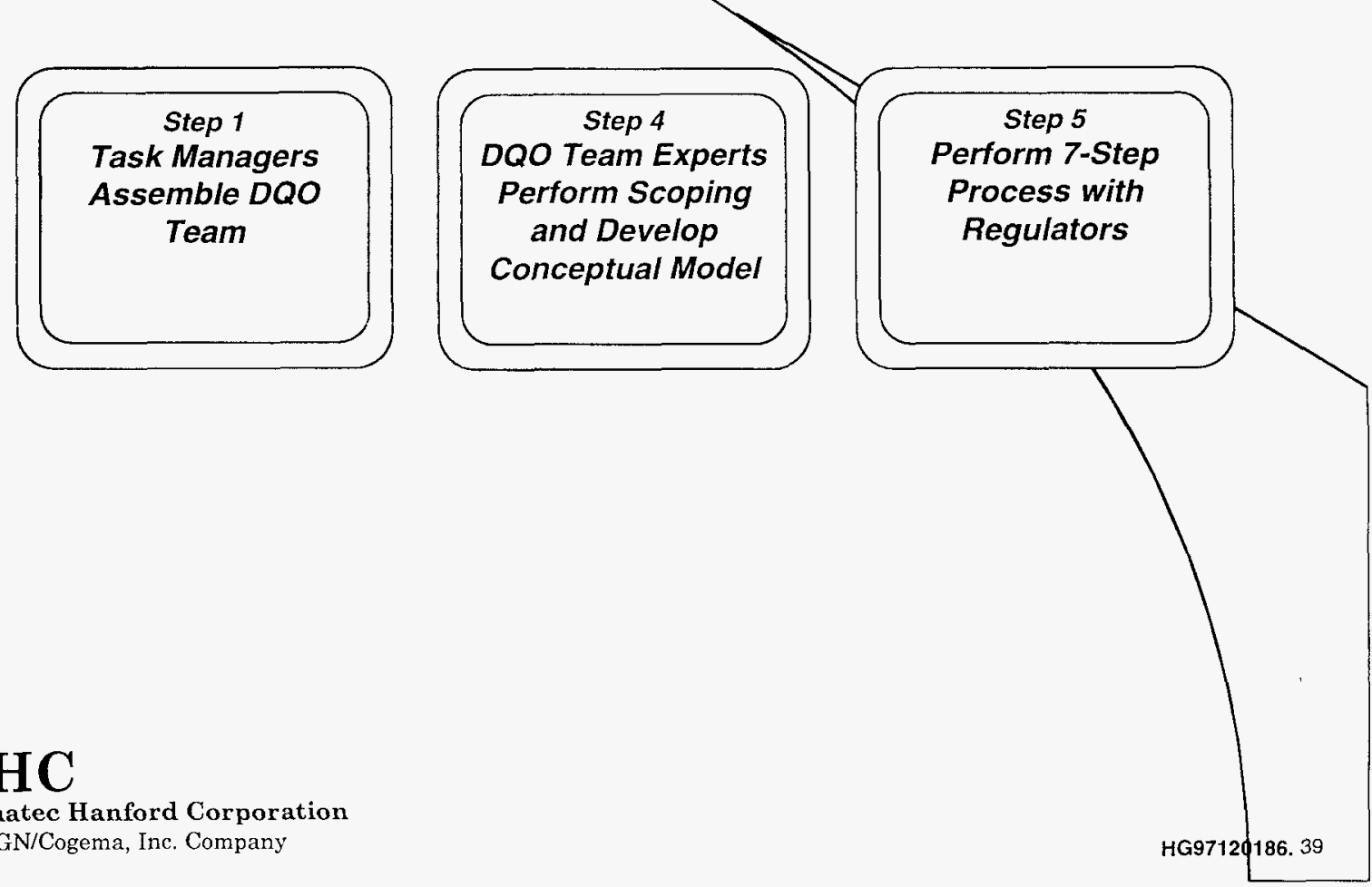


\section{Data Quality Objectives (Continued)}

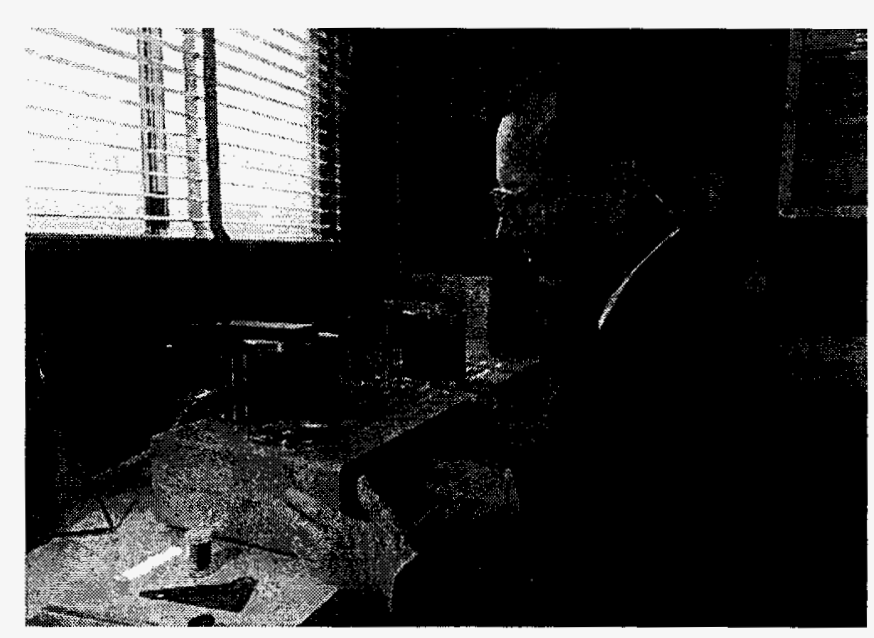

- Task managers assemble team

- Scientists

- Engineers

- Analysts

- Statisticians

- Risk Assessors

- Others 


\section{Data Quality Objectives (Continued)}

Process Description (contipued)

- Team reviews existing data (some electronically from databases)

- Data analyzed

- Conceptual model built

- Regulators, U.S. Department of Energy (DOE), and Team perform EPAs 7-Step Process using 3rd party facilitation

- DQO Process Summary Report is prepared and issued 


\section{Data Quality Objectives (Continued)}

\section{Process Strengths}

- DOE and Contractor are committed ta DQO Process

- Significant cost/schedule savings can be achieved without jeopardizing technical decisions 


\section{Data Quality Objectives (Continued)}

Process Weaknesses

- New system

- Requires acceptance and training

- Requires more up front resources

- Time

- Cost

- Labor

- DQO Process Summary Report format not standardized

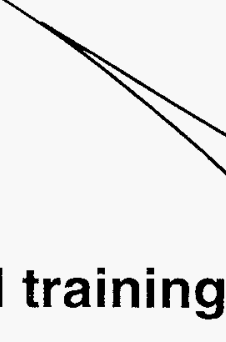




\section{Data Quality Objectives Process}
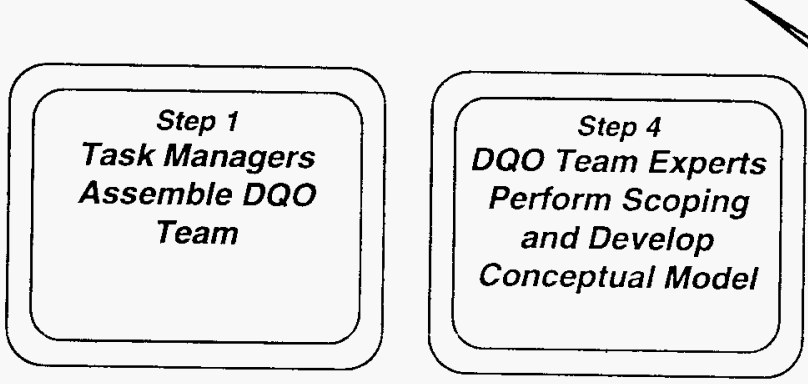

- Database information

- Site visits

- Interviews

- Literature

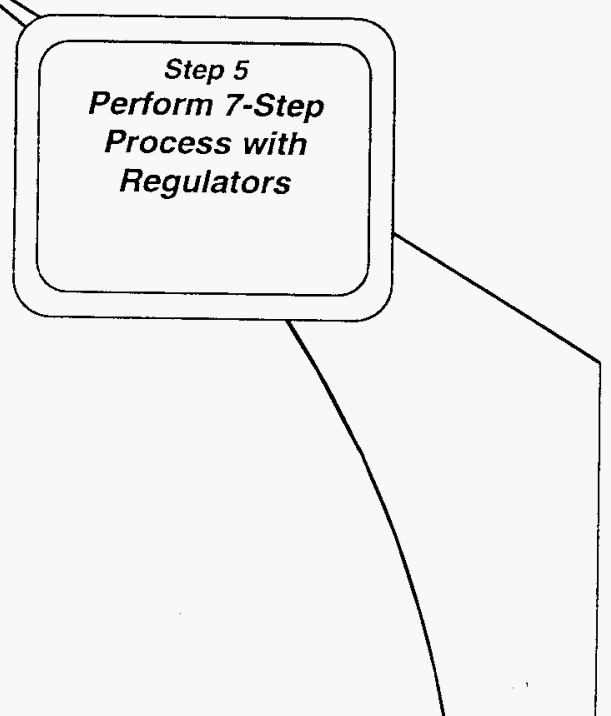




\section{Data Quality Objectives Process}
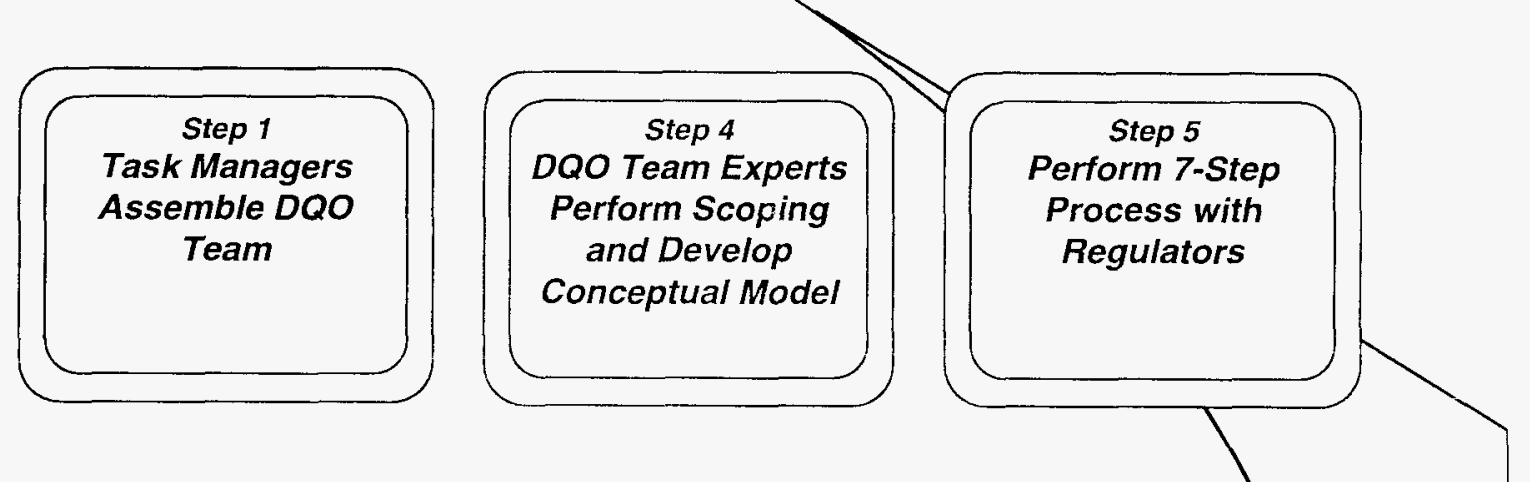

- Prepare DQO Process Summary Report 


\section{The Vapor Monitoring "Database"}

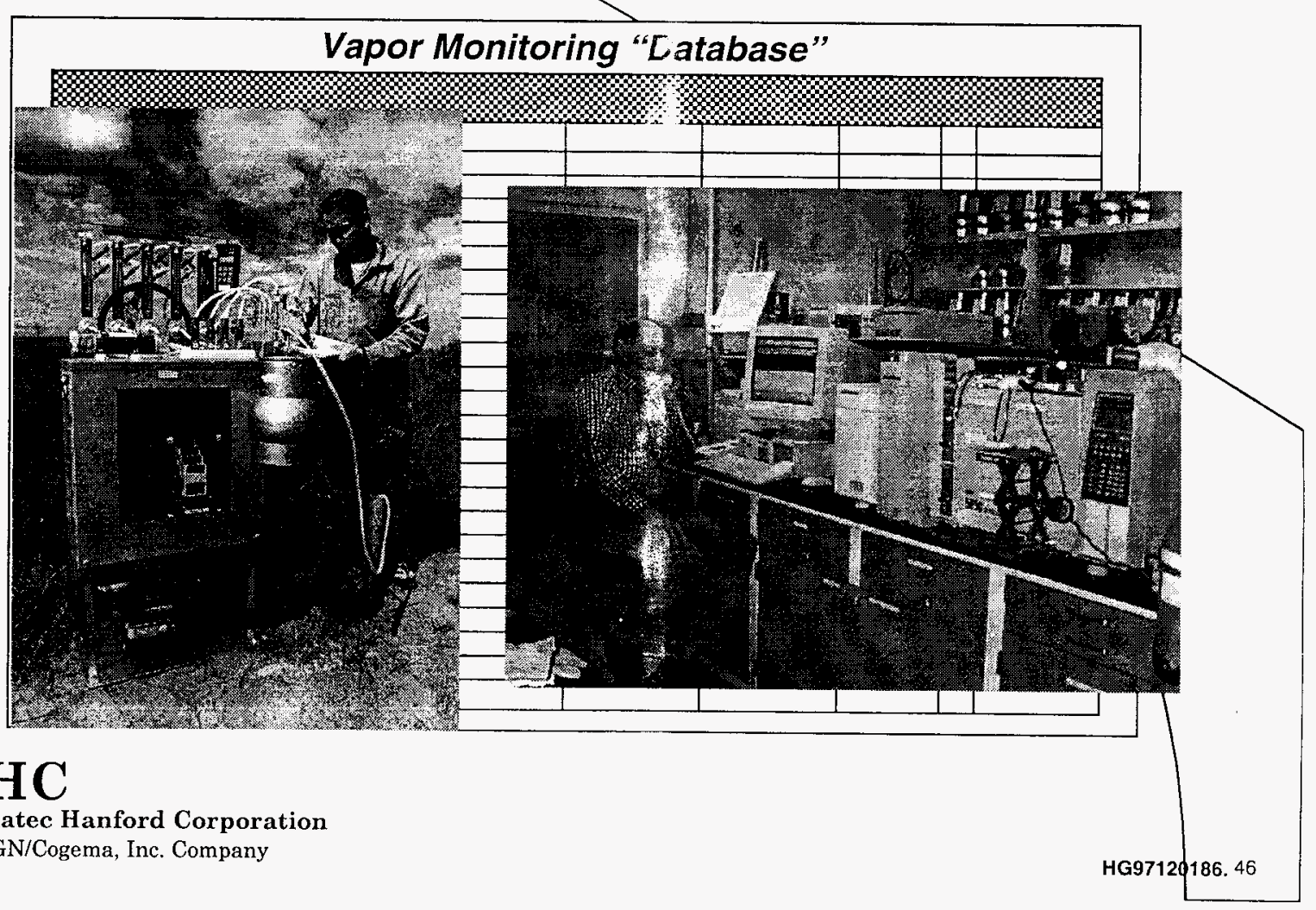




\section{The Vapor Monitoring "Database"}

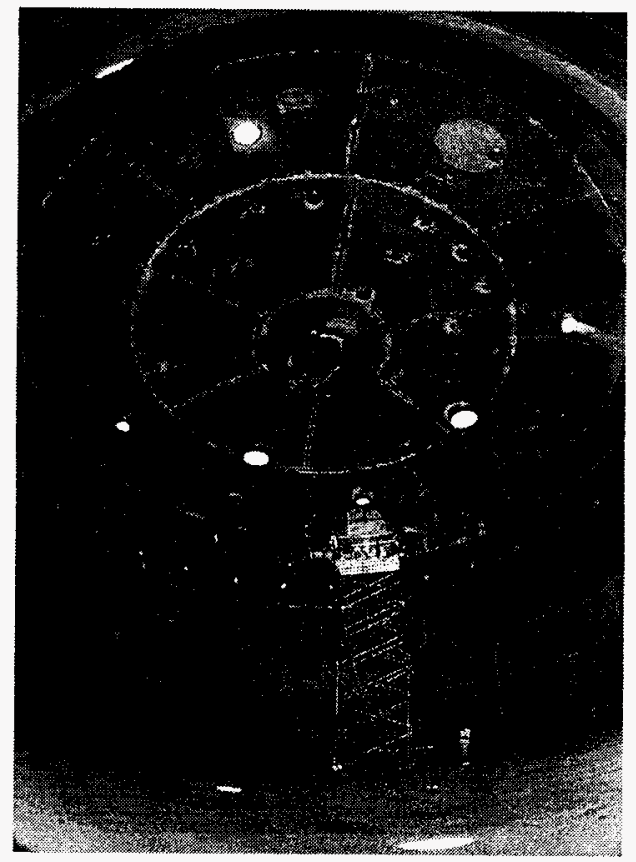

Purpose

- To provide the DQO team and task managers with a "Database" to evaluate the effectiveness of using vapor monitoring to meet their analysis needs 
The Vapor Monitoring "Database" Process

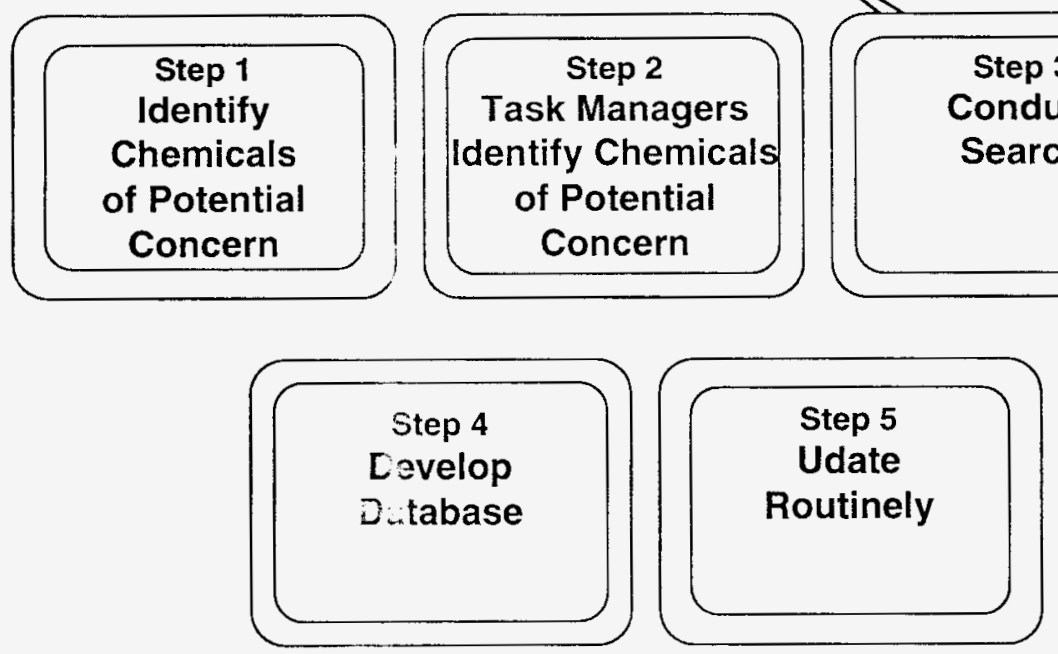




\section{The Vapor Monitoring "Database"}

(contin

Process Description
- Development of "Database"

- Identify chemicals of potential concern

- Identify Task Managers potential needs

- Conduct search of available methods

- Literature

- Networking

- Etc. 


\section{The Vapor Monitoring "Database"}

(continued)

\section{Process Description (continued)}

- Development of "Database"

- Develop "Database" format

- Input to spread sheet program

- Update routinely 


\section{The Vapor Monitoring "Database"}

(continued)

Process Strengths

- Listing of all pertinent specifications for available vapor monitoring methods are centralized and available to DQO Teams and Task Managers

- Database promotes use of low cost and rapid analysis methods 


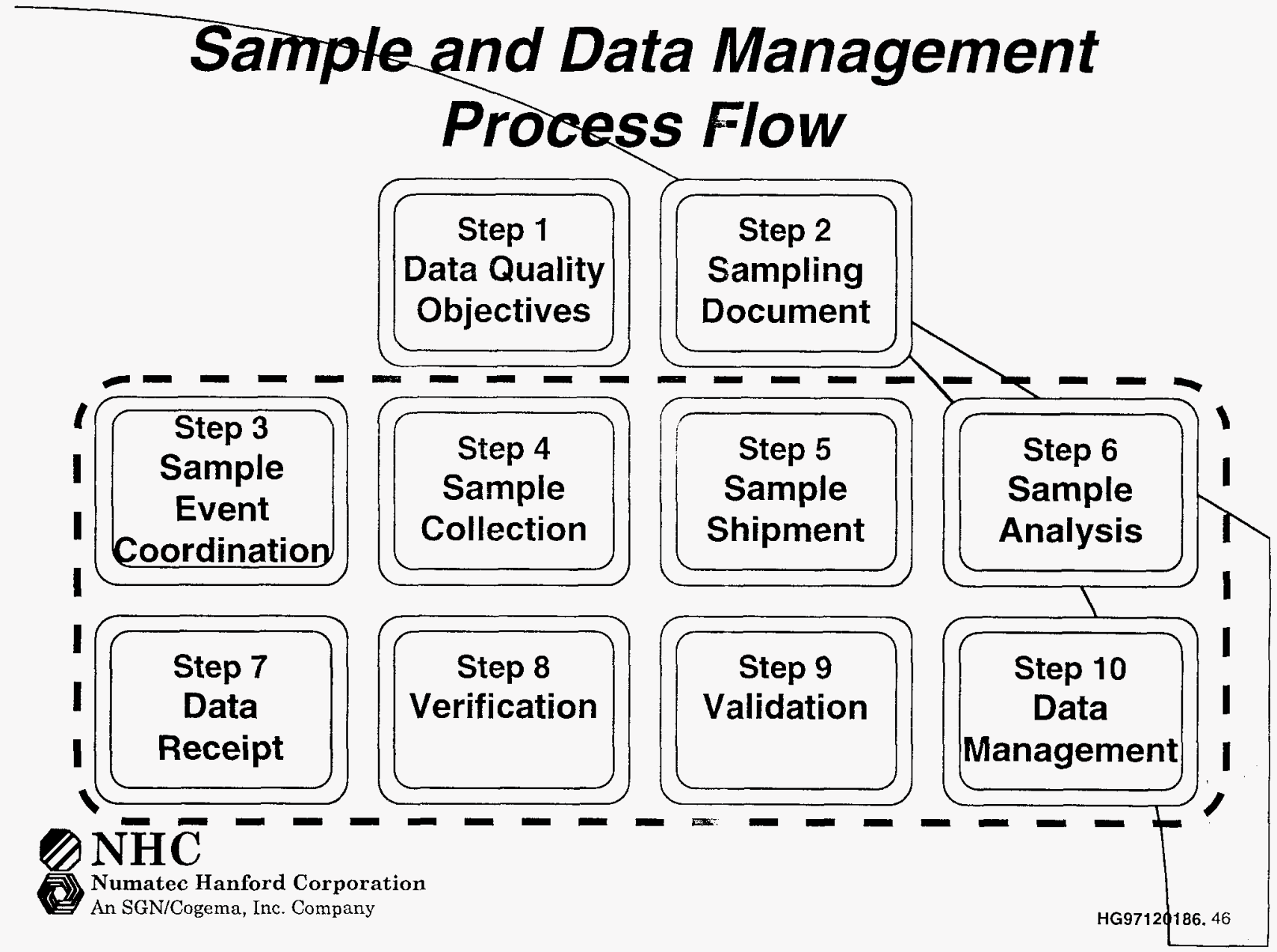




\section{Sampling Documents}

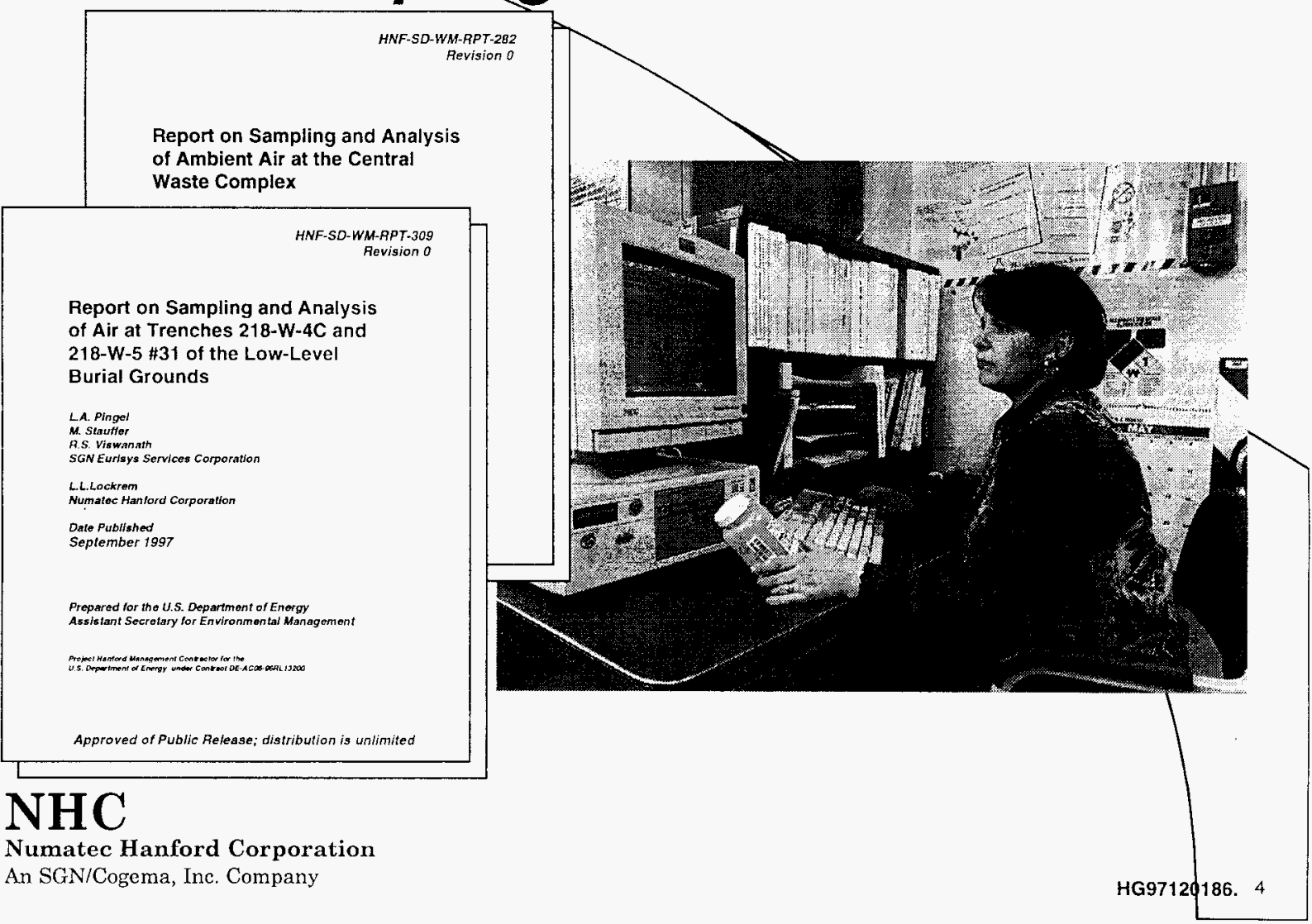




\section{Sam}

\section{Purpose}

- To document the detailed instructions and controls needed for performing sampling and analytical services to meet Task Manager and regulator expectations 


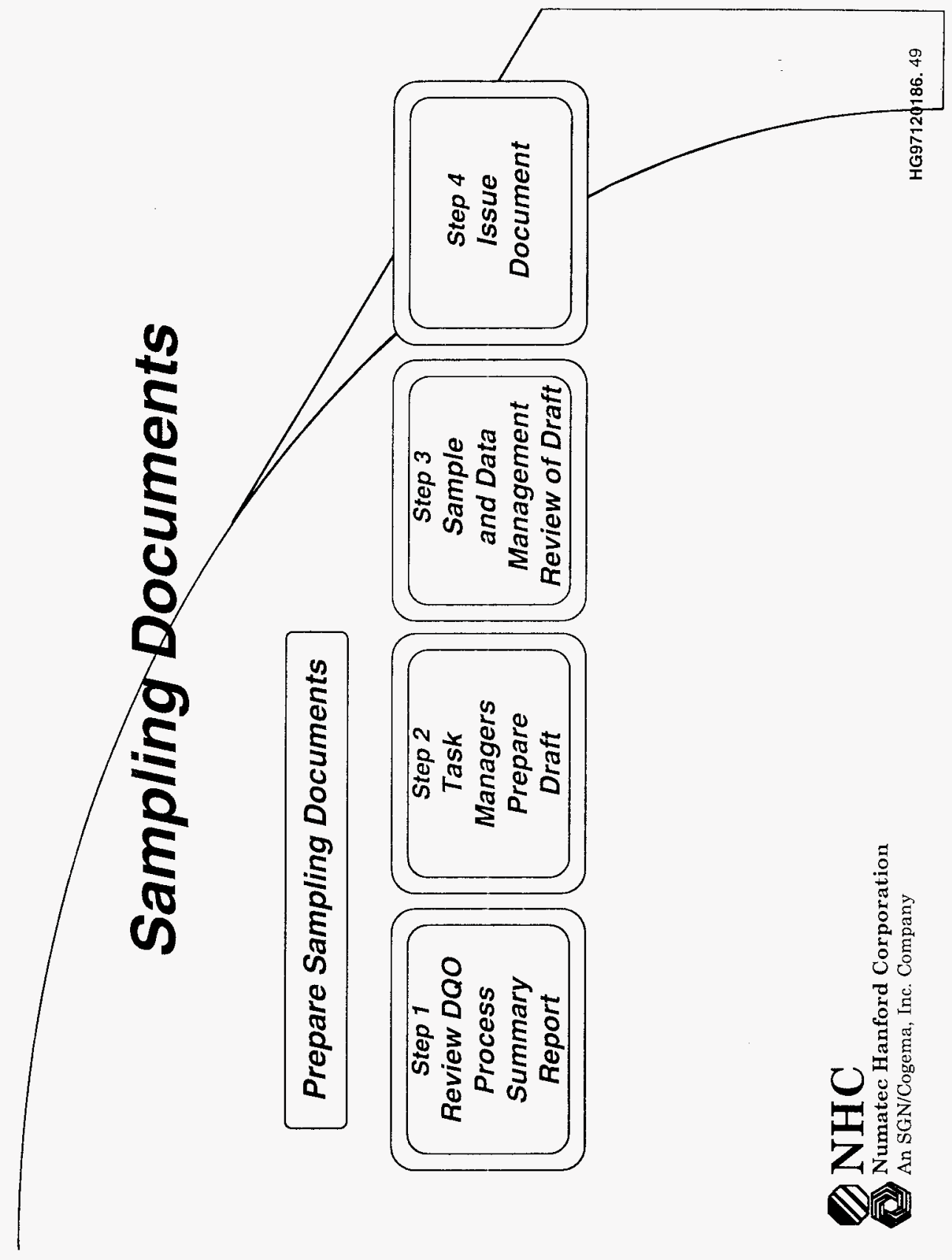




\section{Sampling Documents (continued)}

\section{Process Description}

- Documents drafted based on DQQ Process Summary Report

- Documents prepared by Task Managers

- Document reviewed by sample and data management

- Approved dozument used for input to services requested from Task Managers 


\section{Sampling Documents (continued)}

\section{Process Strengths}

- Documents reviewed and approved by Task Managers, DOE, and Regulators

Process Weaknesses

- New document template is desirable
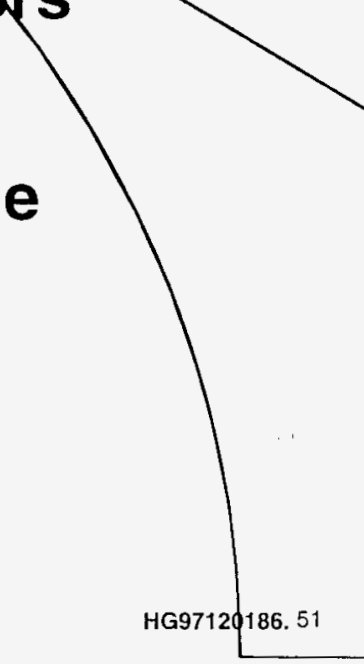


\section{Sample and Data Management Process Flow}

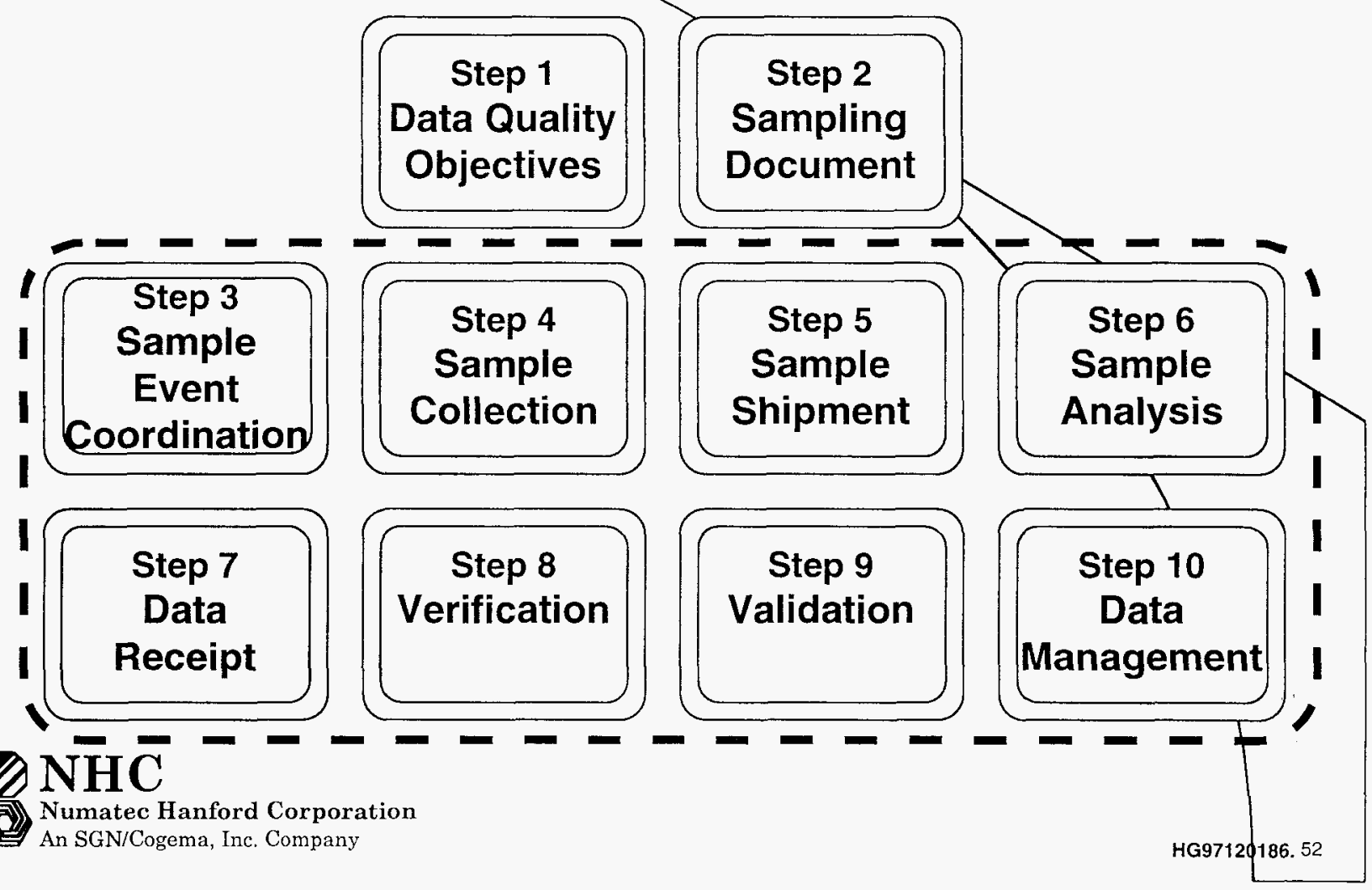




\section{Sample Event Coordination}

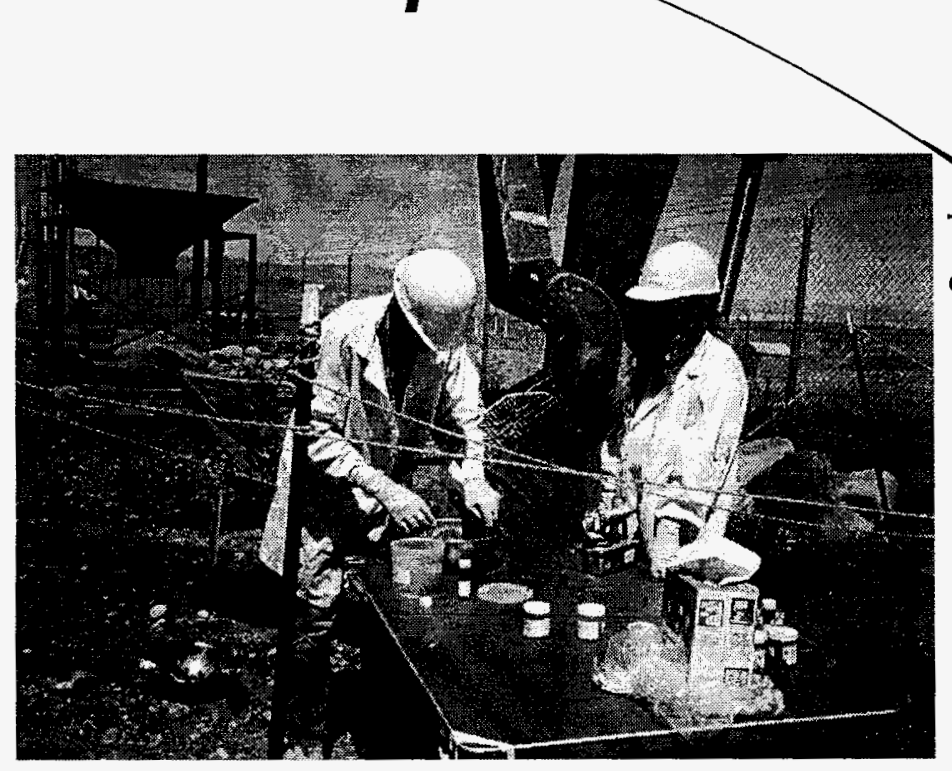

Rurpose

- Based on requikements from approved sampling documents, sample event coordination establishes a foundation for field sampling and analytical work 


\section{Sample Event Coordination Process}
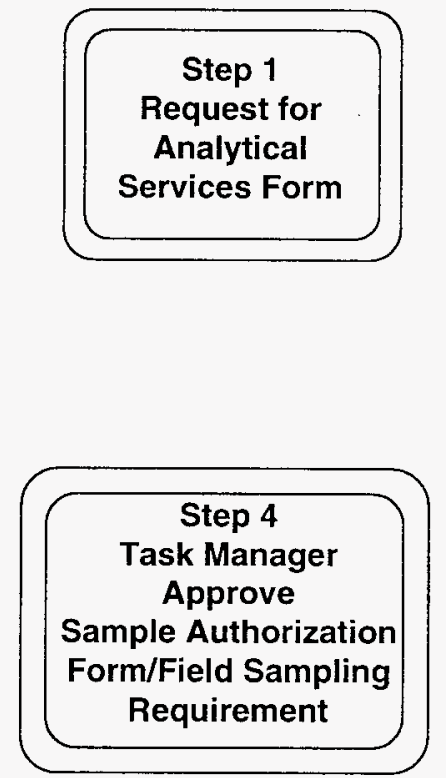

NHC

Numatec Hanford Corporation An SGN/Cogema, Inc. Company
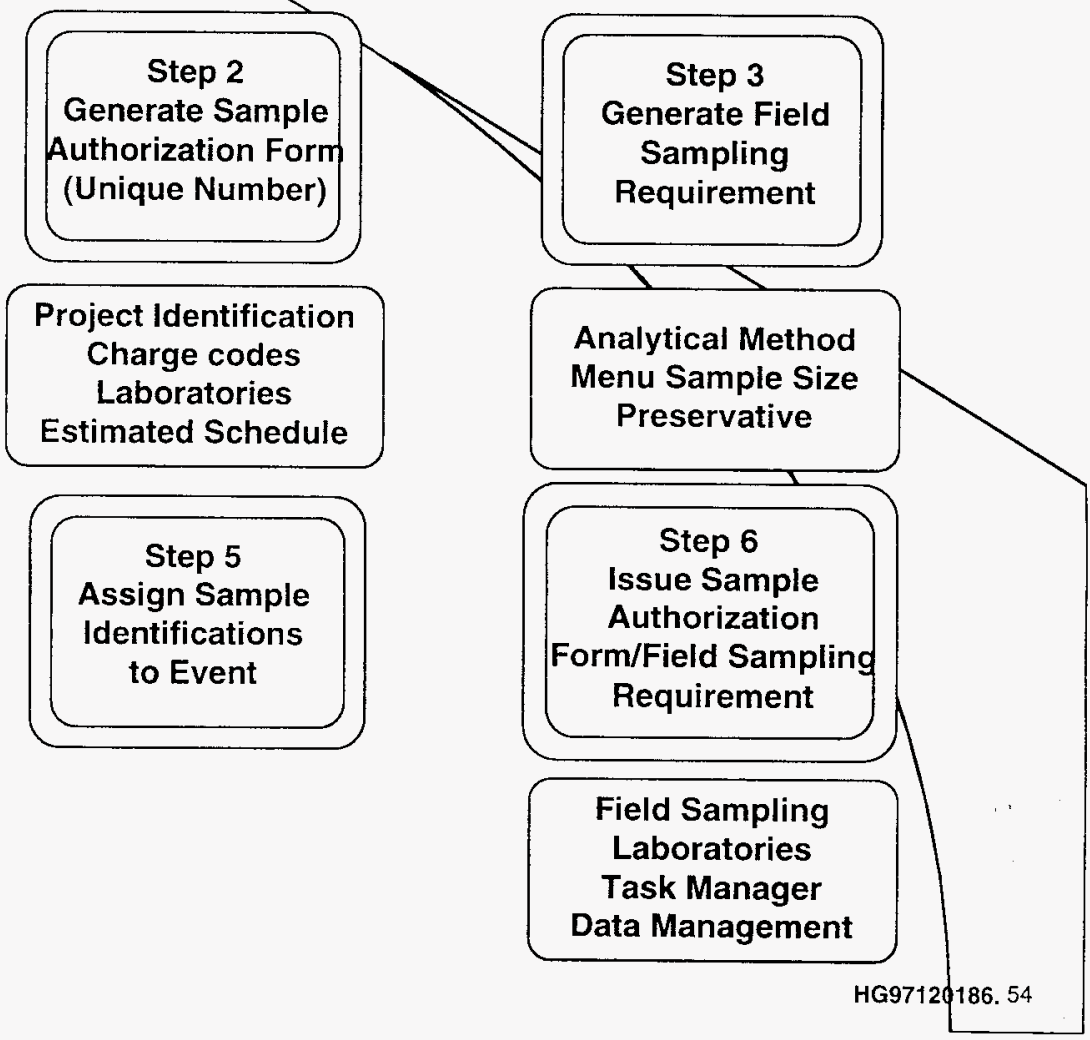


\section{Sample Event Coordination}

(continured)

\section{Process Description}

- Request for Analytical Services

- Provided by Task Manager

- Communicates task background

- Defines analytical requirements based on approved Sampling Document 


\section{Sample Event Coordination \\ (continued)}

Process Description (continued)

- Sample Authorization Form/Fierd Sampling Requirements

- Prepared based on information from Request for Analytical Services"

- Unique number assigned to each sampling event

- Pool of sample numbers form database librayy assigned to event

- Event identification linked through entire process and across database systems 


\section{Sample Event Coordination}

(continued)

\section{Process Description (continued)}

- Sample Authorization Form/Field Sampling Requirements

- Establish menu of analytical methods, sample sizes, preservation requirements

- Approved by Task Managers prior to issuance

- Electronic distribution to Task Manager, samplers, analytical resources

- Closed after confirmed completion of event 


\section{Sample Event Coordination}

(continued)

Process Strengths

- Integrated event identification ackoss process

Process Weaknesses

- Lack of integration with sample tracking systems 


\section{Sample and Data Management Process Flow}

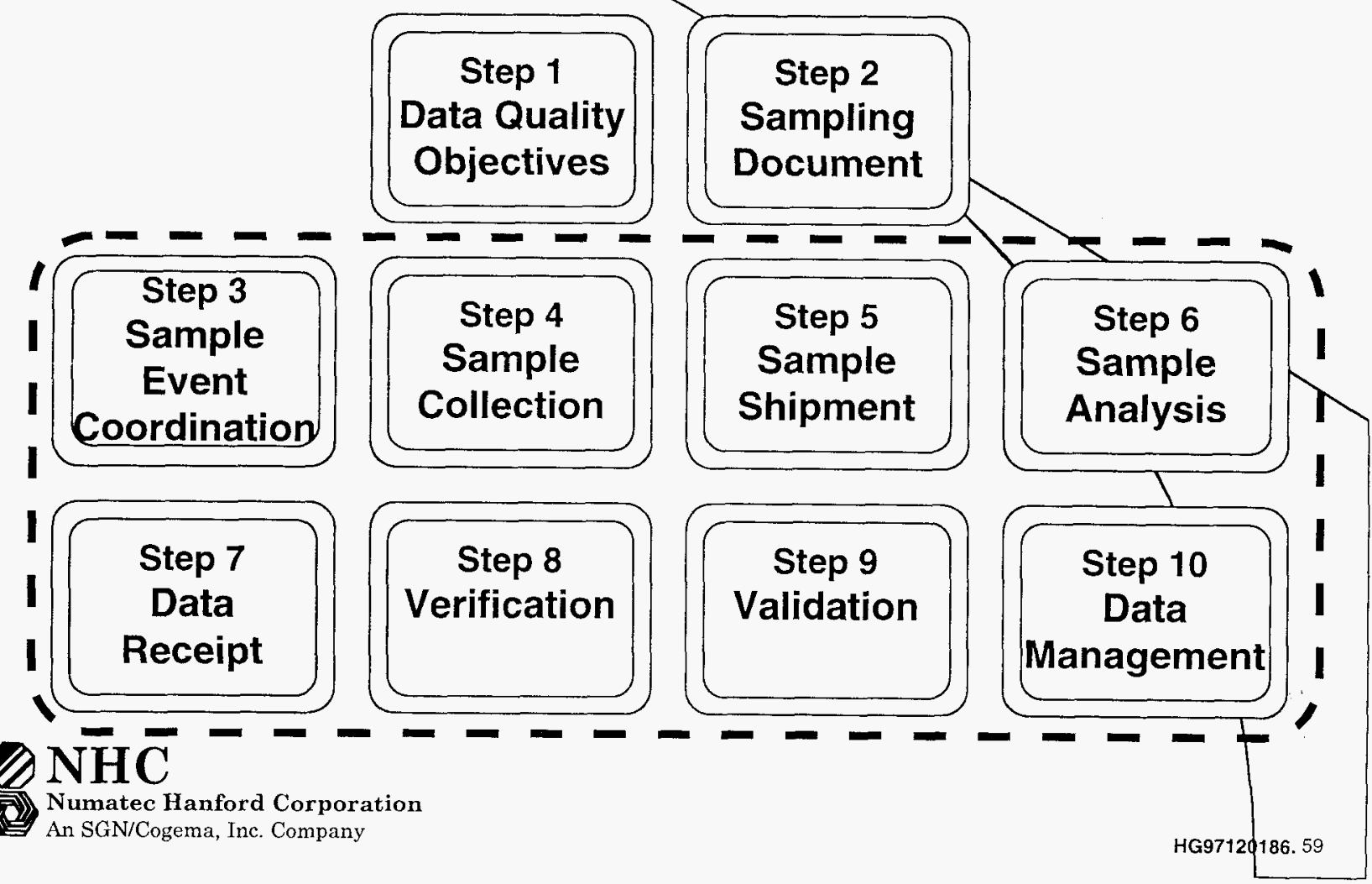




\section{Sample Collection and Shipment}

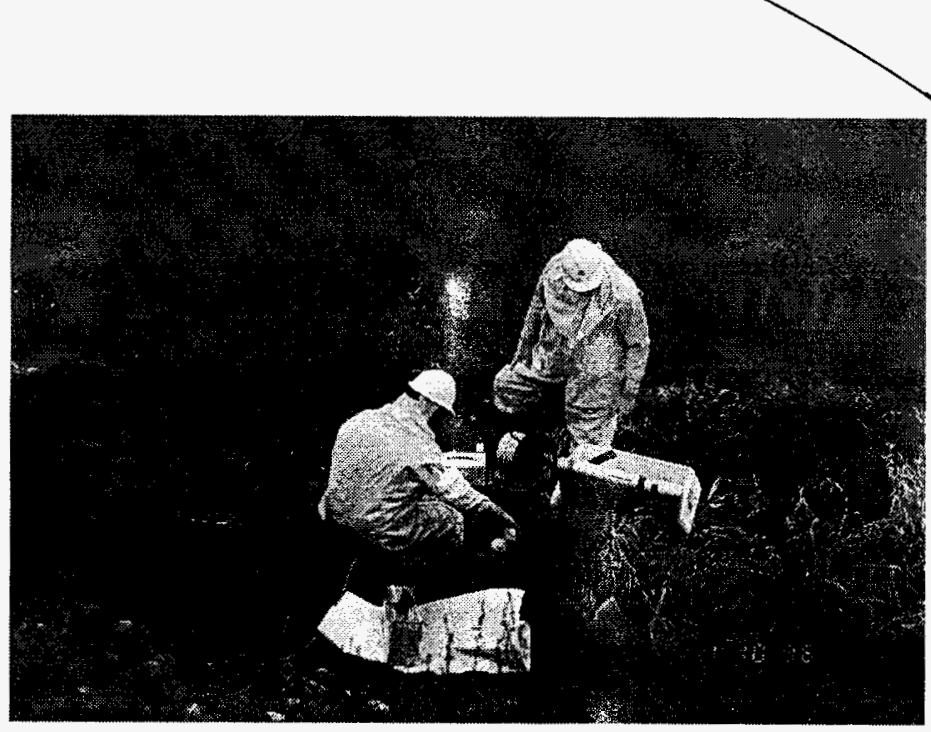

Rurpose

- Tacollect, describe, package, and ship samples to meet task managers approved sampling documents. To provide summary of activities to task managers on a routine basis 


\section{Sample Collection and Shipment Process}

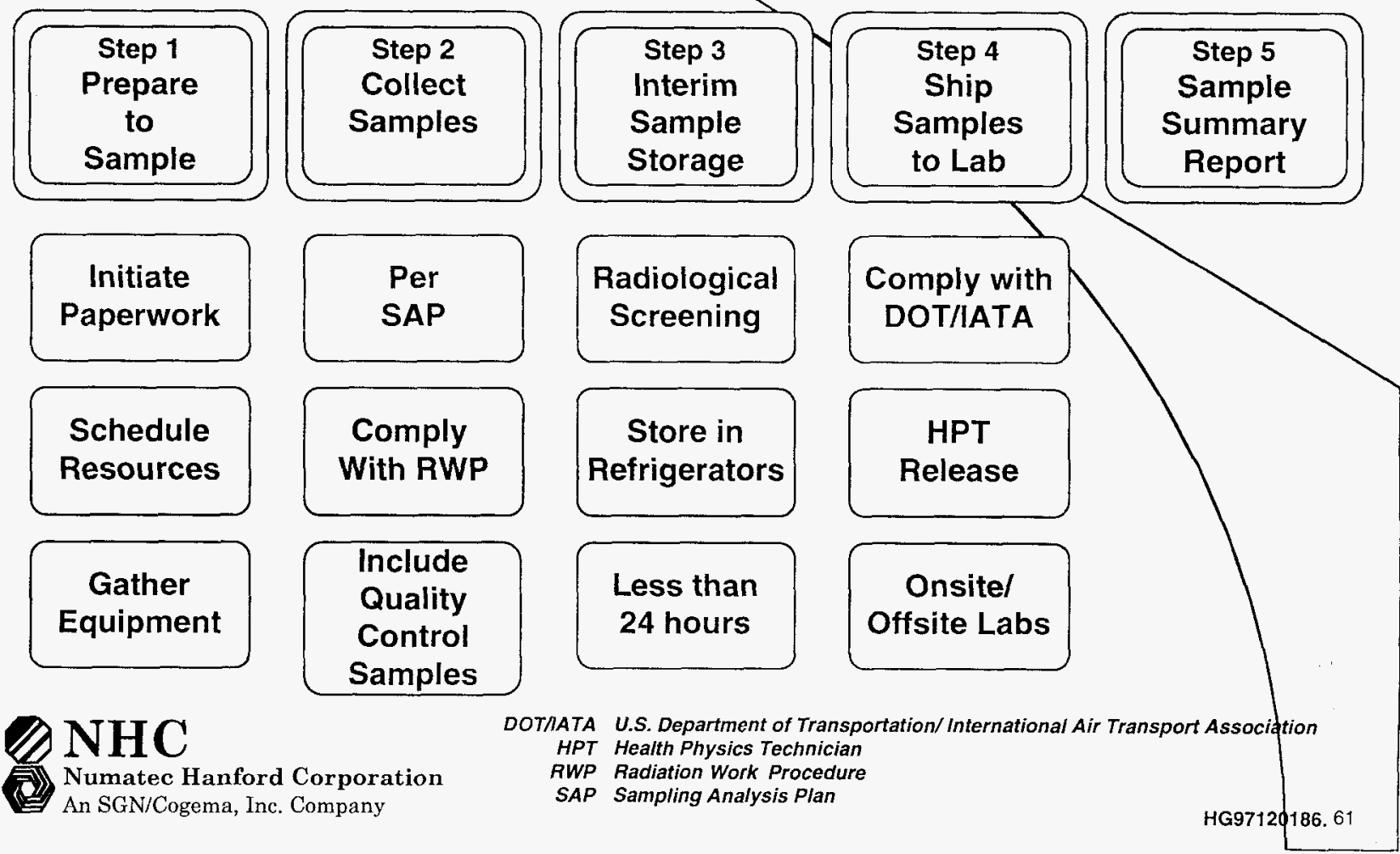




\section{Sample Collection and Shipment}

(continued)

\section{Process Description}

- Preparations

- Block of unique sample numbers issued for the task

- Information on the Sample Authorization Form used to prepare paperwork and sample bottle sets 


\section{Sample Collection and Shipment}

(continued)

\section{Process Description (continued}

- Preparations (continued)

- Resources scheduled, including personnel and equipment

- Databases are used to prepare for vapor sampling 


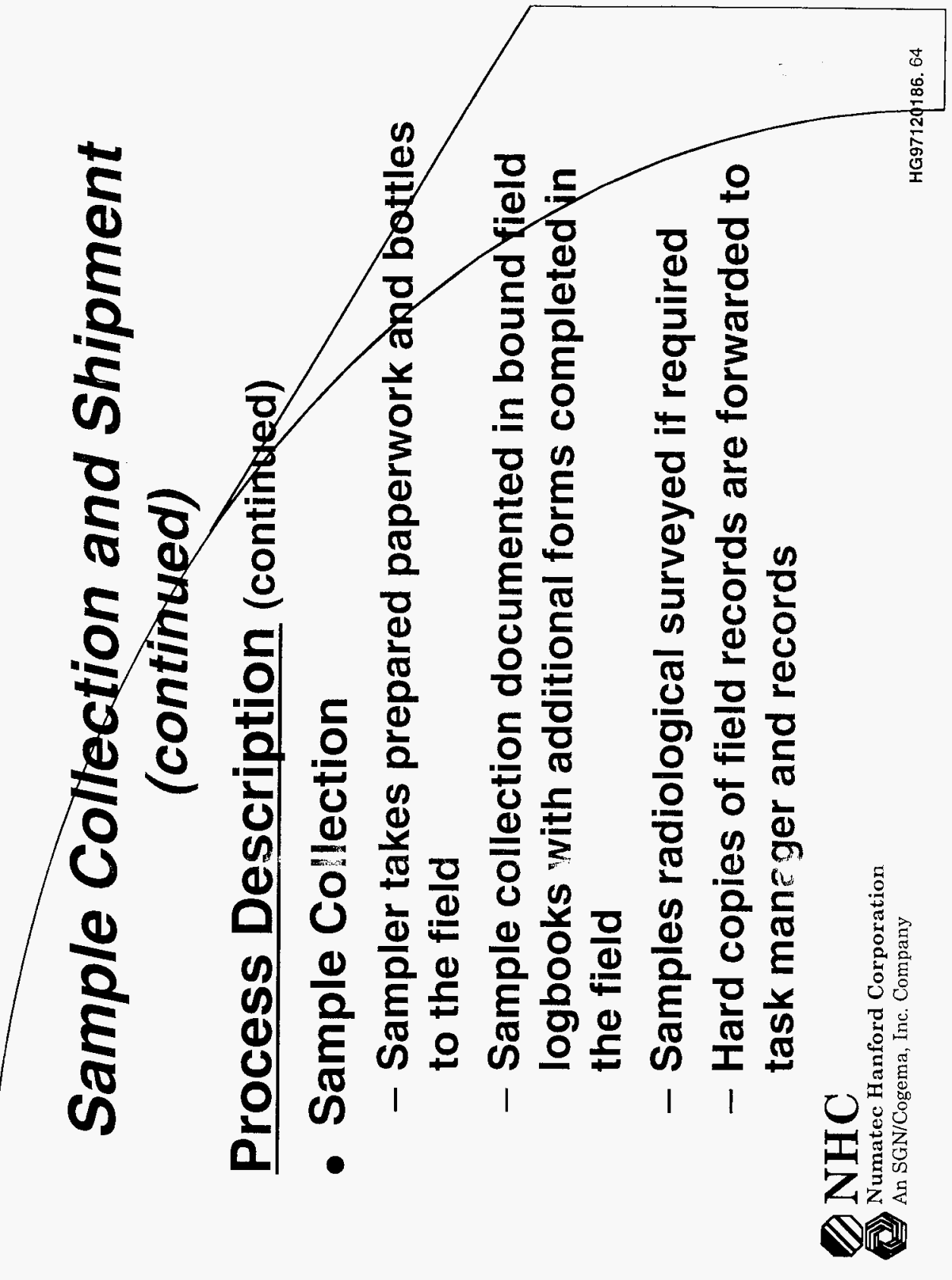




\section{Sample Collection and Shipment}

(continued)

Process Description (continued)

- Interim Sample Storage

- Samples delivered to sample storage facility and placed in refrigerators until overnight radiological screening is completed

- Historical information in databases used to determine if screening required

- Hard copy sample check-in and temperature logs maintained 


\section{Sample Collection and Shipment}

(continued)

Process Description (continued)

- Ship Samp'es to Lab

- Receive fax of total a tivity results

- Prepare shipping pa. erwork

- Package samples

- Hand carry to on site or local labs; ship by ajr to off site labs

- Copies of paperwork faxed to sample management to initia e sample tracking 


\section{Sample Collection and Shipment}

(continued)

Process Description (continued

- Sample Summary Report

- Field information related to sampling eyent transmitted to task manager, sample management and data management

- Connects the field data with the analytical data

- Hard copy placed in project file 


\section{Sample Collection and Shipment}

(continued)

\section{Process Strengths}

- Sample summary report is excedtent project deliverable

- Using historical data to make decisions for radiological controls has eliminated total activity analysis for about $75 \%$ vapor samples

- The process adequately supports the sample and data management process 


\section{Sample Collection and Shipment}

(continued)

Process Weaknesses

- No integrated sample schedule for activities

- No prioritization of sampling tasks vxhen schedules conflict - Everyone's task is a priority!

- Duplication of effort in generating, transmitting, and filing copies of paperwork 


\section{Sample and Data Management Process}

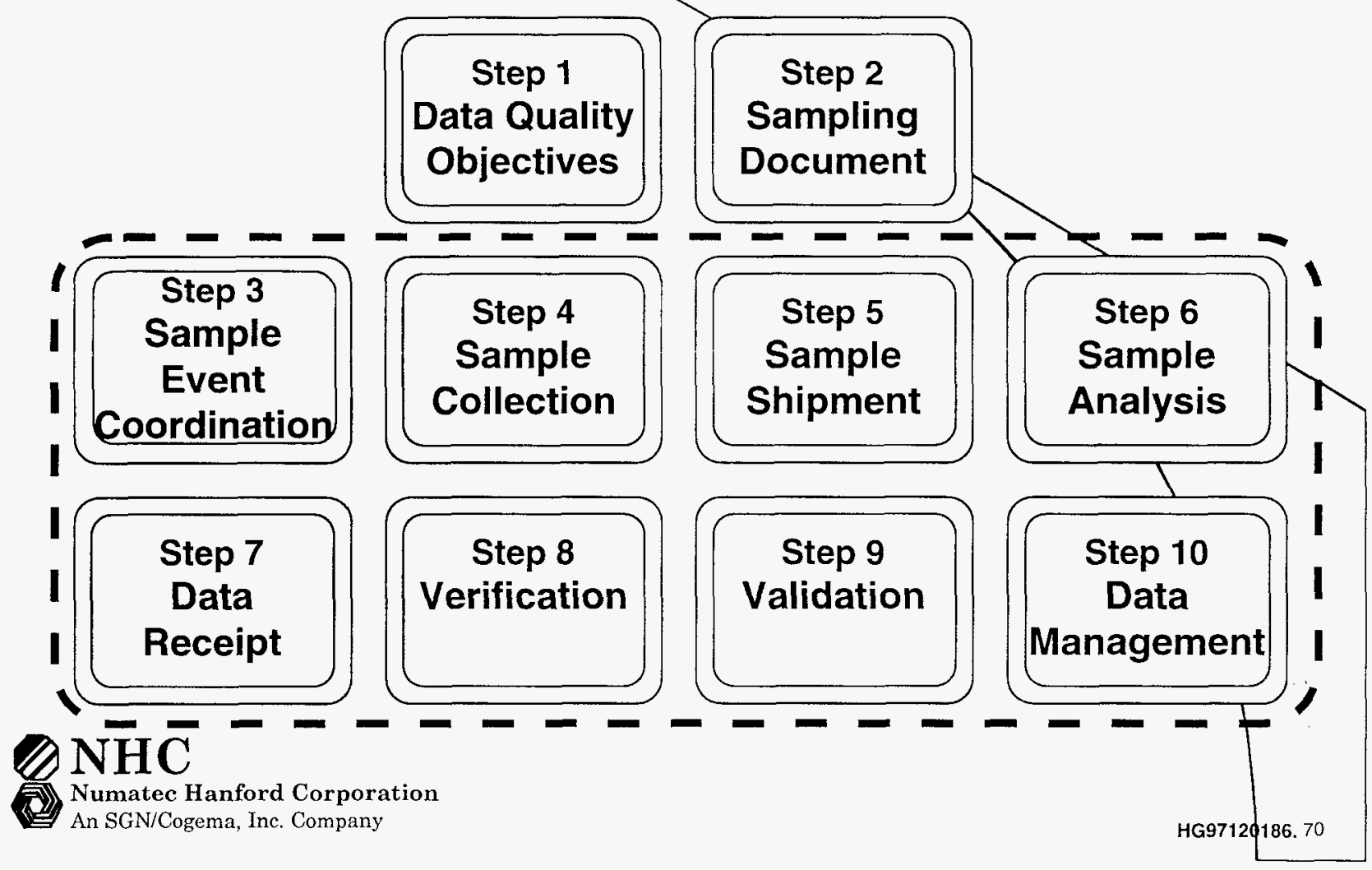




\section{Sample Analysis}

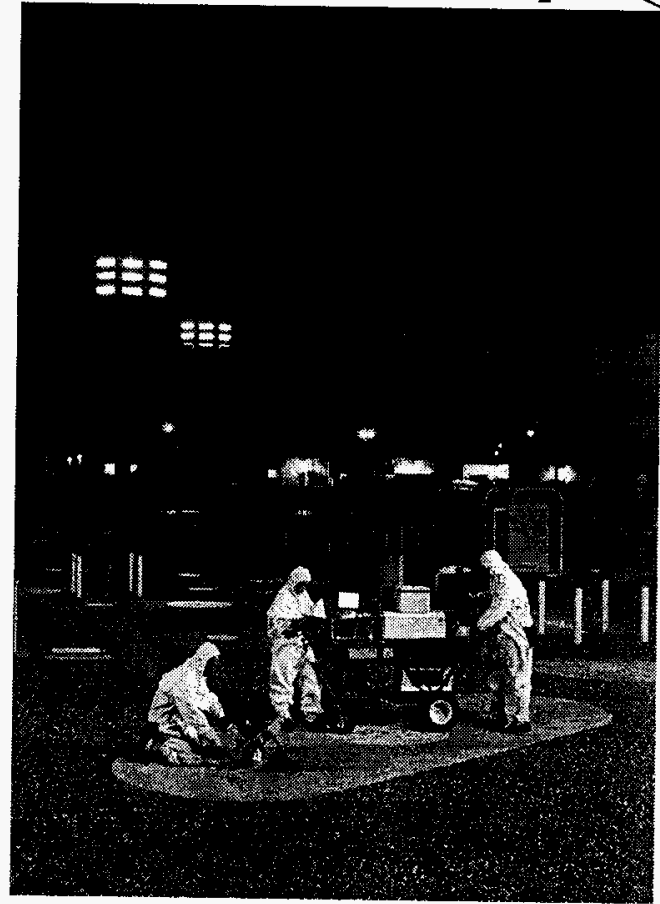

Purpose

- To provide the analyticaNools needed to meet Task Manager needs and produce quality data in a timely and cost effective manner 


\section{Sample Analysis Process}
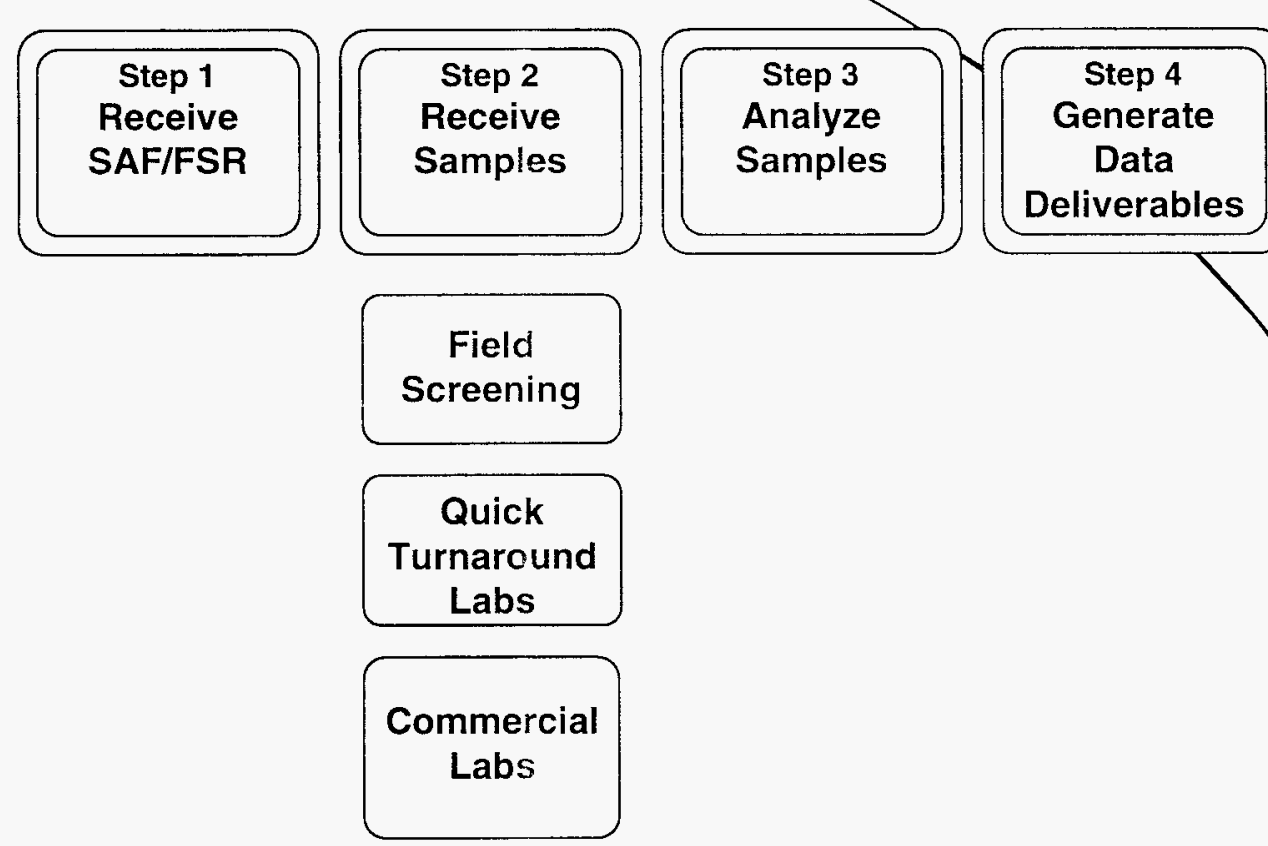

Field

Screening

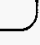




\section{Sample Analysis (continued)}

\section{Process Description (continued)}

- Receive Sampling Analysis FormXFierd Sampling Report (SAF/FSR) electropically Analyze samples and report results

- 1 and 50 day turnaround

- Provide data electronically via electronic bulletin board

- Provide paper record copy 


\section{Sample Analysis (continued)}

Process Description (continued)

- Quick Turnaround

- 48 Hour turnaround

- Confirmation analysis with commercial Iab

- Provide paper record copies 


\section{Sample Analysis}

(continued)

\section{Process Description (continued}

- Field Screening (On-Site Analysis)

- Immediate results

- One-on-one communications (in field)

- Confirmation analysis with quick turnaround

- Provide paper copies of data 


\section{Sample Analy
Process Strengths}

- Flexible strategy to provide timely and cost effective analytical services

- Each level of service is tied to more rigorous quality control requirements 


\section{Sample and Data Management Process Flow}

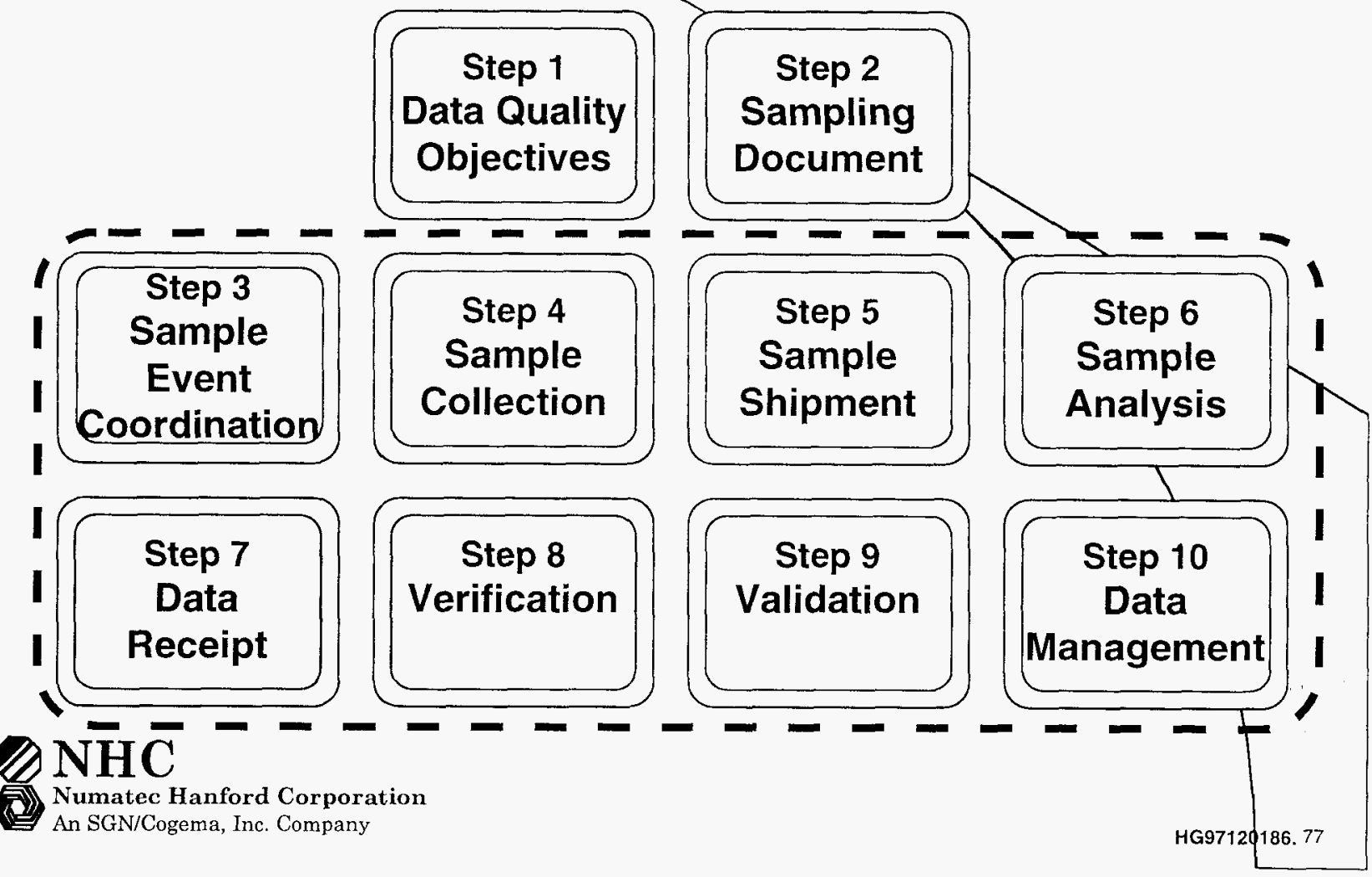




\section{Data Receipt}
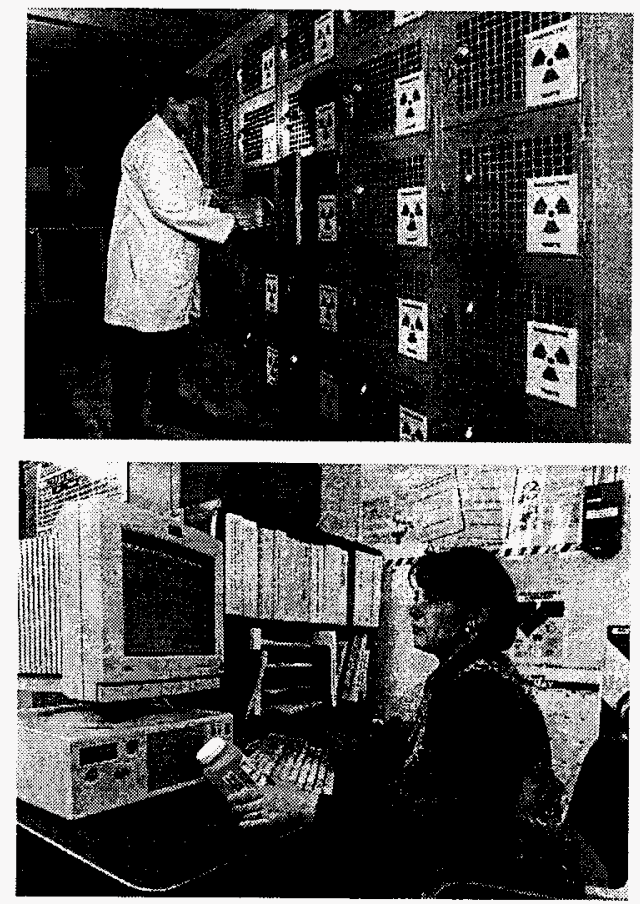

\section{Purpose}

- To establish standard methods for control, storage, access, and transmittai of data deliverables 


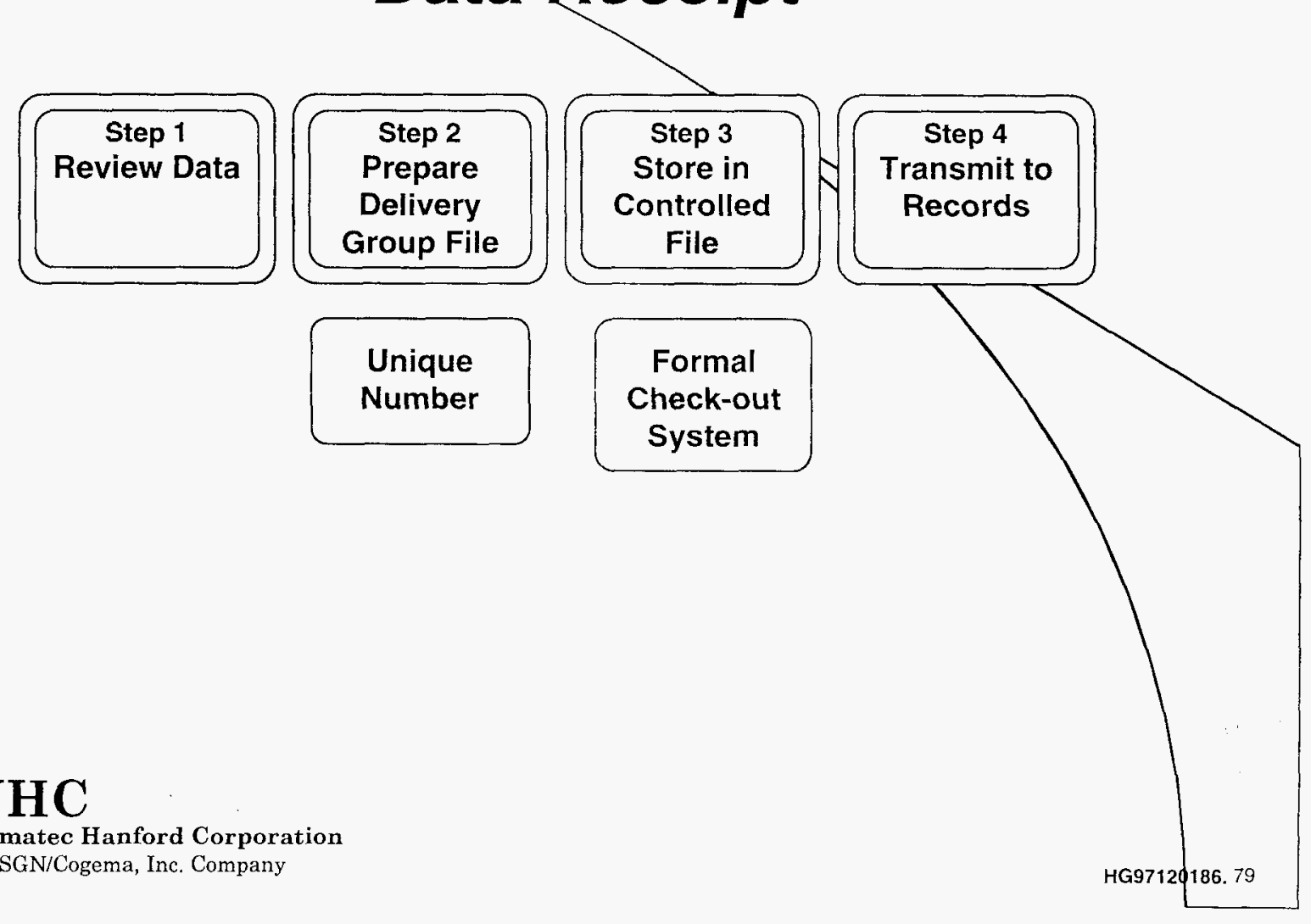

DataReceipt 


\section{Data Receipt}

\section{Process Descrip}

- Data reviewed against Chain-of-Custody and analysis request to ensure receipt of complete deliverable

- Unique number assigned to each data package during log in to create delivery group file

- Data maintained in access controlled area

- Formal Checkout system established 


\section{Data Receipt (continued)}

\section{- Process Description (co}

- Documents generated through verification and validation processes in delivery group file

- Files transmitted to Records Management after data assessment 


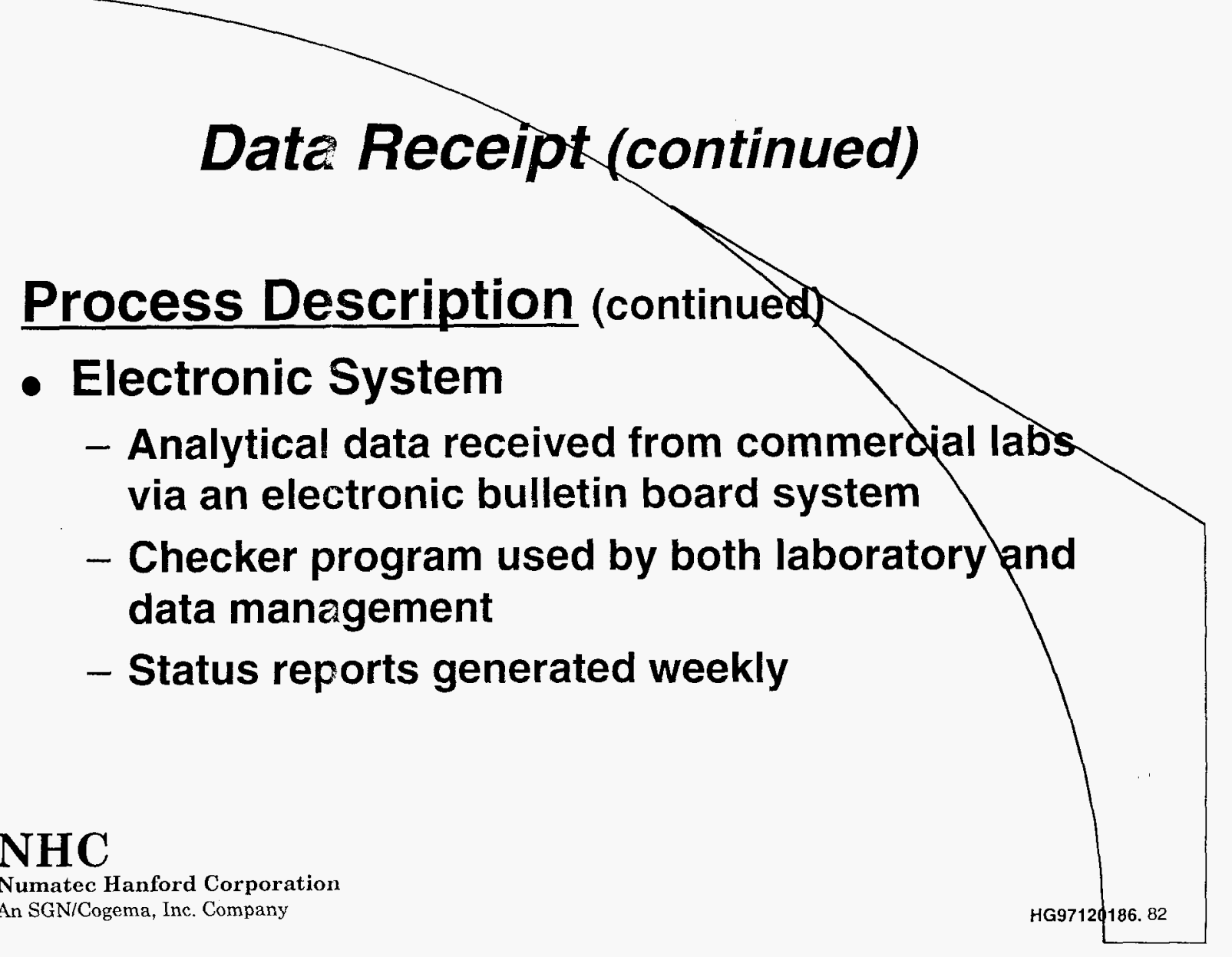




\section{Process Strengths}

- Controlled receipt, storage, and access of hard copy deliverables

- System in place for transmittal and format checks of electronic deliverables

\section{Process Weaknesses}

- Some analytical resources in process
implementing electronic deliverables 


\section{Sample and Data Management}

Flow Rrocess

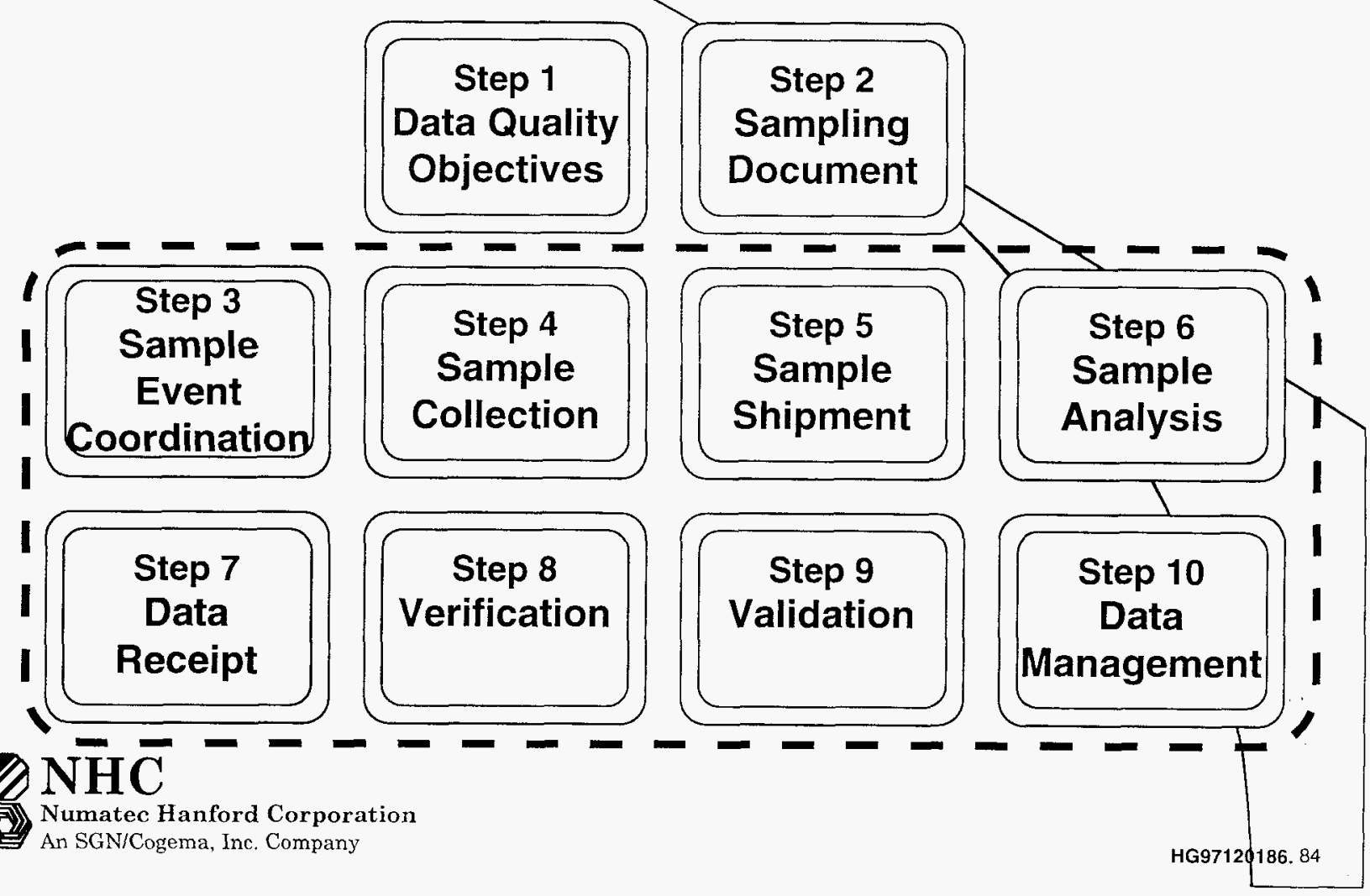




\section{Data Verification/Validation}

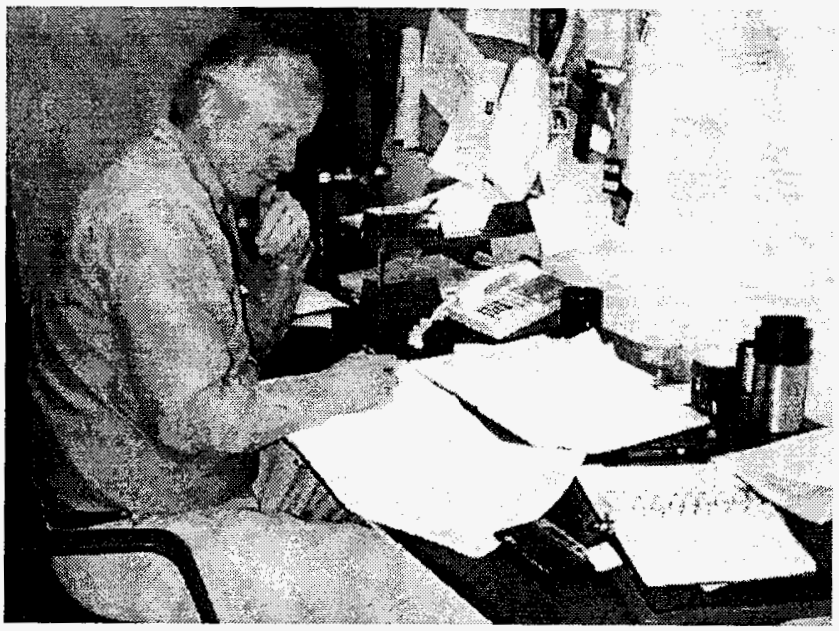

Purpose

- To verify completeness of data received from analytical resources and establish data of known quality that can be evaluated against intended use criteria

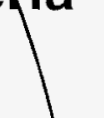

NHC

Numatec Hanford Corporation

An SGN/Cogema, Inc. Company 


\section{Data Verification/Validation Process}
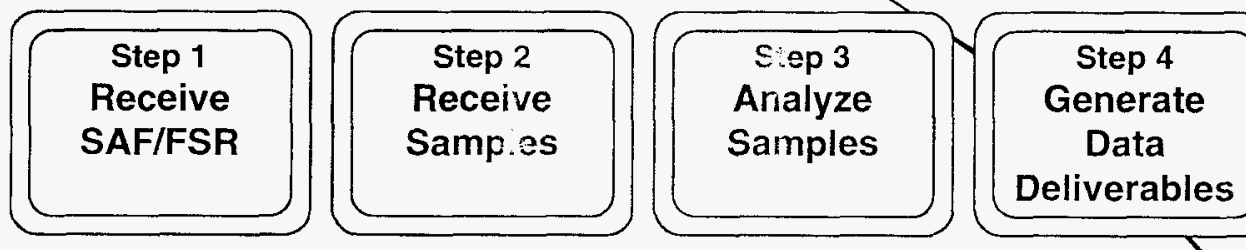

Administrative

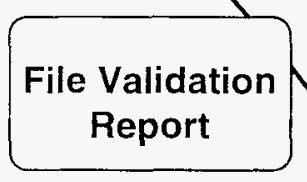

Technical

$\mathrm{NHC}$

Numatec Hanford Corporation

An SGN/Cogema, Inc. Company 


\section{Data Verification/Validation}

(continued)

\section{Process Description}

- Administrative verification

- Page by page review of package for pagination and copy quality

- Deficiencies communicated to analytical resources for closure 


\section{Data Verification/Validation}

(continued)

\section{Process Description (continued)}

- Technical Verification

- Review of ana ytical deliverable for technical completeness

- Presence/Absence of deliverable elements documented on checklists

- Deficiencies communicated to analytical resources for closure

( 2 day response time) 


\section{Data Verification/Validation}

(continured)

\section{Process Description (continued)}

- Validation

- Functional guidelines approach

- Graded option available

- Process done on paper (3-4 week turnaround)

- Validation documents managed as Quality Assurance records

- Services contracted to manage workload fluctuations 


\section{Sample and Data Management Flow Rrocess}

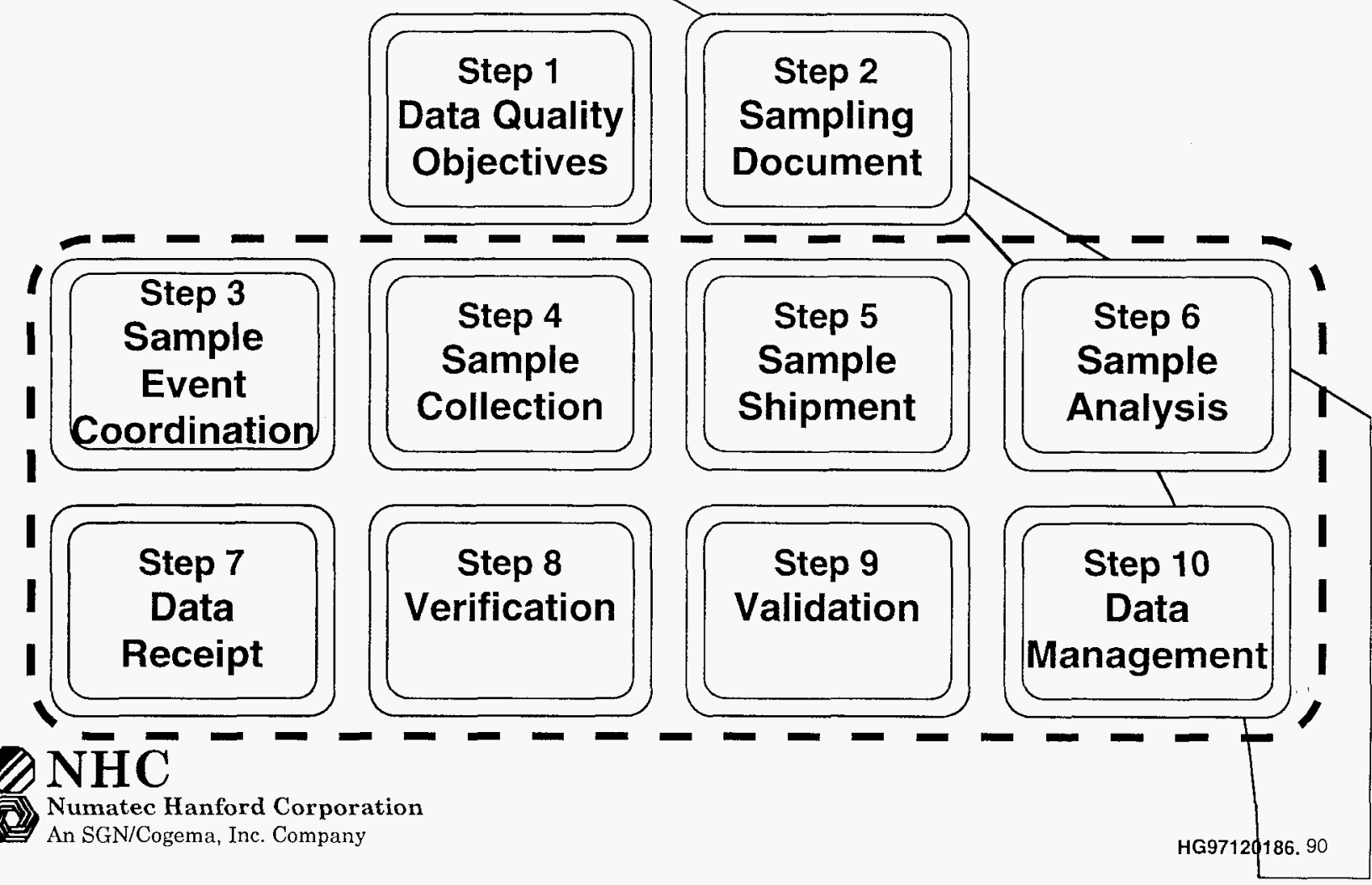




\section{Data Management}

\section{Purpose}

- To provide controlled access to legally defensible environmental data to meet the requirement that managers, scientists, and regulators are able to access the data in a timely manner to perform their work activities 


\section{Data Management Process}
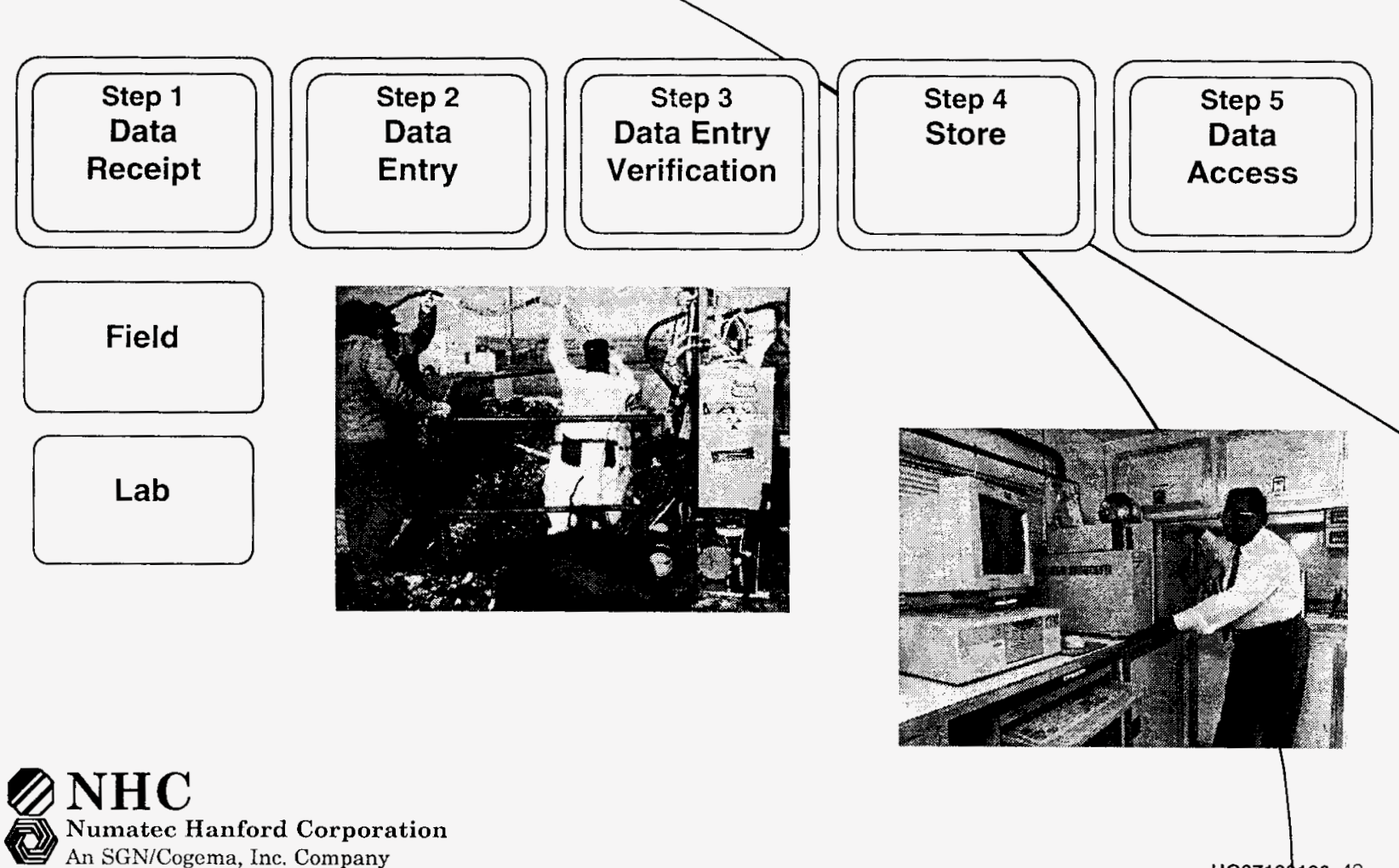

HG97120186. 49 


\section{Data Management (continued)}

\section{Process Description}

- Data Receipt

- Electronic

- Analytical data received from laboratories

- Hard Copy

- Sampling event data

- Quick turnaround lab data

- Field Screening data 


\section{Data Management (continued)}

\section{Process Description (continuted)}

- Data Entry

- Electronic data is loaded into the database using tested loader code

- Hard copy data is loaded manually and verified for accuracy with a one-over-one peer review process 


\section{Data Management (continued)}

Process Description (continued)

- Storage

- Analytical data/sampling event information

- Waste site information

- Geographic information 


\section{Data Management (continued)}

\section{Process Description (continued)}

- Data Access

- Standard Reports (Analytical data/sampling event information)

- Direct queries to database

- Windows based 


\section{Data Management (continued) \\ Process Strengths}

- All analytical data from labs is being received electronically into the database

- Analytical data is available within 24 hours of receipt

- Database is under configuration management

- Database provides unique sample numbers prior to sampling 


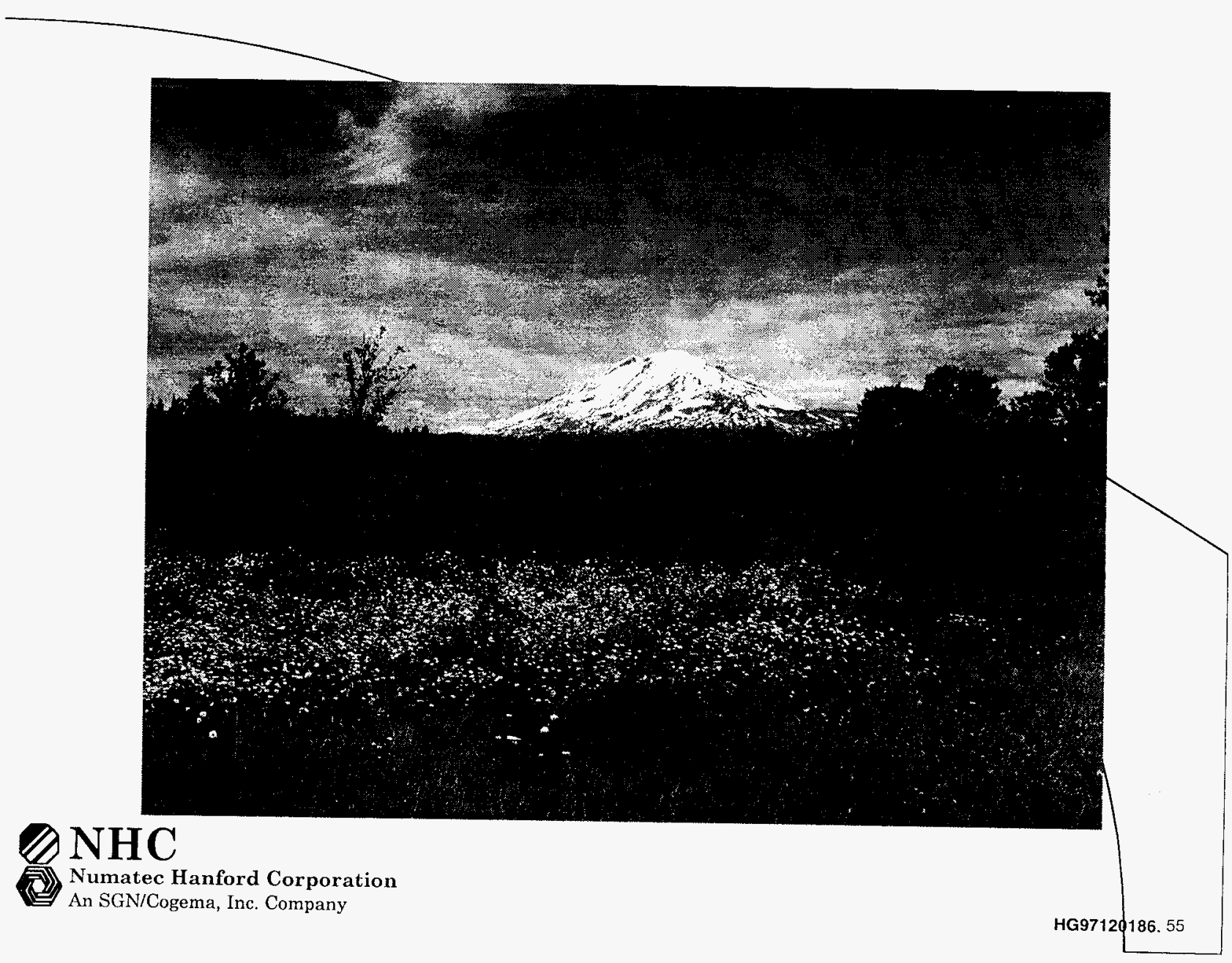




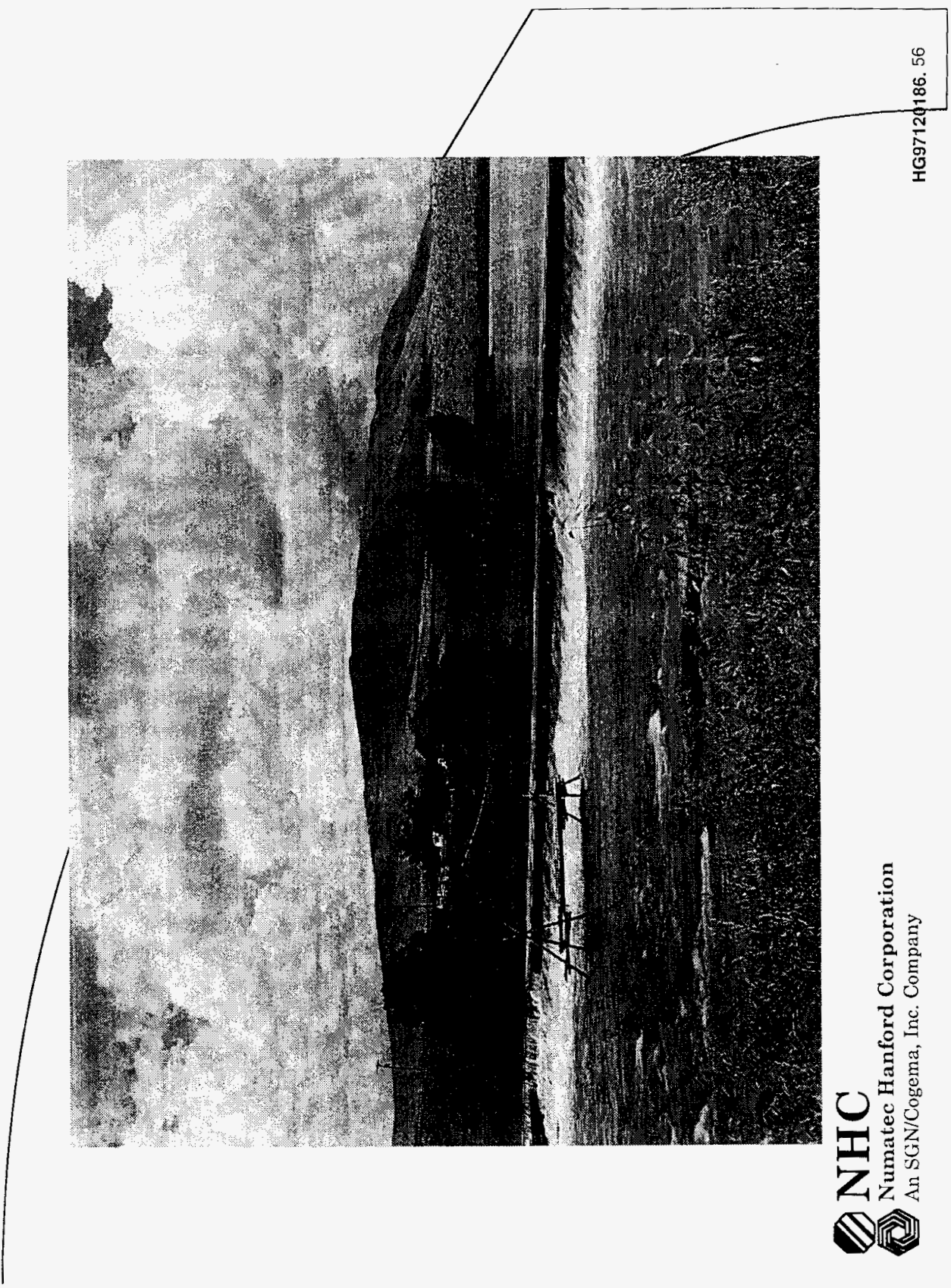




\section{Closing Rema
Questions?}




\section{Section}

\section{Cradle to Grave Sample Data}

Management

- Sample and Information Retrieval System

-Relational Laboratory Information Management System 


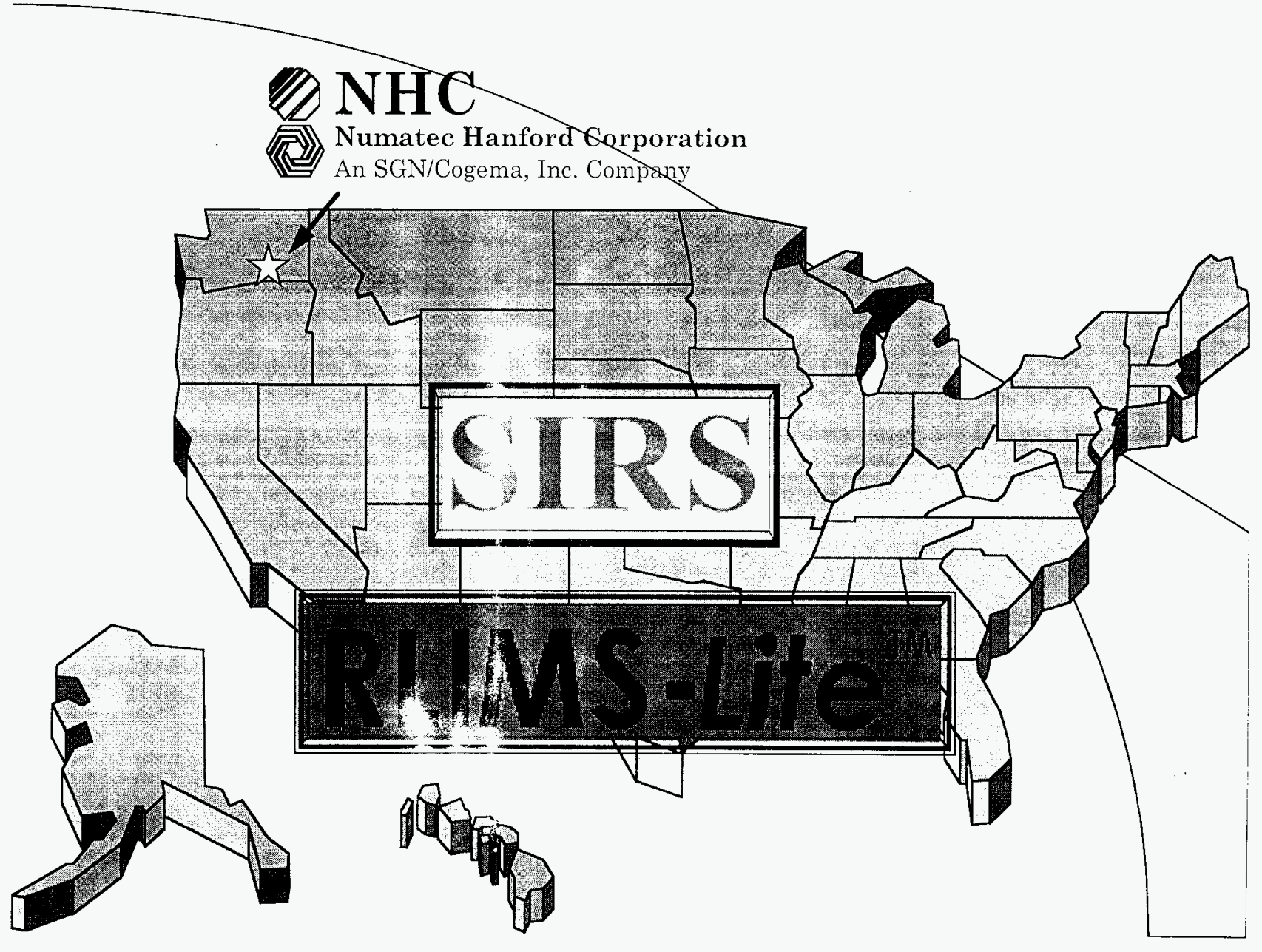




\section{Based Upon Microsoft Product Line}

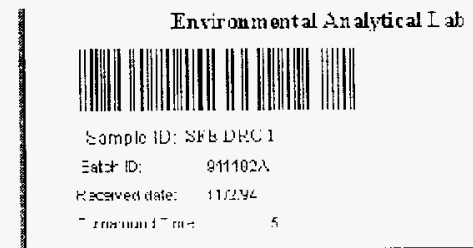

FAI SMNIPLE RTSLLTS - BATCH 9\$1102A

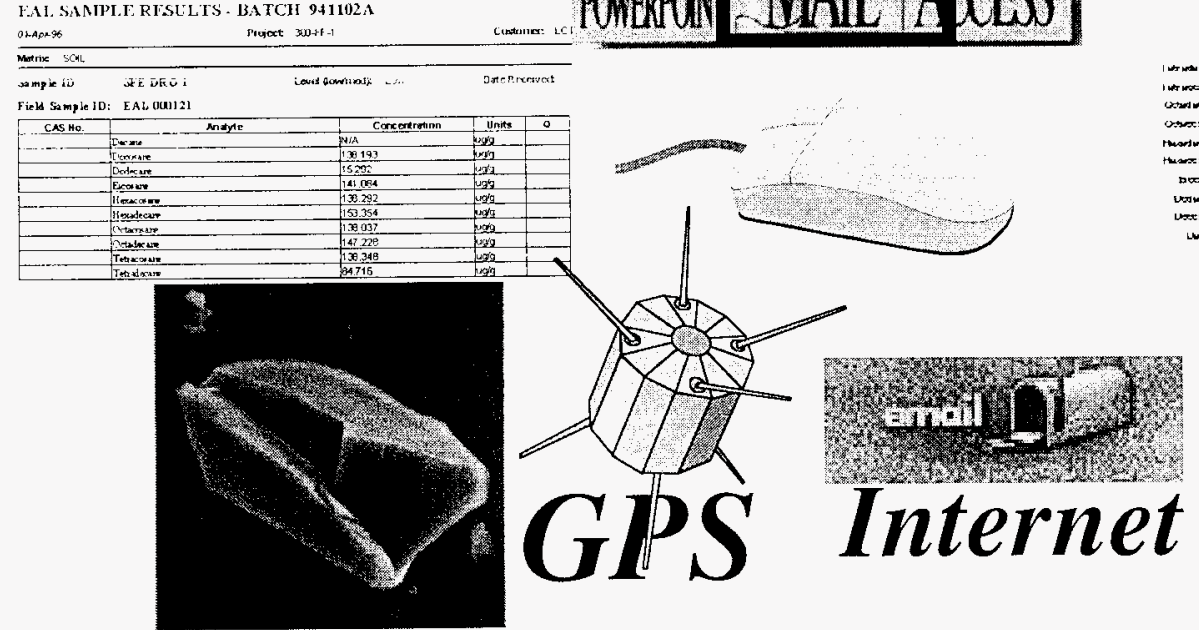

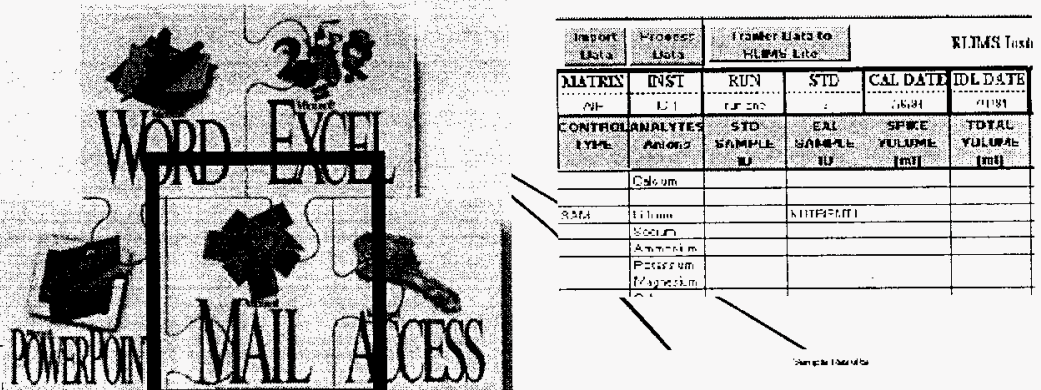
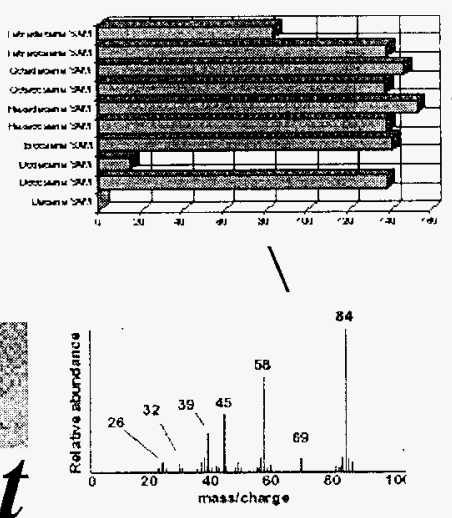


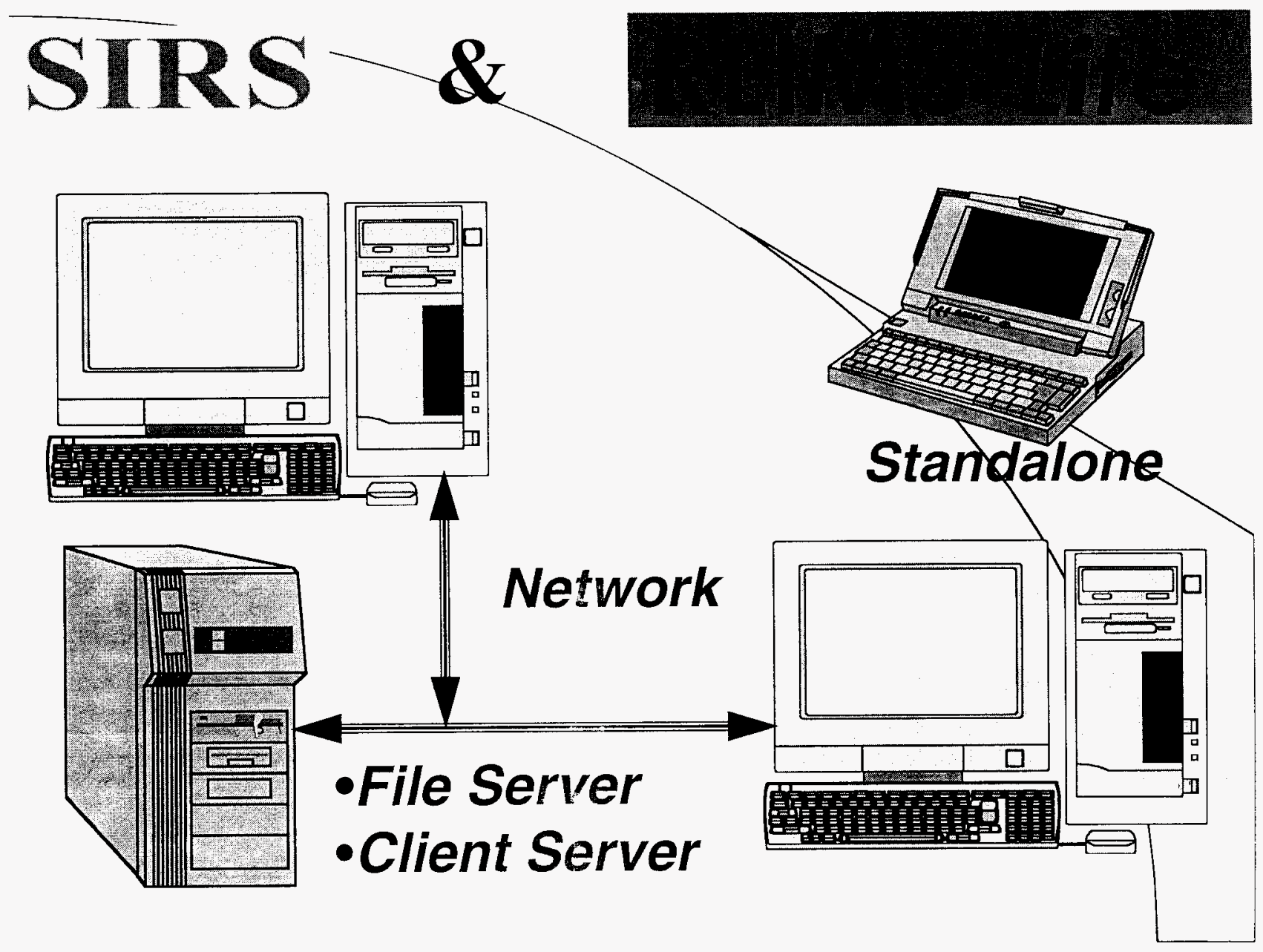




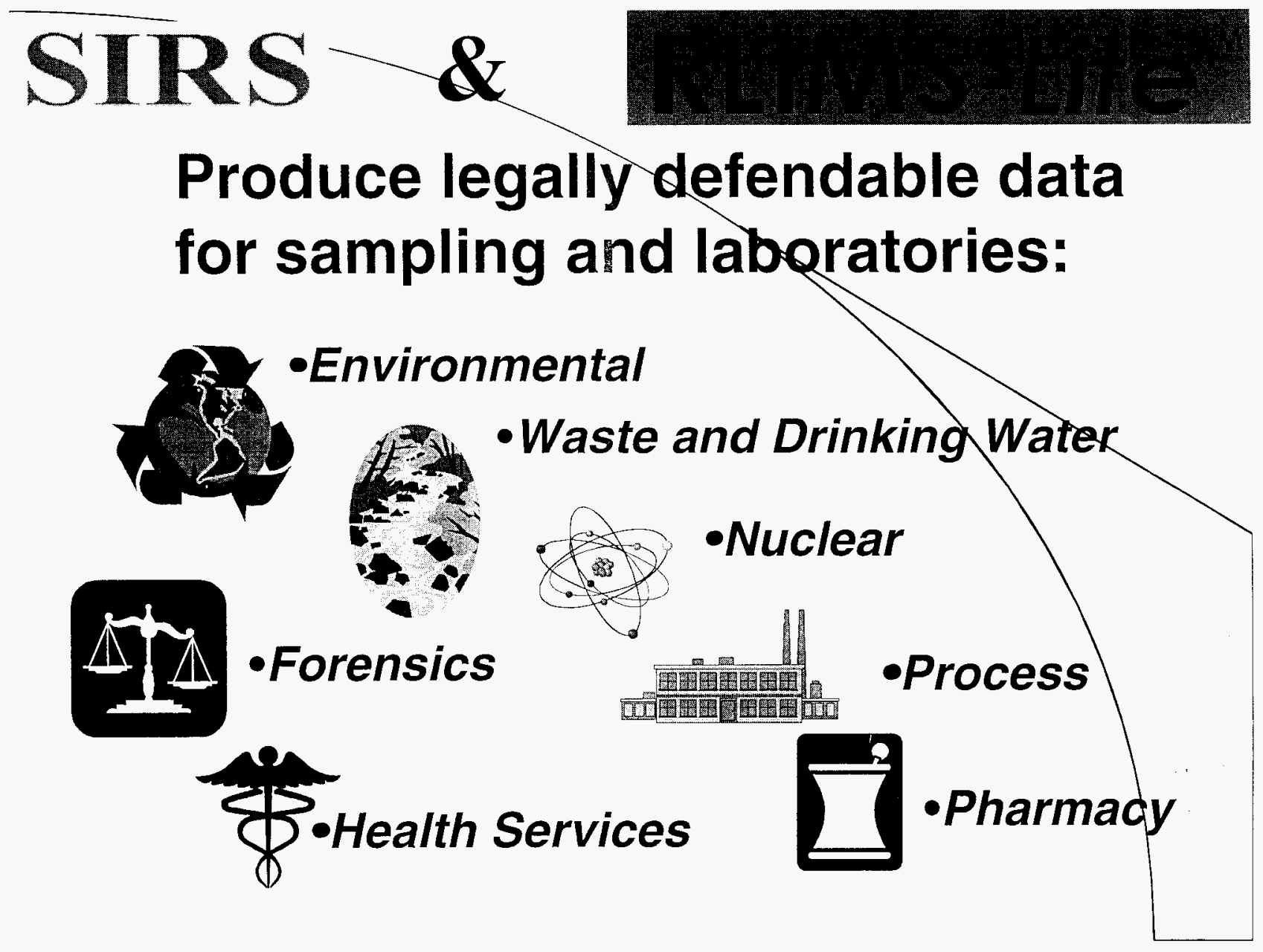




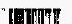

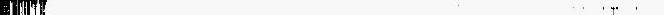




\section{SIRS}

\section{An Automated} Sampling and Information Retrieval System
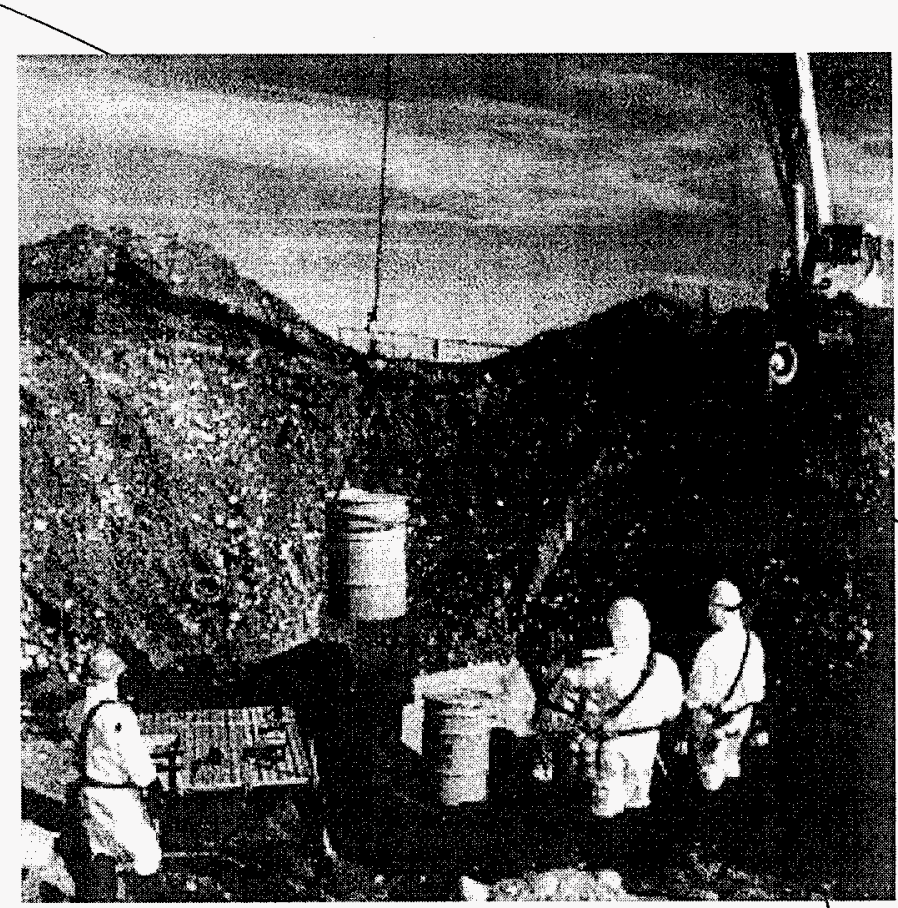


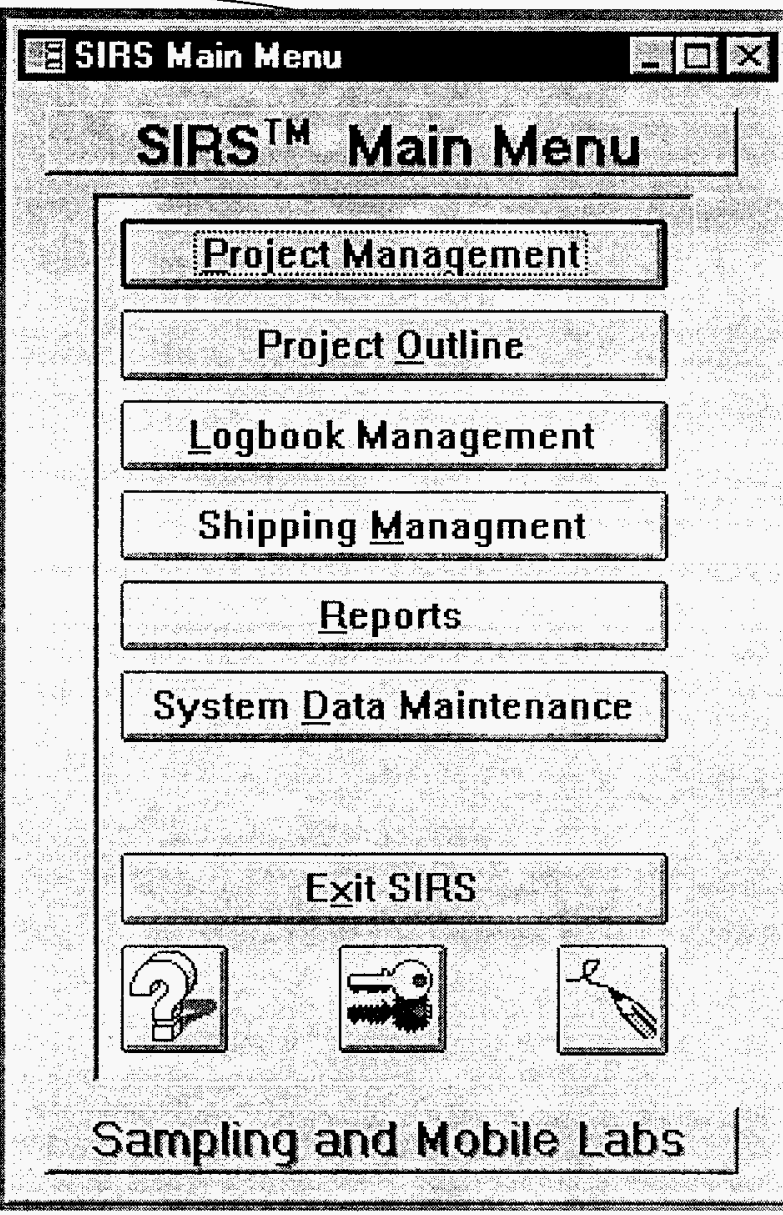

\section{Sampling Information and Retrieval System}

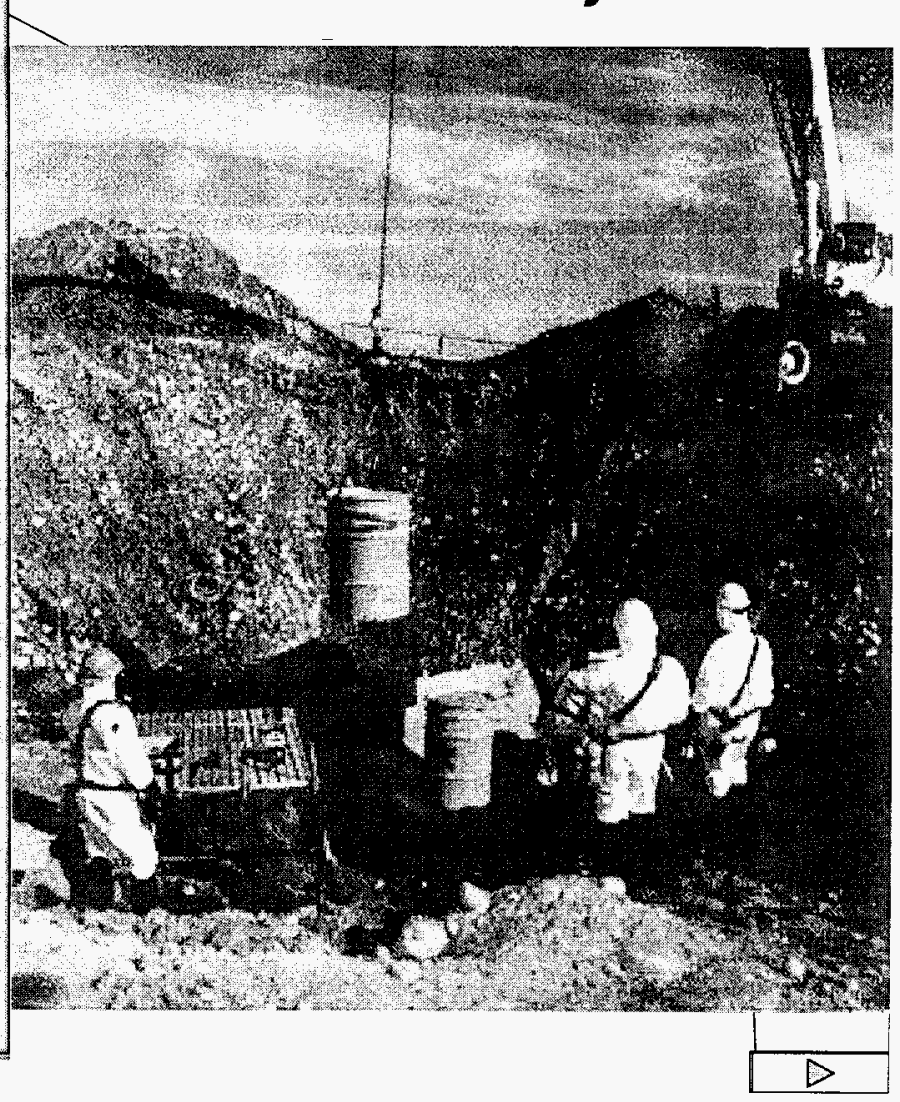




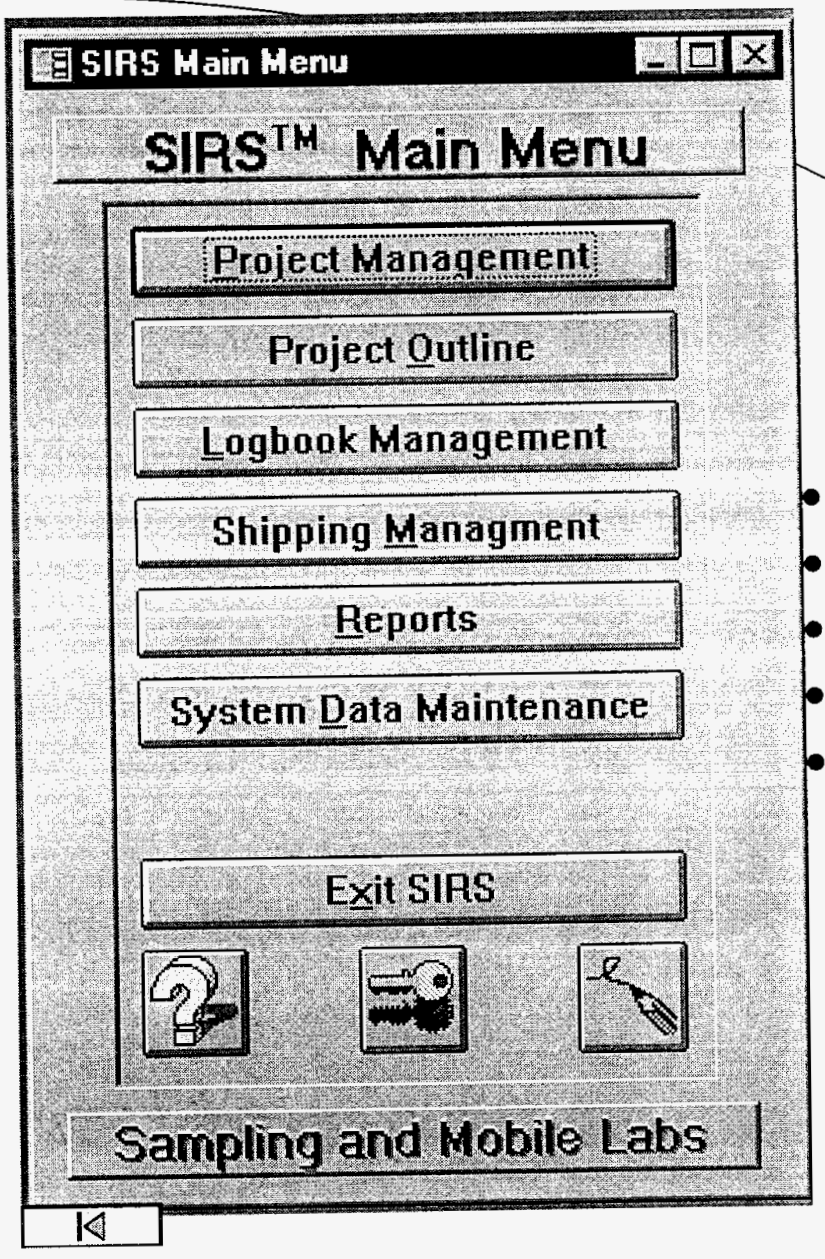

\section{Sampling Information and Retrieval System}

- Establishes project plan

- Plans sampling activity - Assists in work preparation - Logbook data entry - Produces documentation

- Labels

- Chain of Custody

-Shipping documents

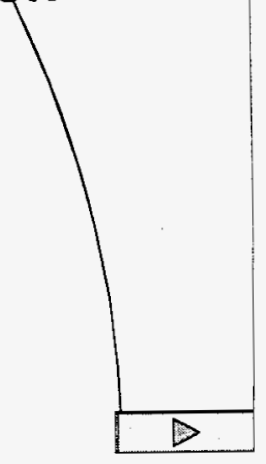




\section{Sample Planning}

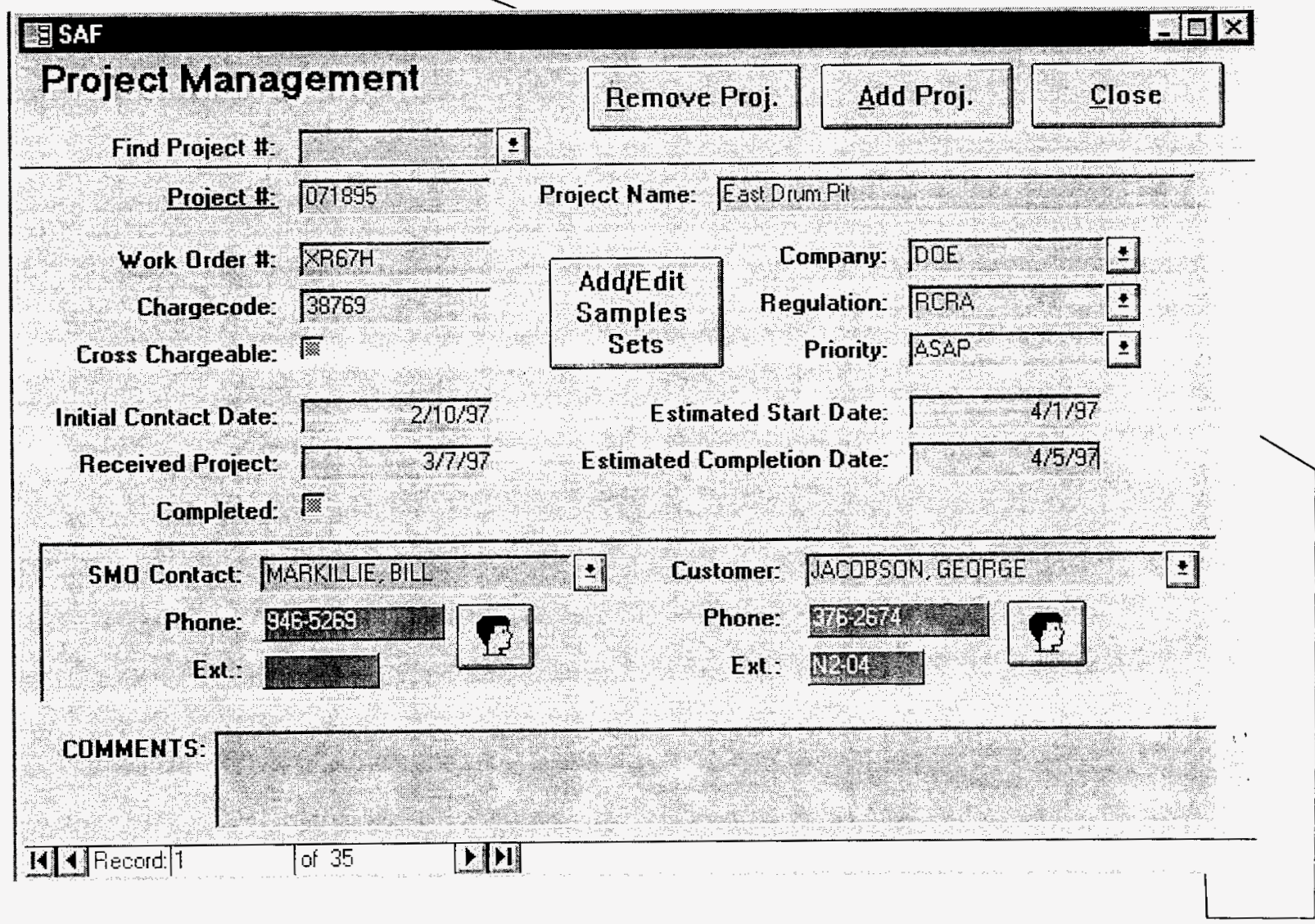




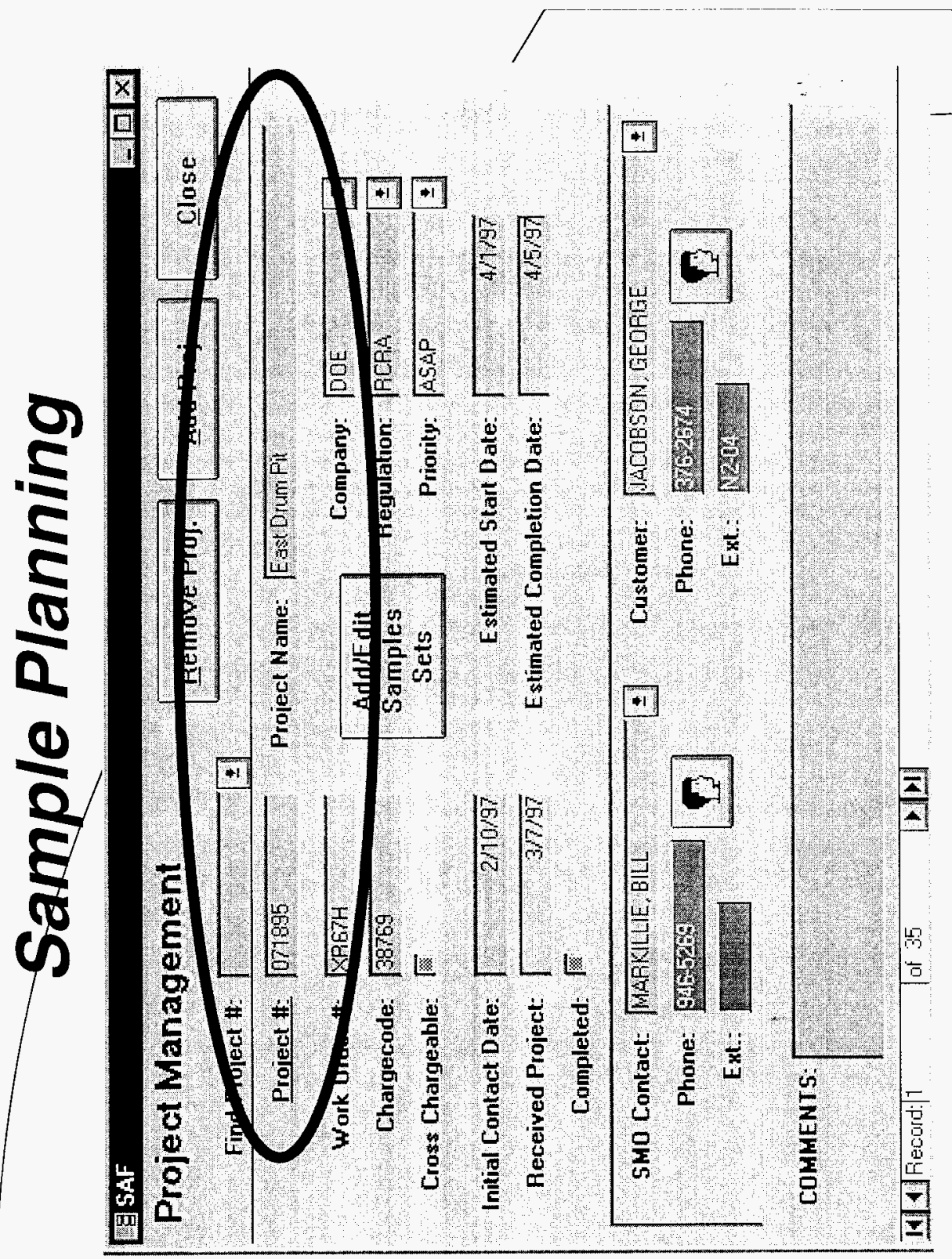




\section{Sample Planning}

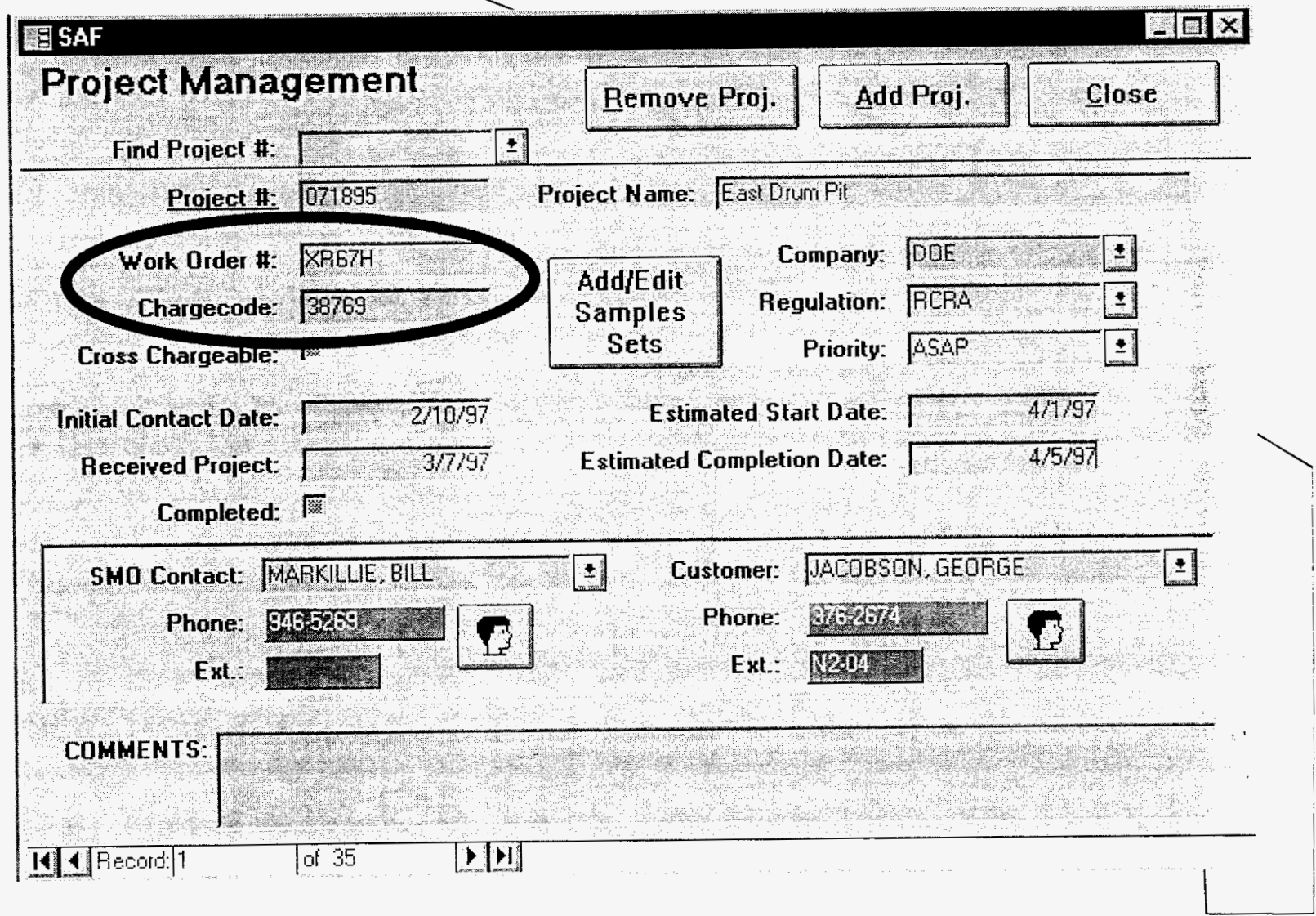




\section{Sample Planning}

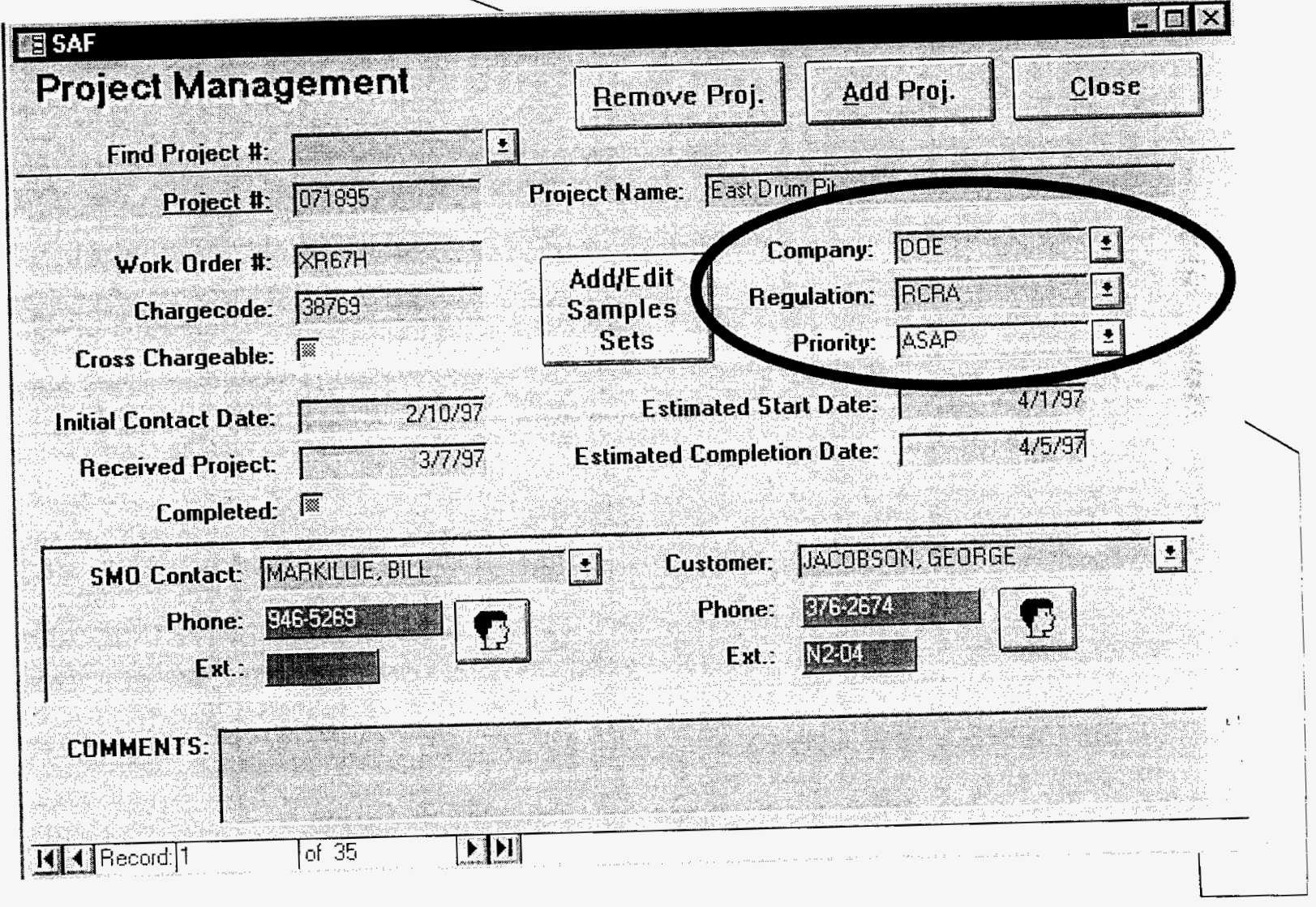




\section{Sample Planning}

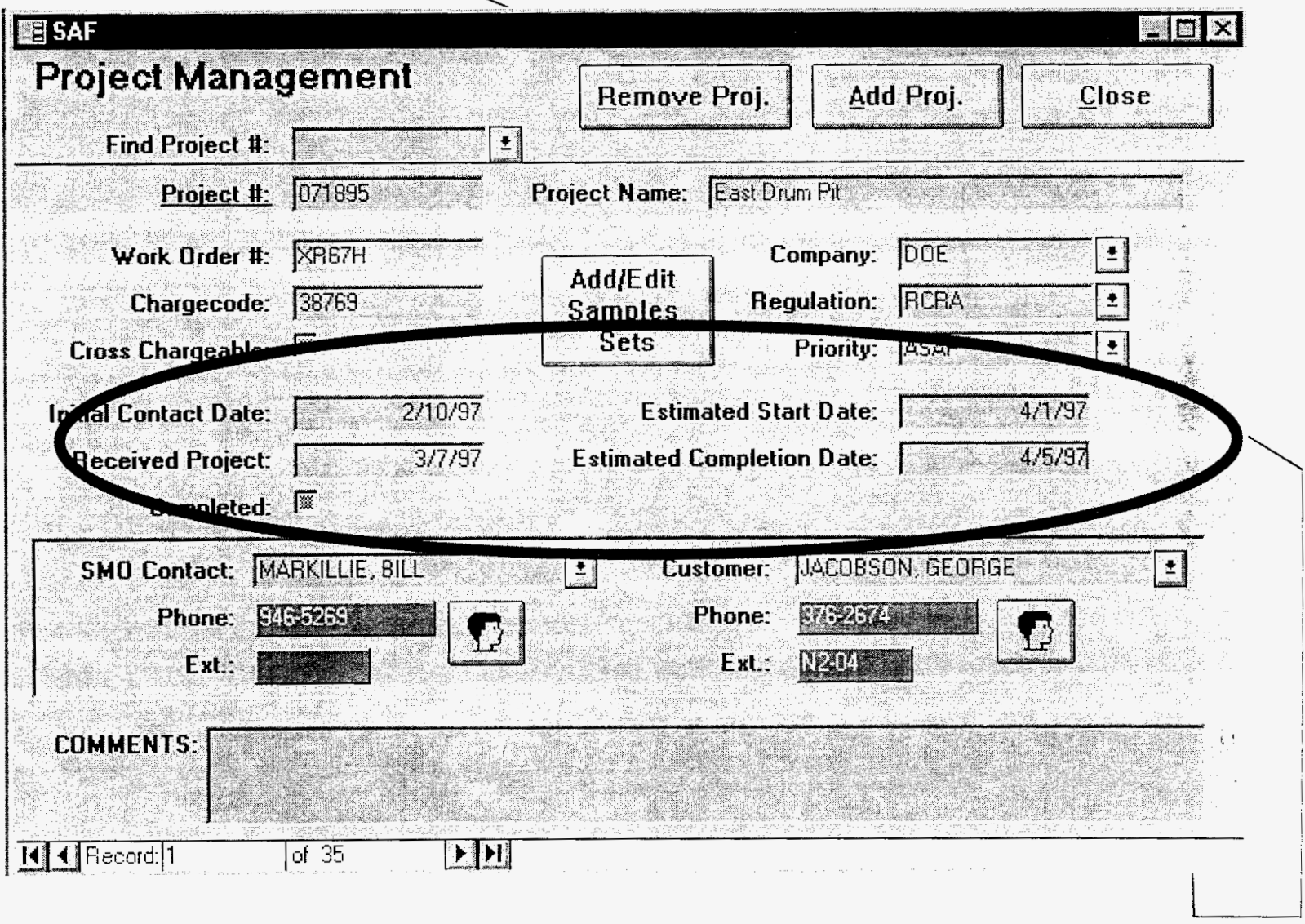




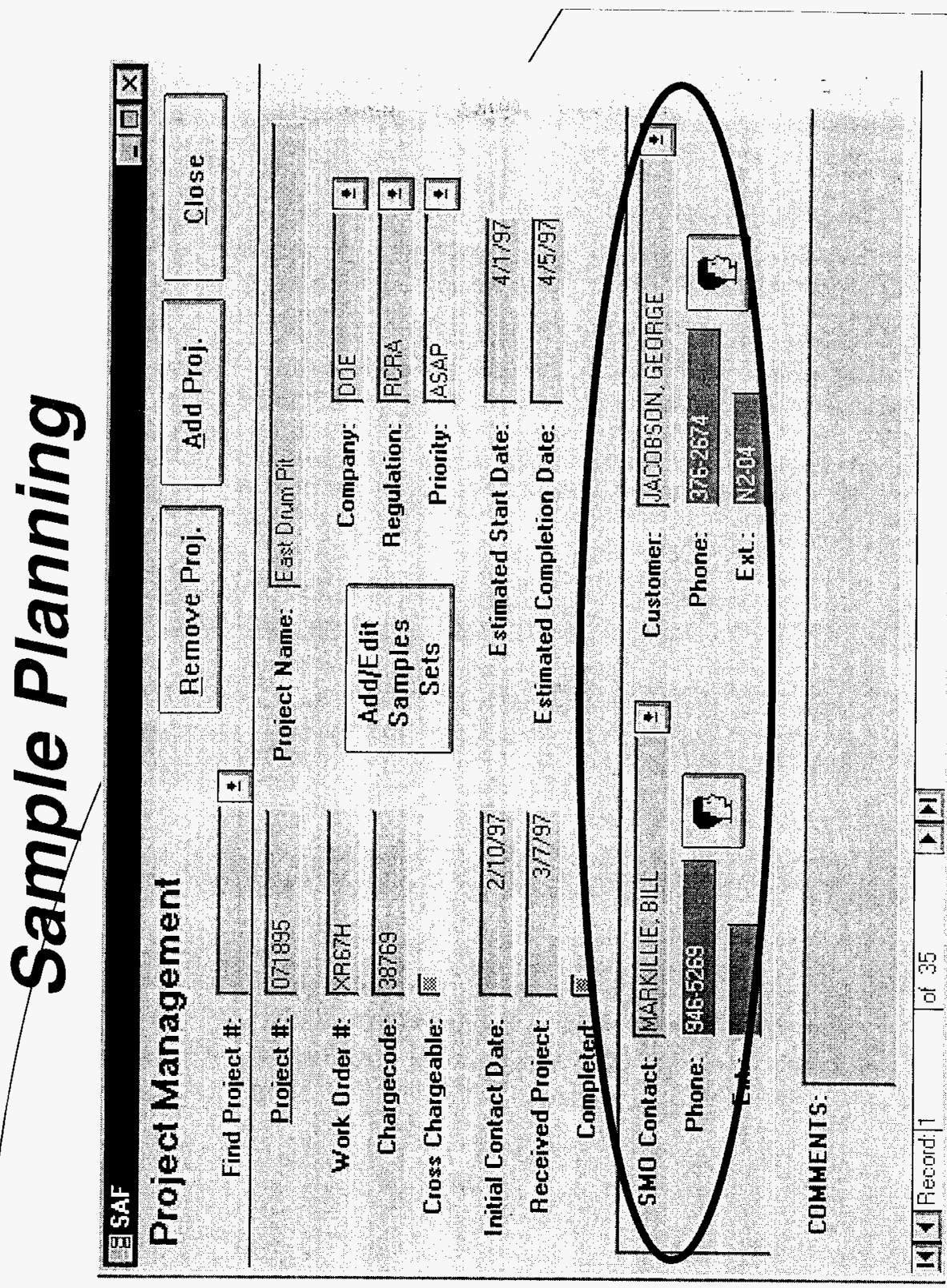




\section{Sample Planning}

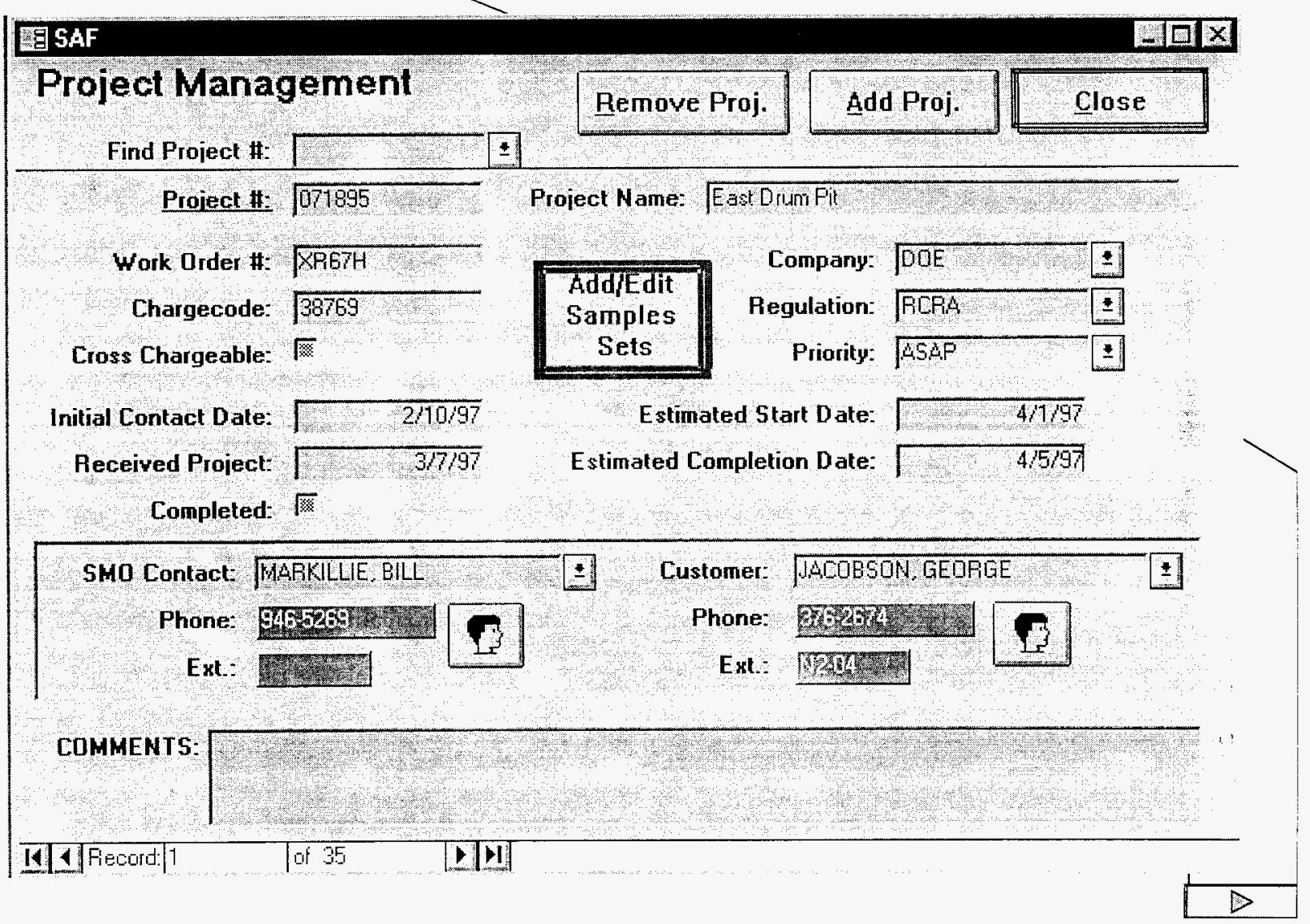




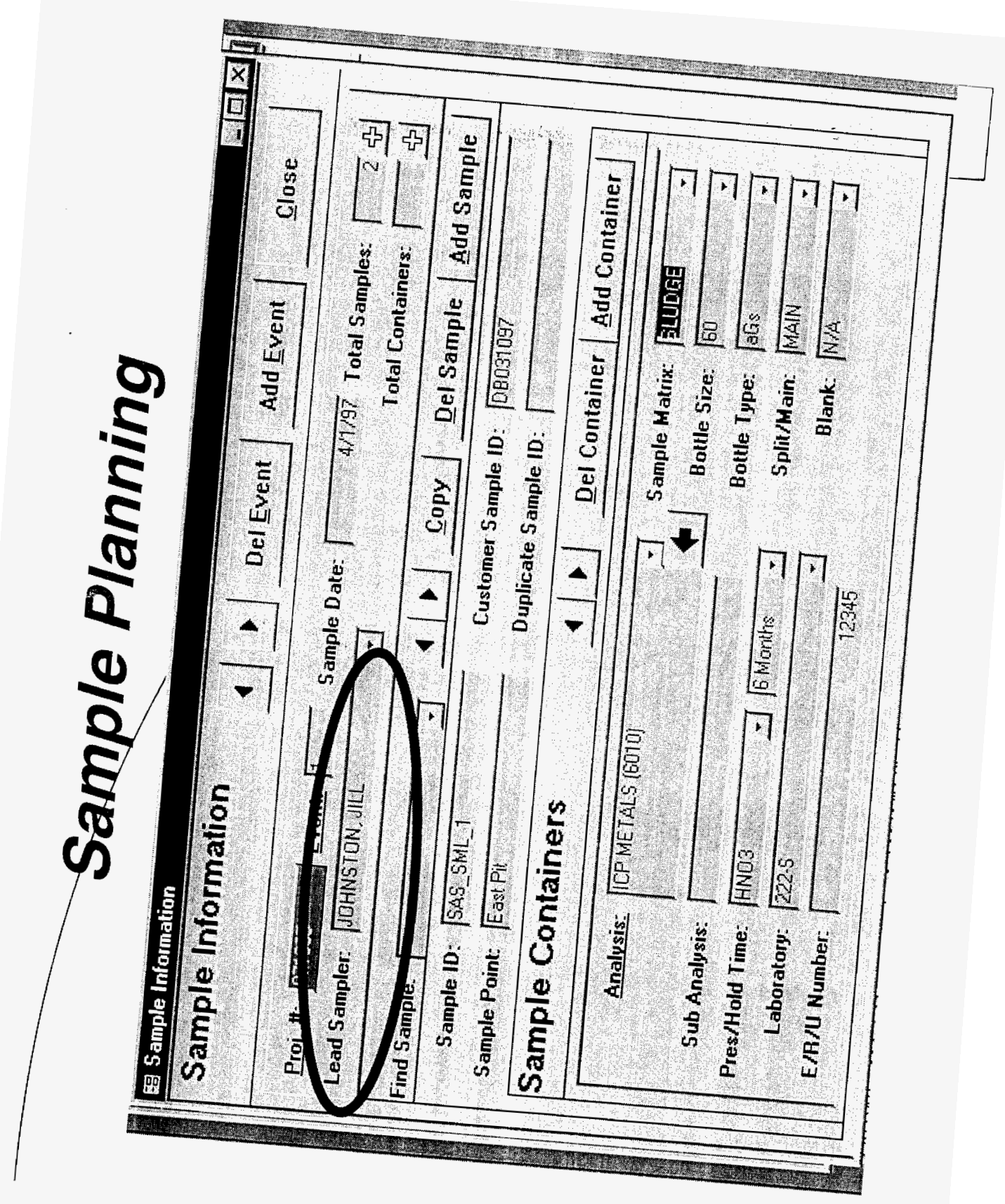




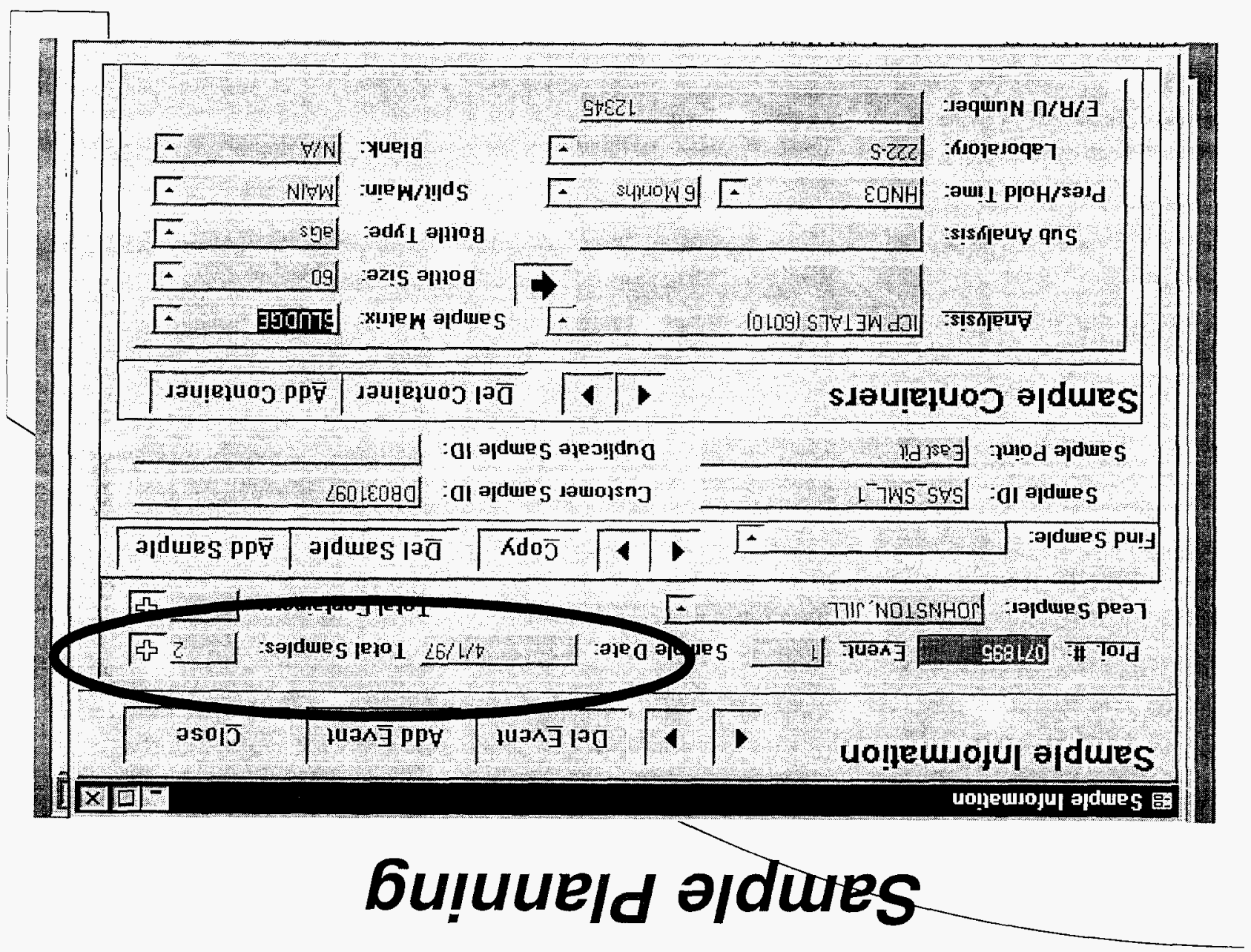




\section{Sample Planning}

国 Sample Information

Sample Information

$$
1 \text {-1 Del Event } \text { Add Event } \text { Close }
$$

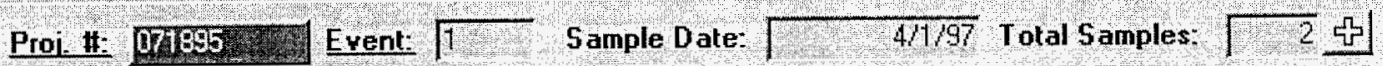

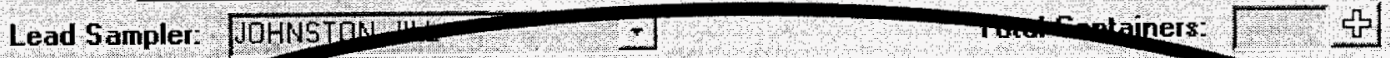

\begin{tabular}{|l|l|l|l|l|l|}
\hline Find S unple: & Copy & Del Sample & Add Samplo \\
\hline
\end{tabular}

Sample ID: SAS SML 1

Customer Sample ID. DBO31097

Sample Point East Pit

Duplicate Sample ID:

Sample Containers

\section{$\uparrow \downarrow$ Del Container Add Container}

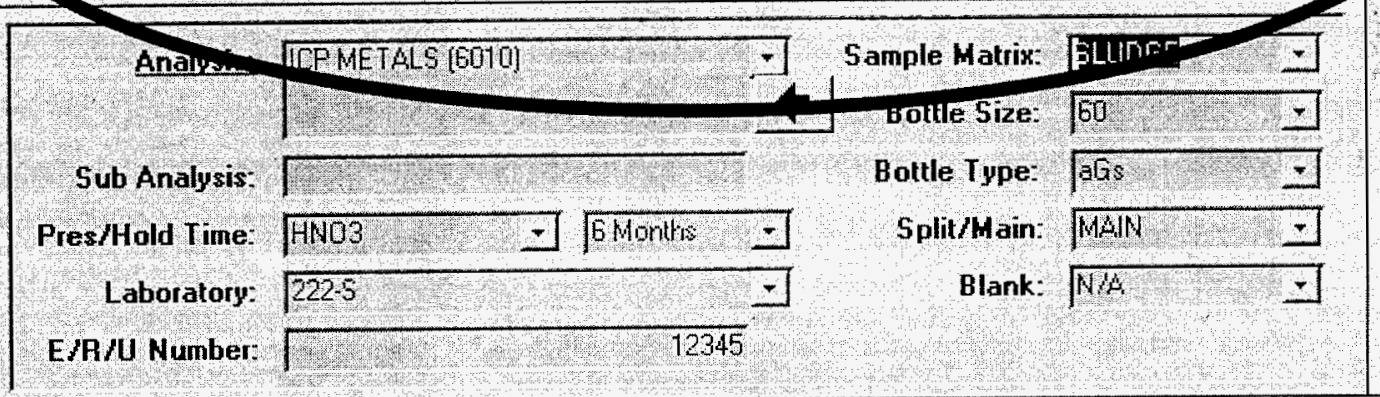




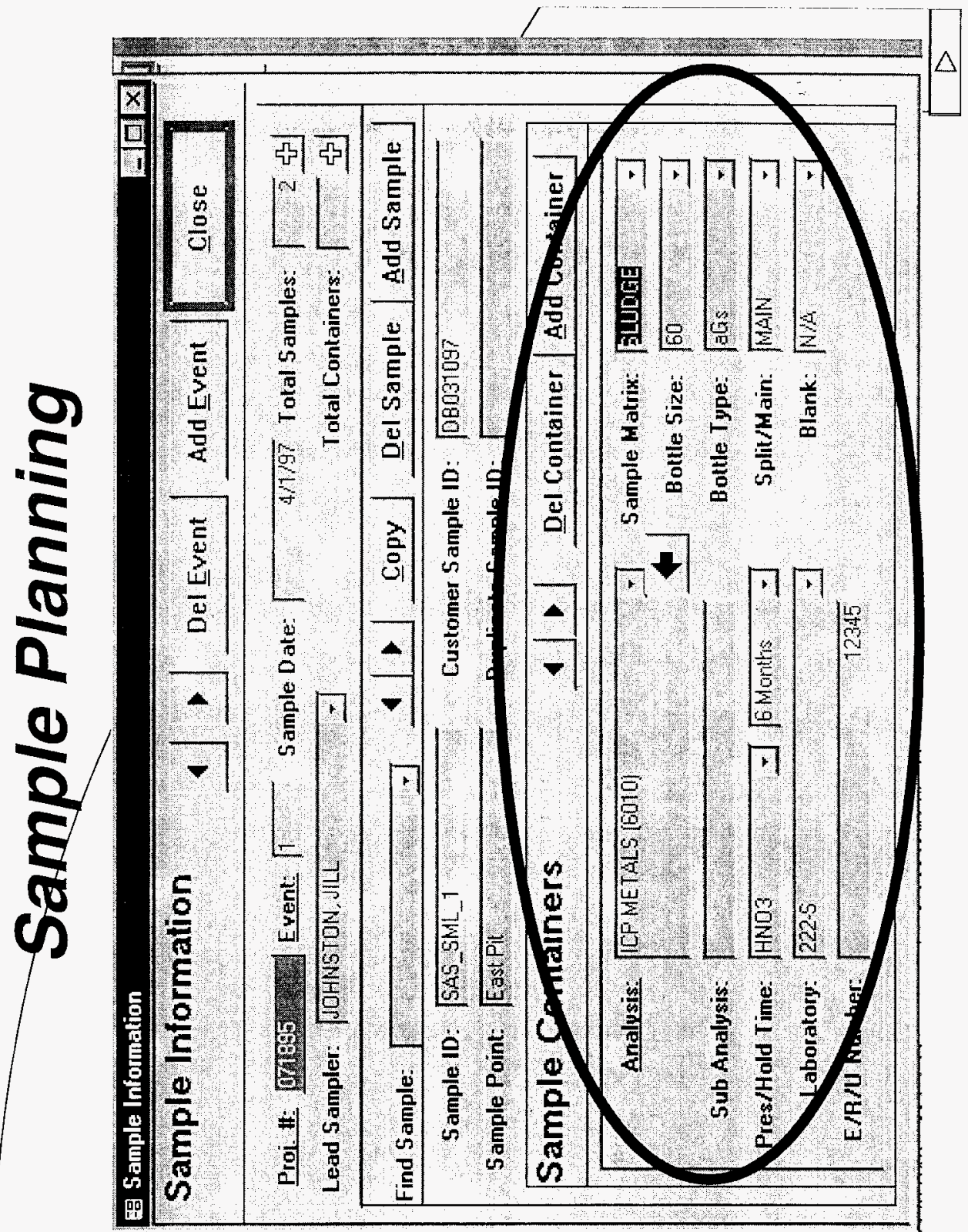




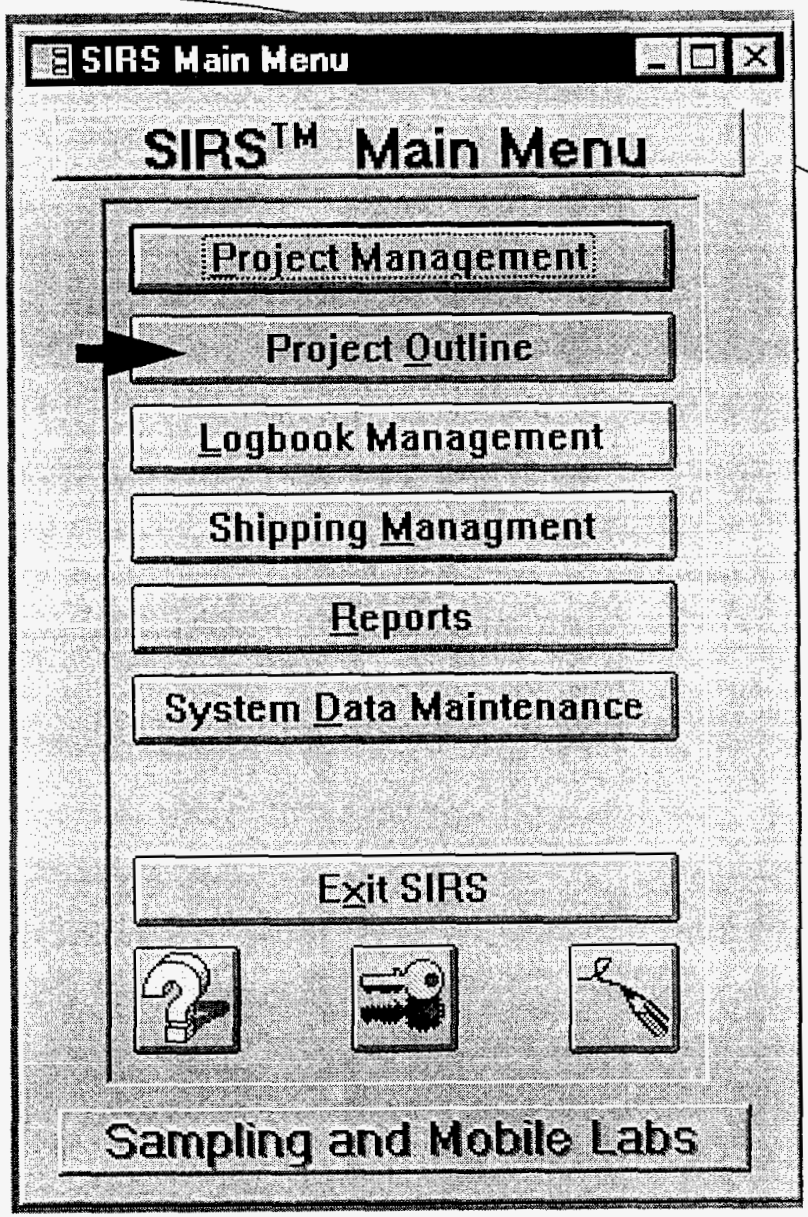

\section{Sampling Information and Retrieval System}

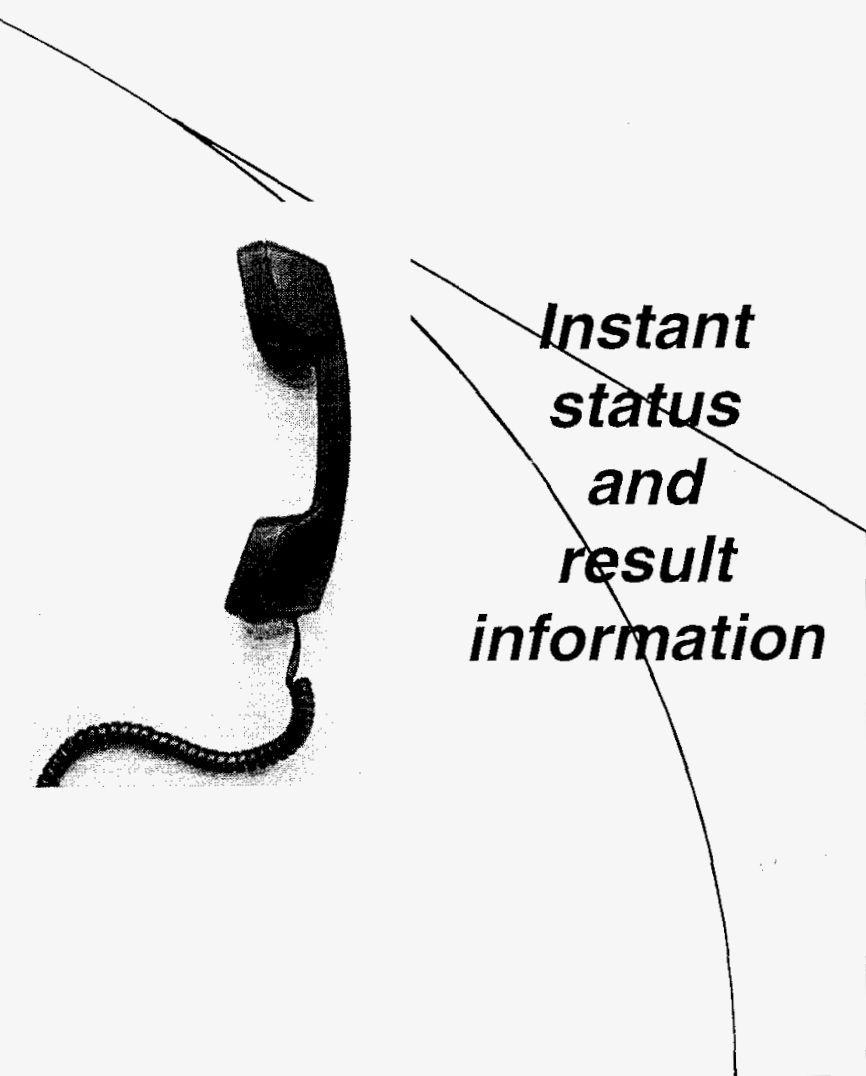




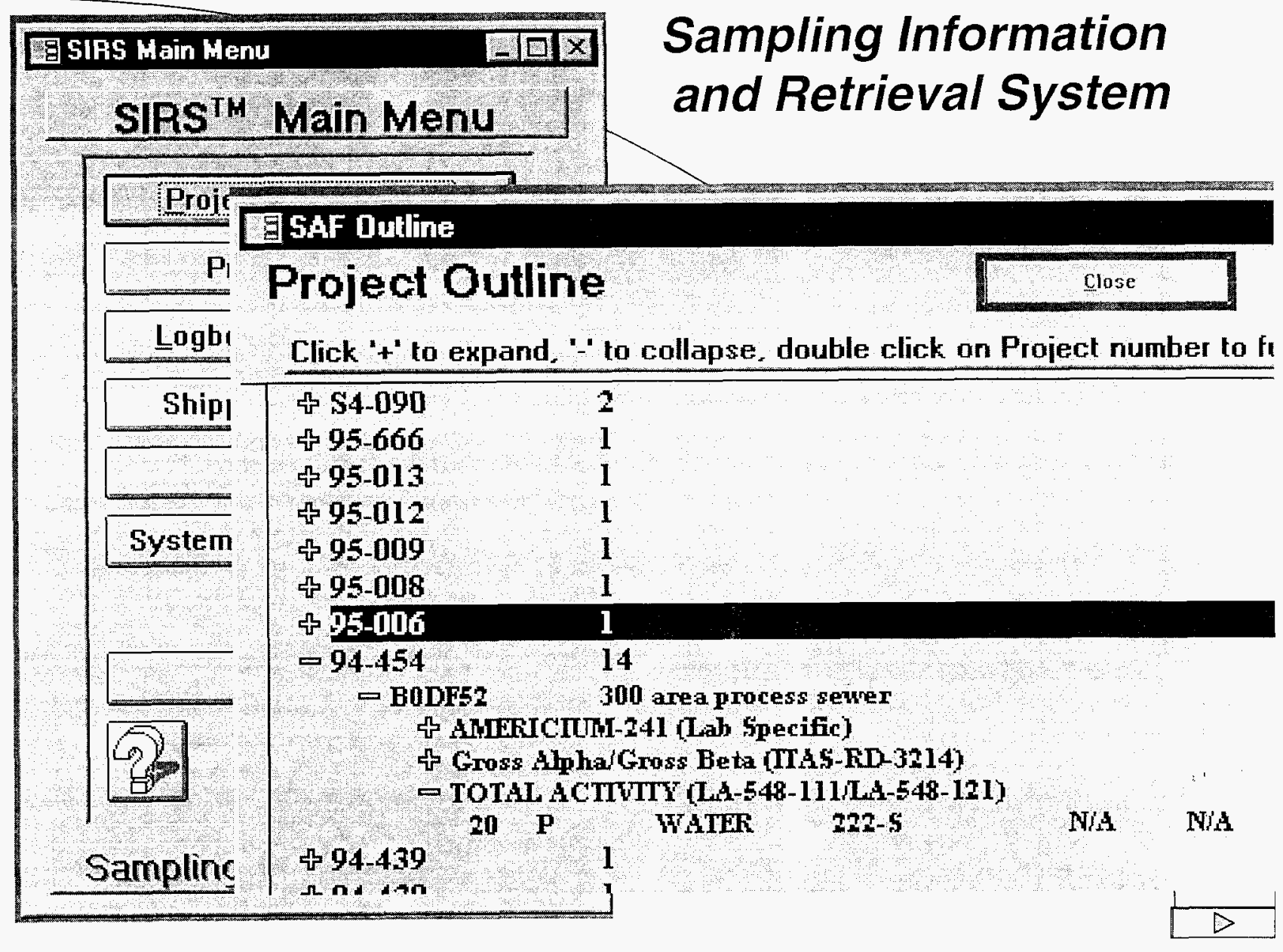









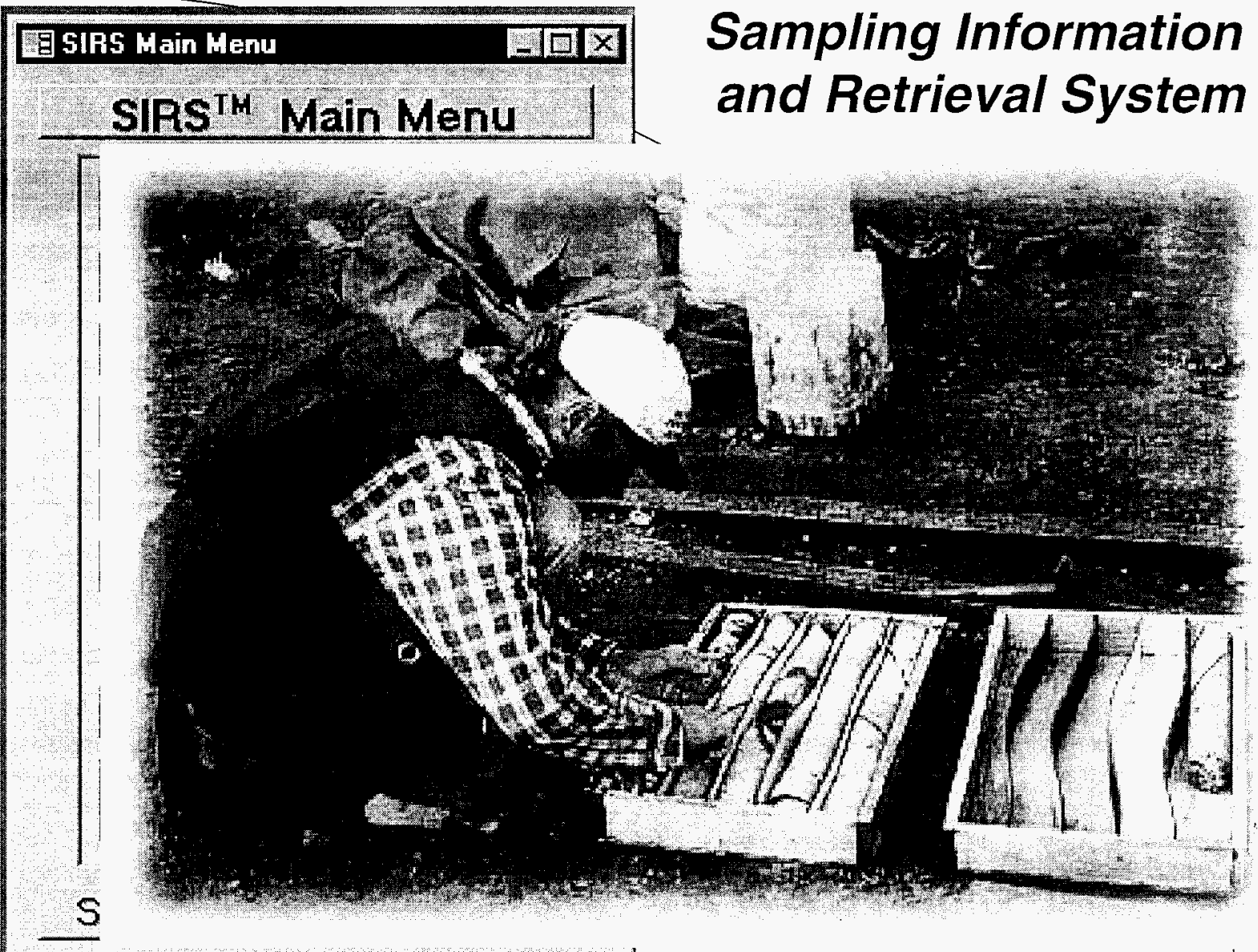




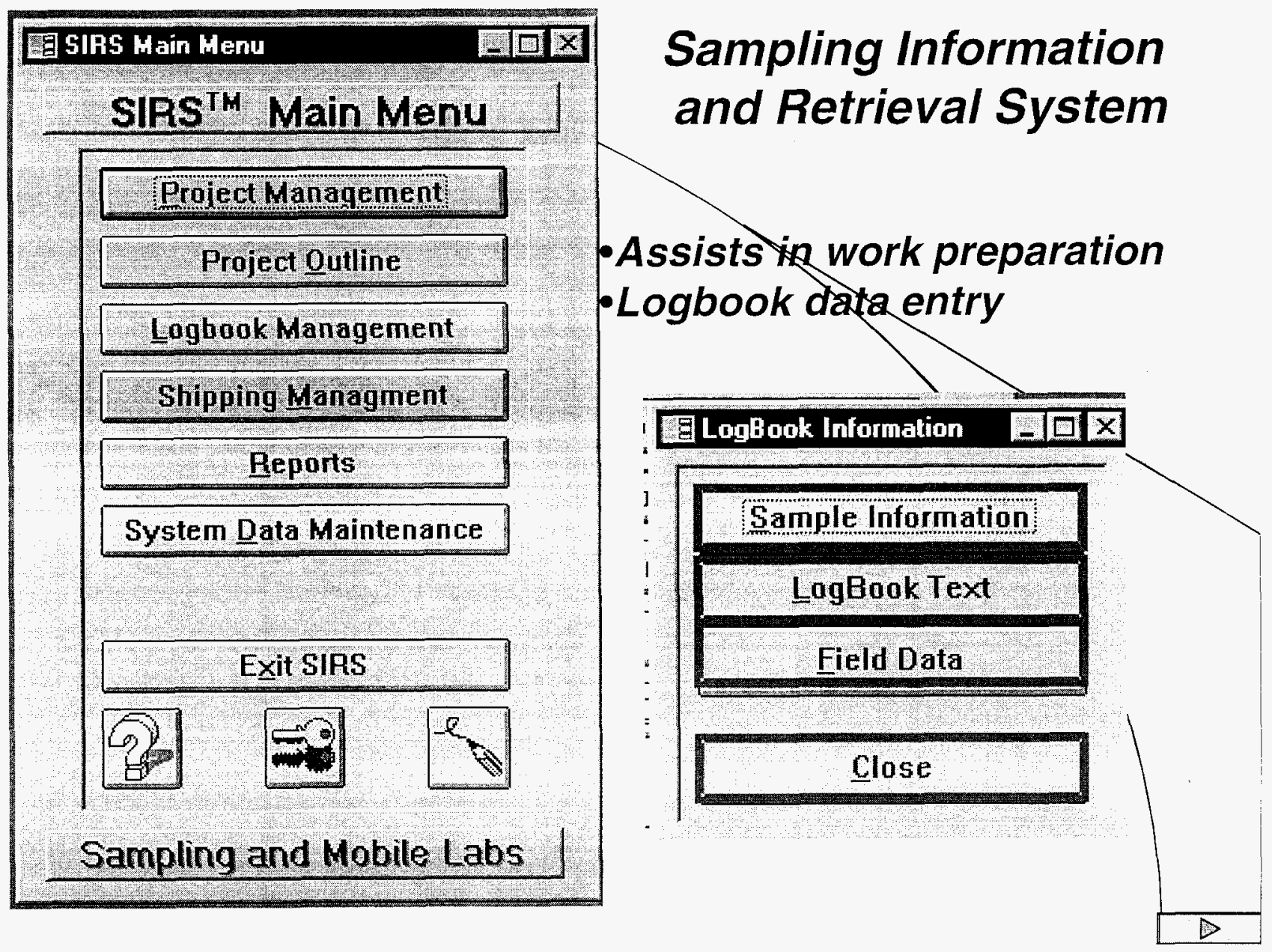









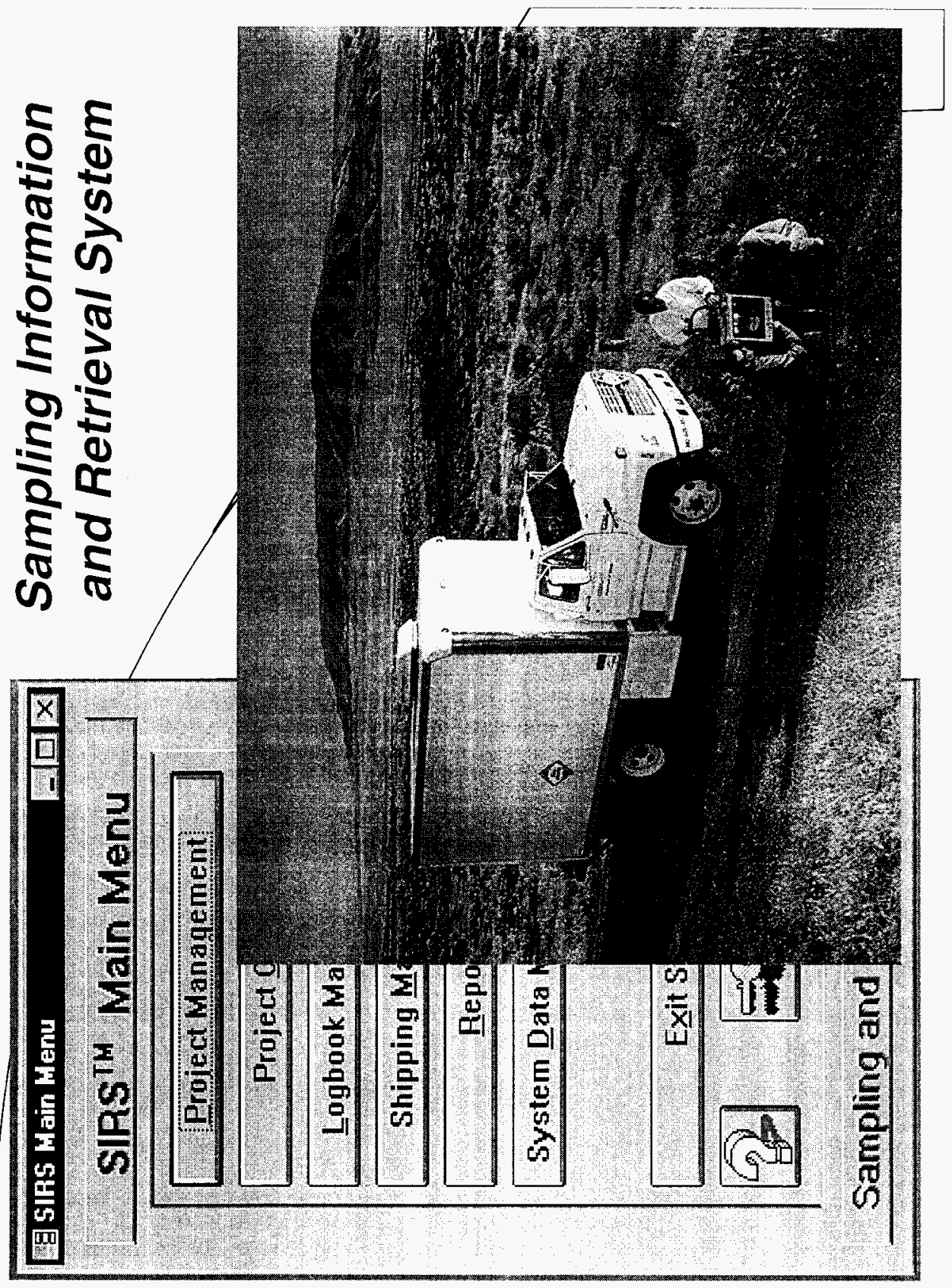




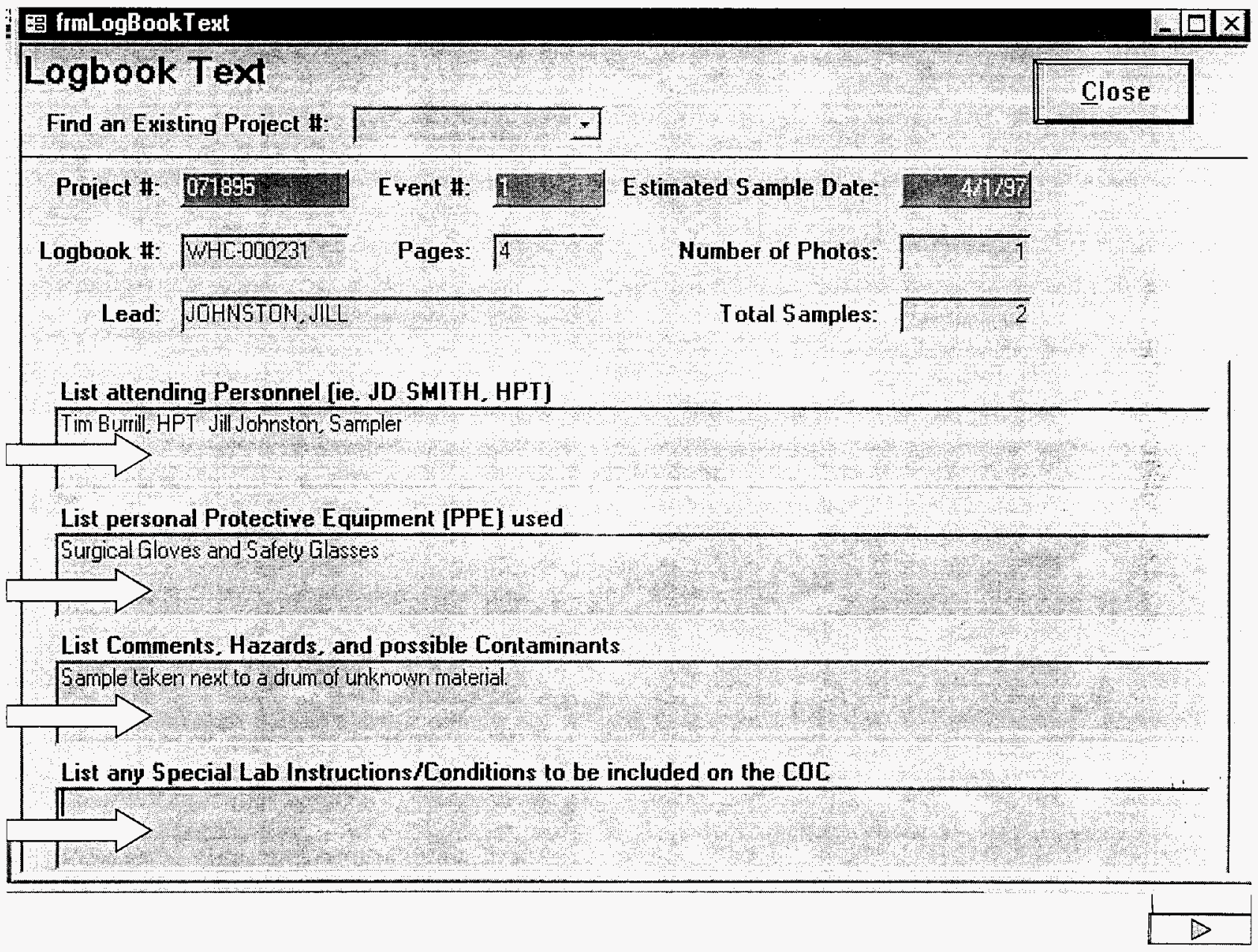




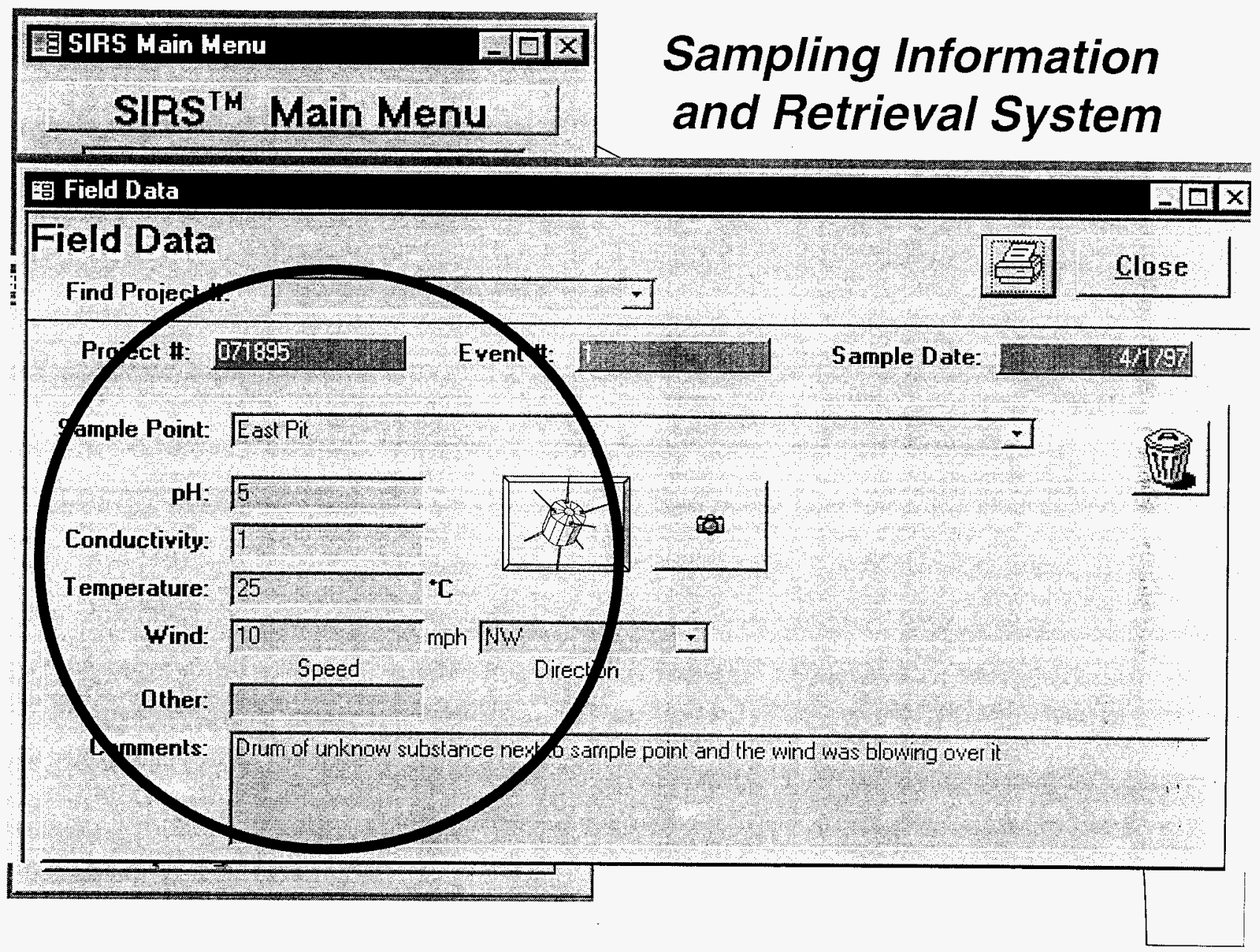




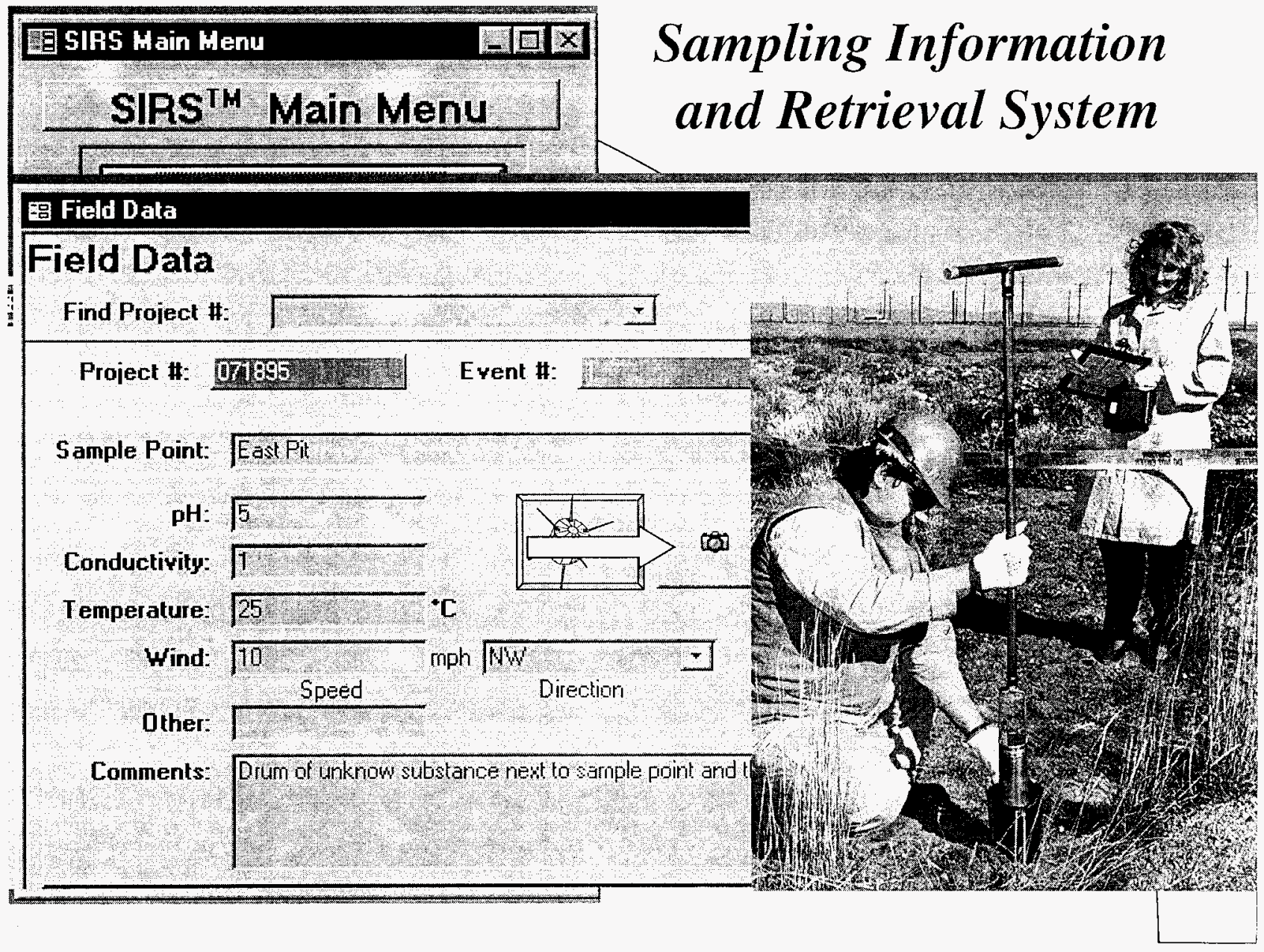




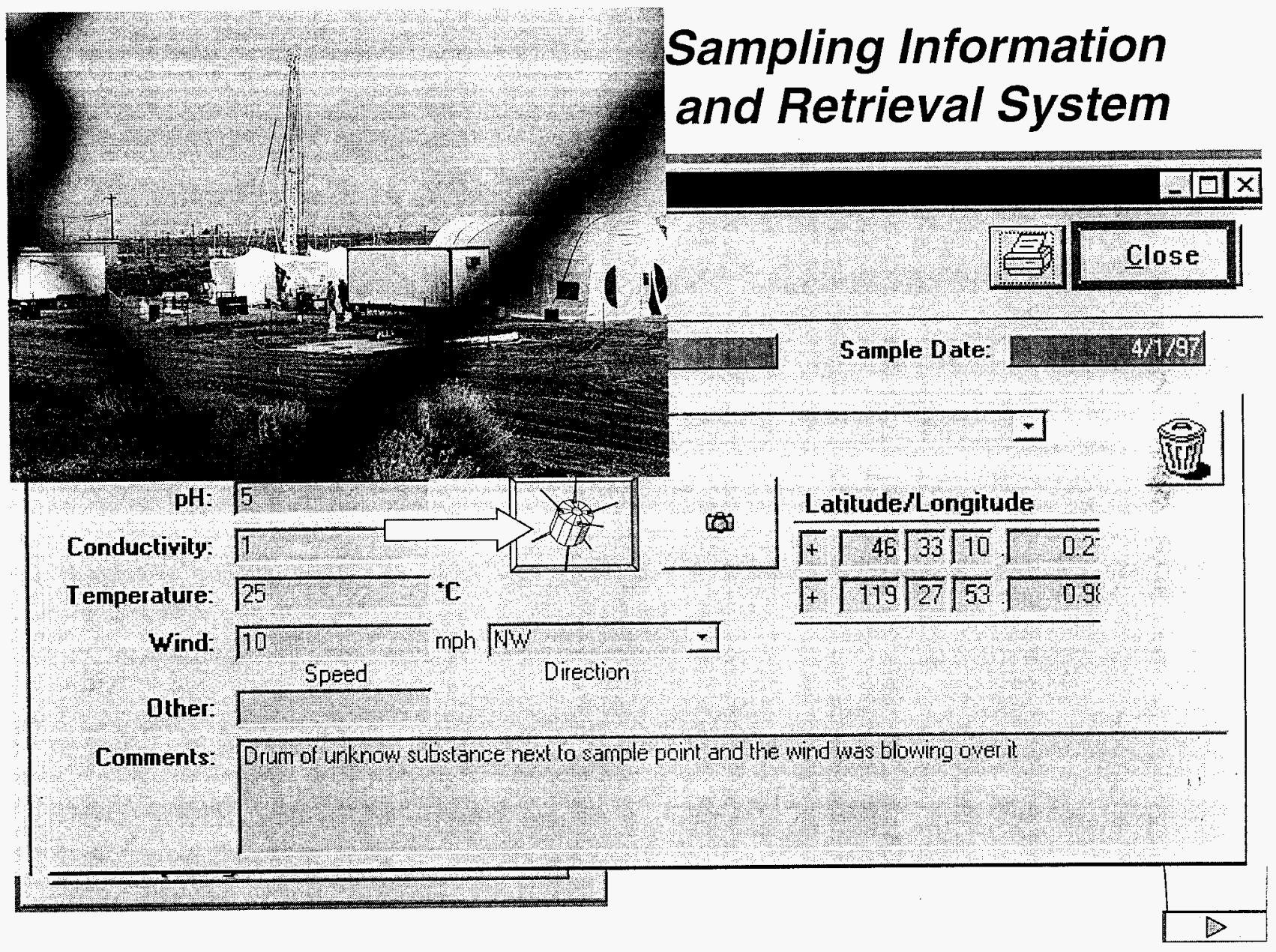




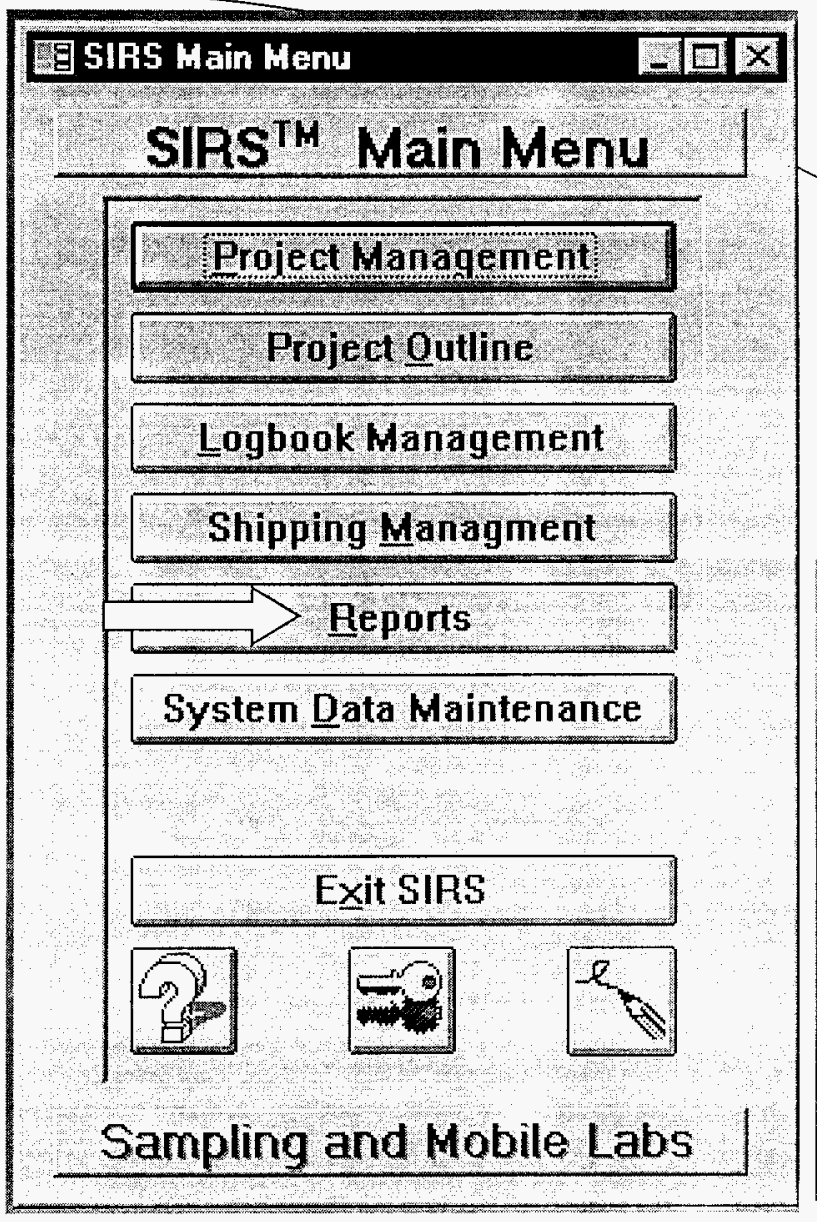

\section{Sampling Information and Retrieval System}

-Produces documentation

- Labels

- Chain of Custody

- Shipping docaments

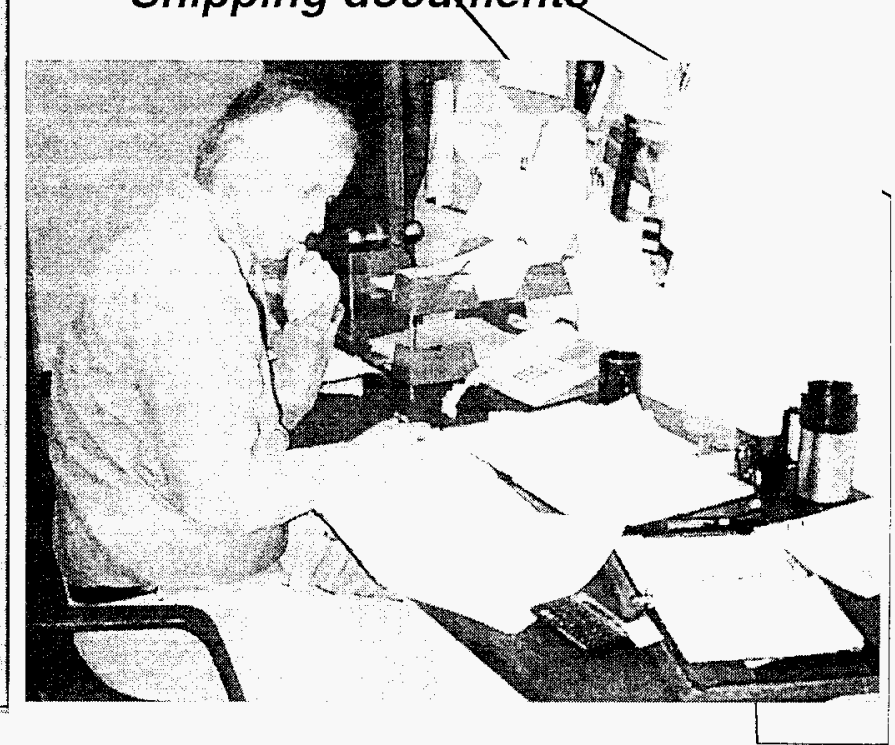




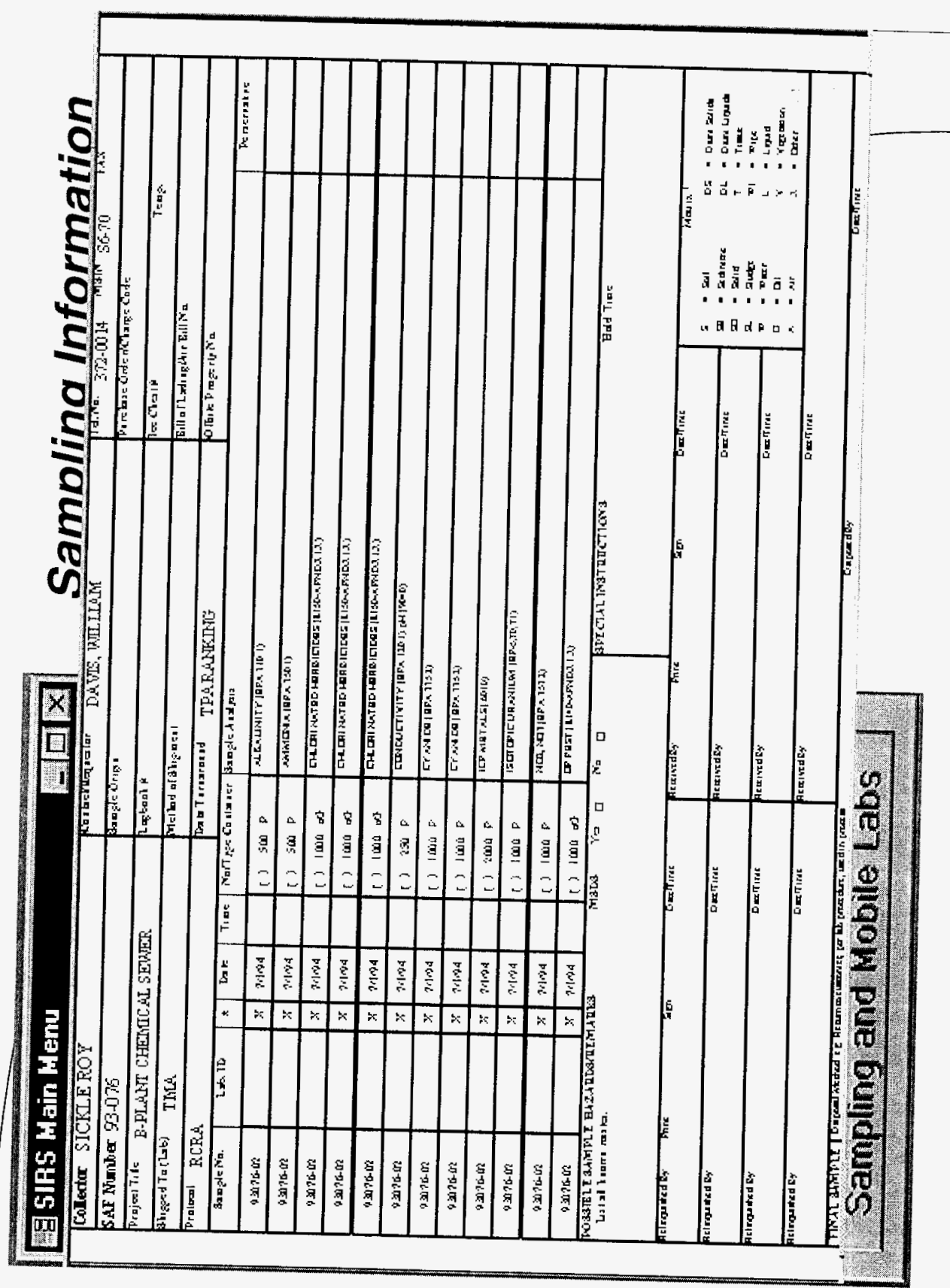




\section{圆SIRS Main Menu E[D圂 Samblina Information}

Westingh ous e Hanford Company

\section{Sample Point information Report}
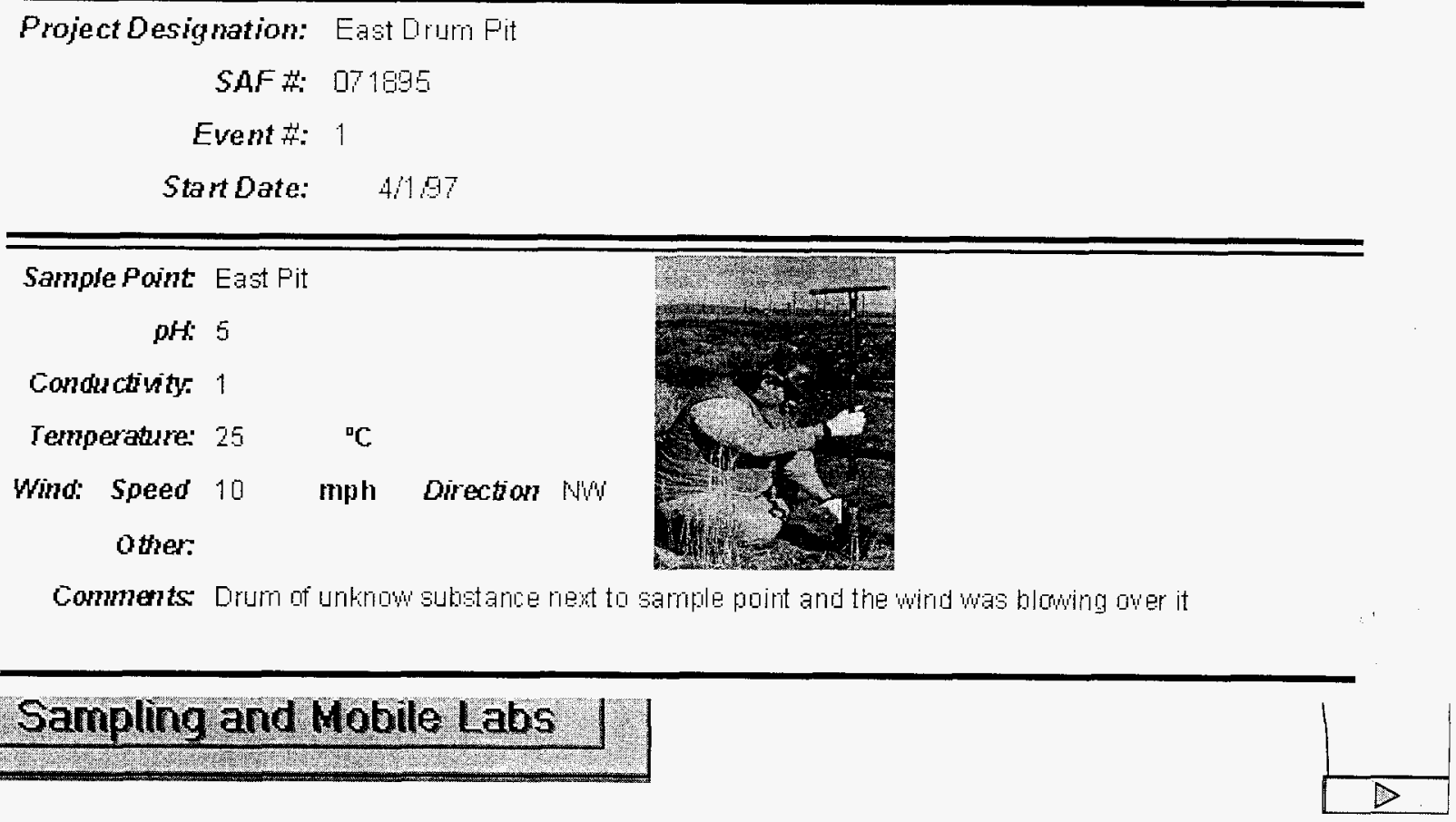


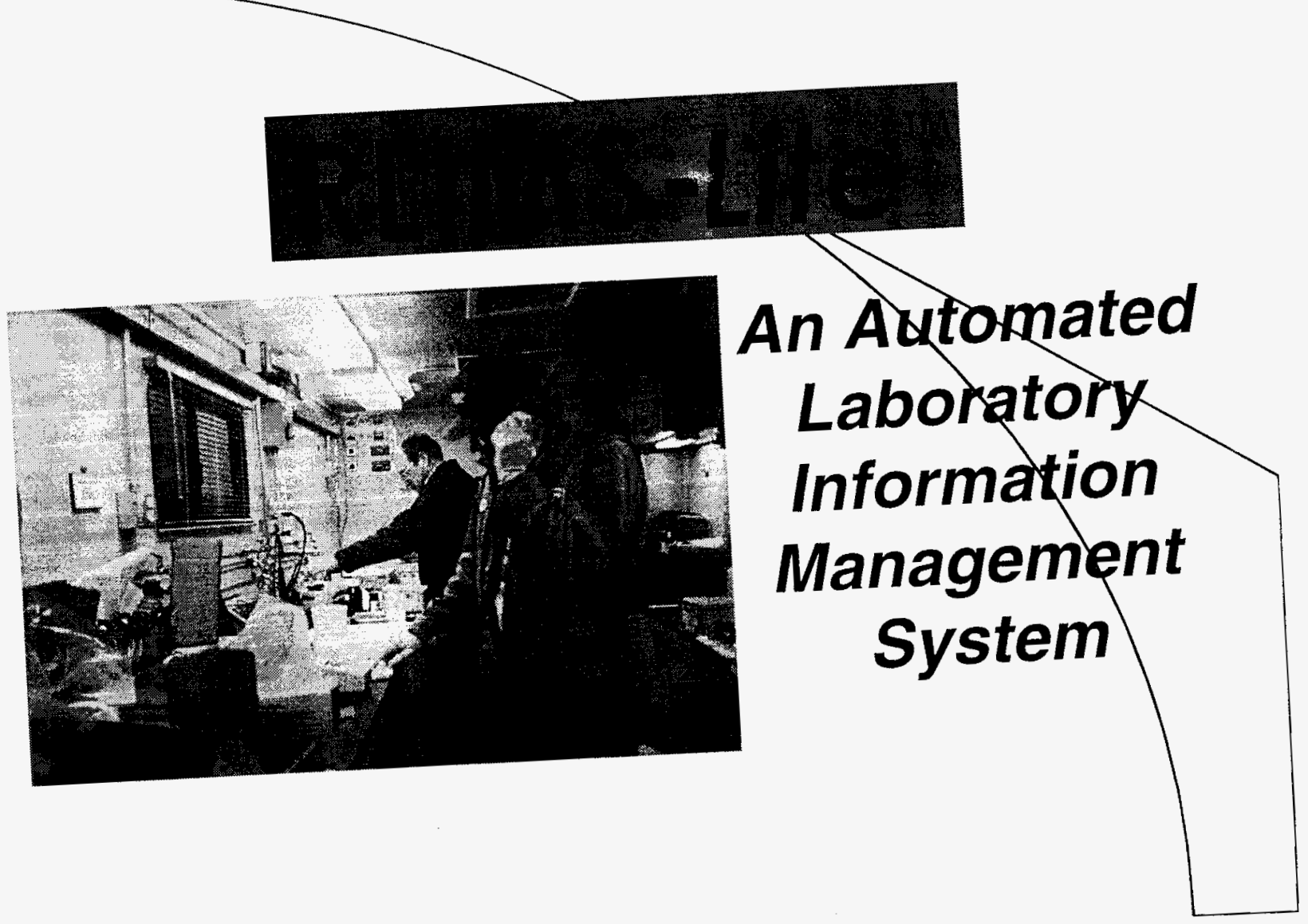




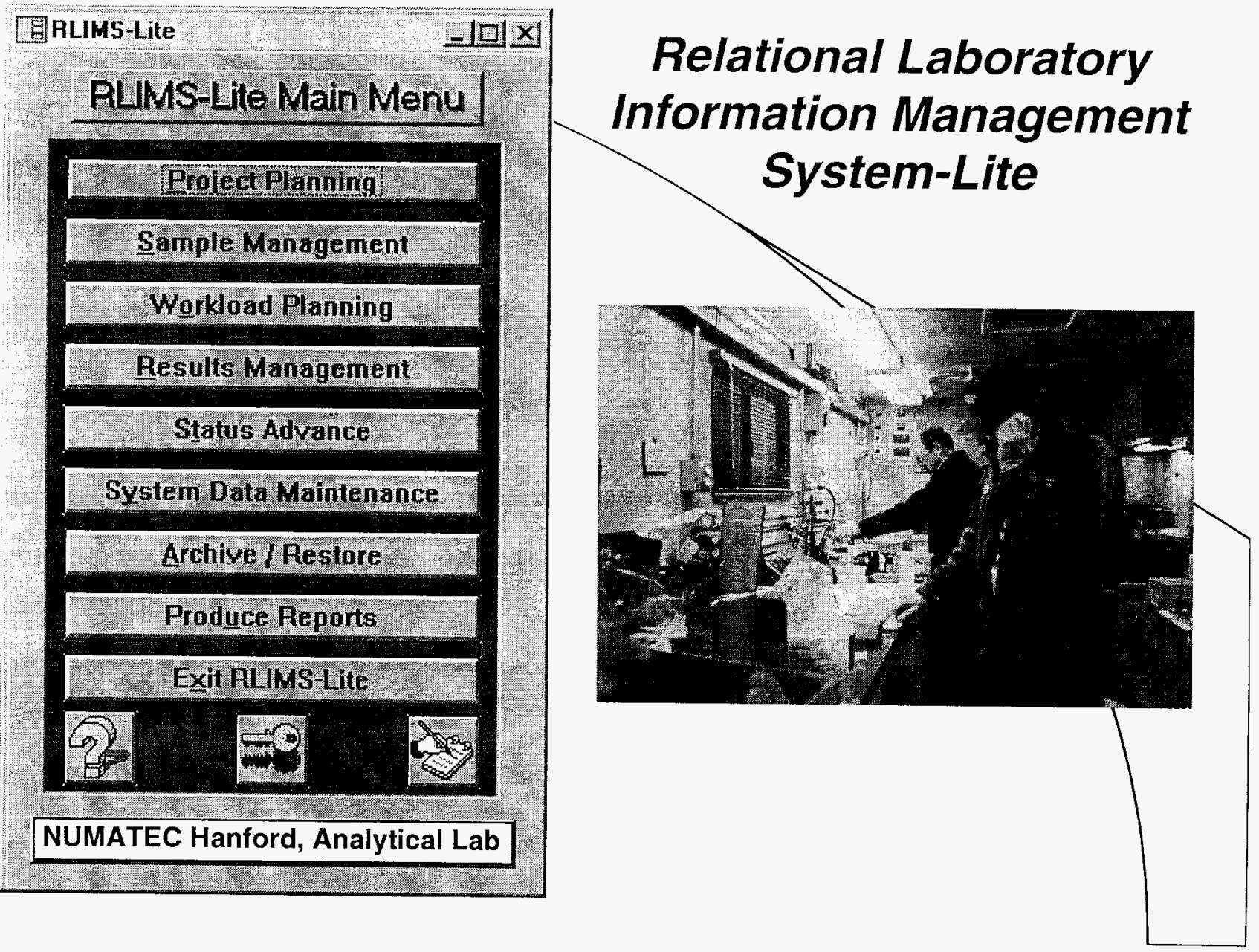


RLIMS-Lite Main Menu

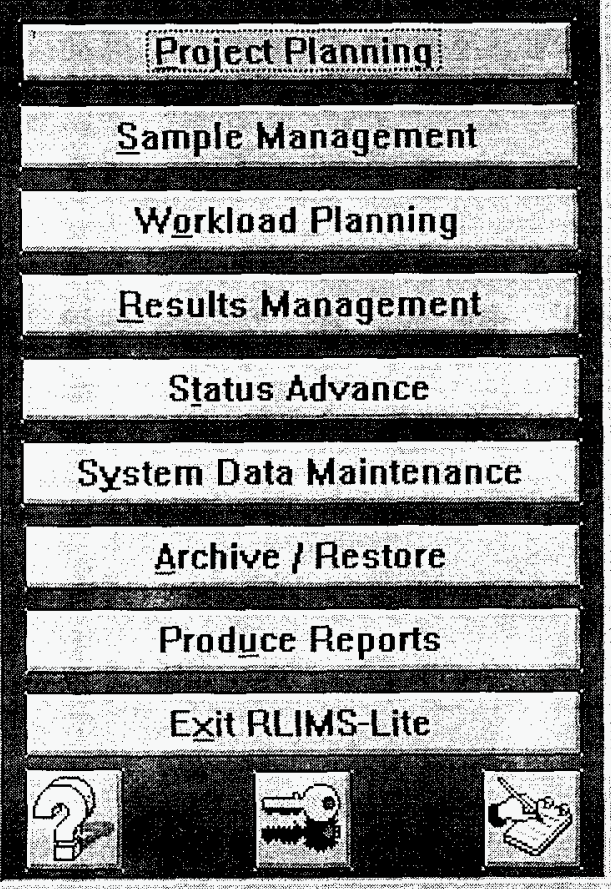

NUMATEC Hanford, Analytical Lab
Relational Laboratory Information Management System-Lite -Pre-planning / Sales -Sample Receiving -Sample Preparation -Sample Analysis -Quality Control -Sample Reporting - Lab Management 
Based Upon EPA's

$R L I M S$ Orac
Database

Re-Engineered

Using Microsoft

Access 


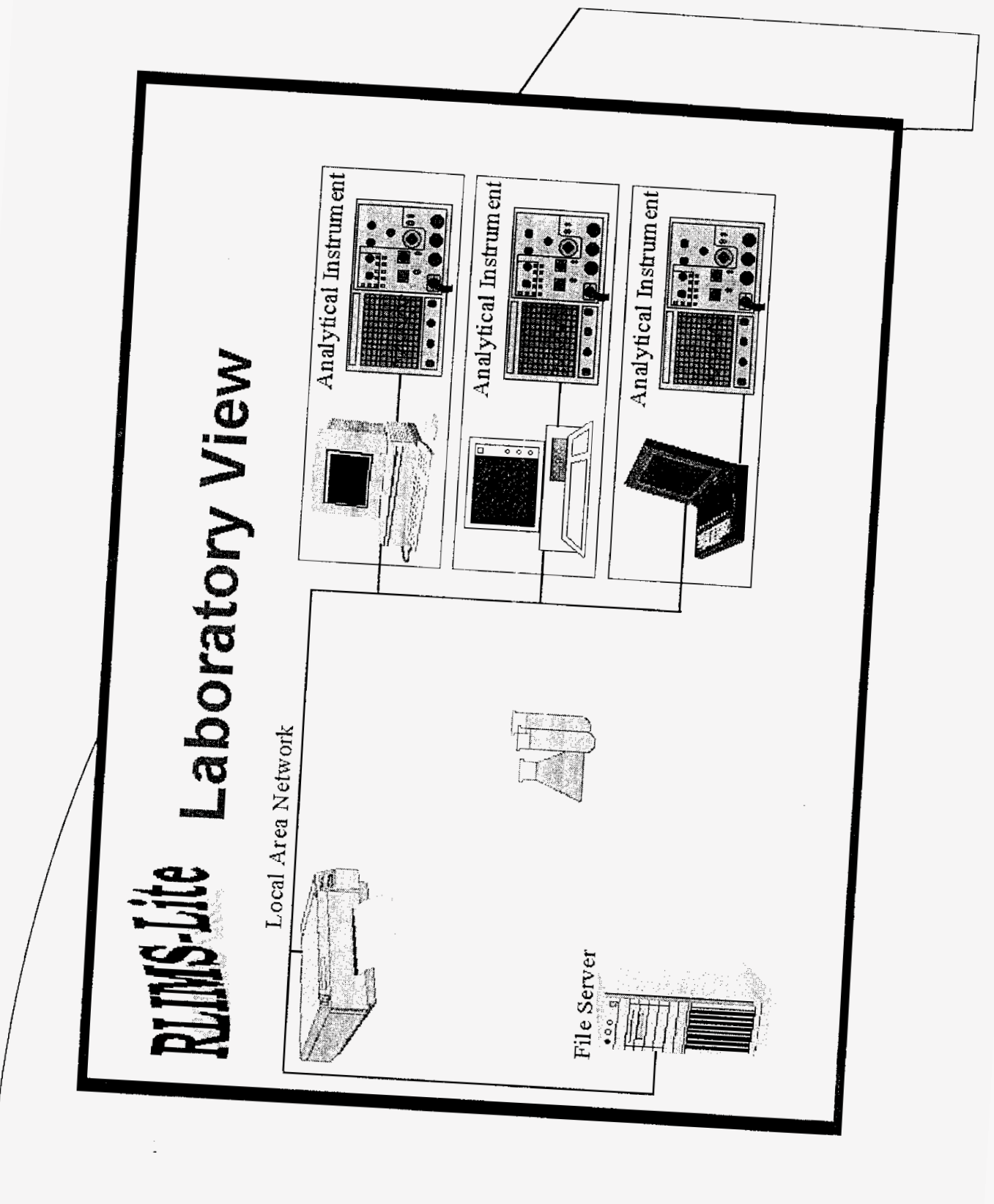




\section{RLIMS-Lite Main Menu}

\section{LE Project Planning}

andistas
Relational Laboratory Information Management

System-Lite

G Project Maintenance

\section{Project Maintenang}

Status: APFROVED -

.7 Facility: East Pit

Priority:

Comments:

ROUTINE

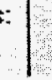

$-10 x$

Project An iyses:

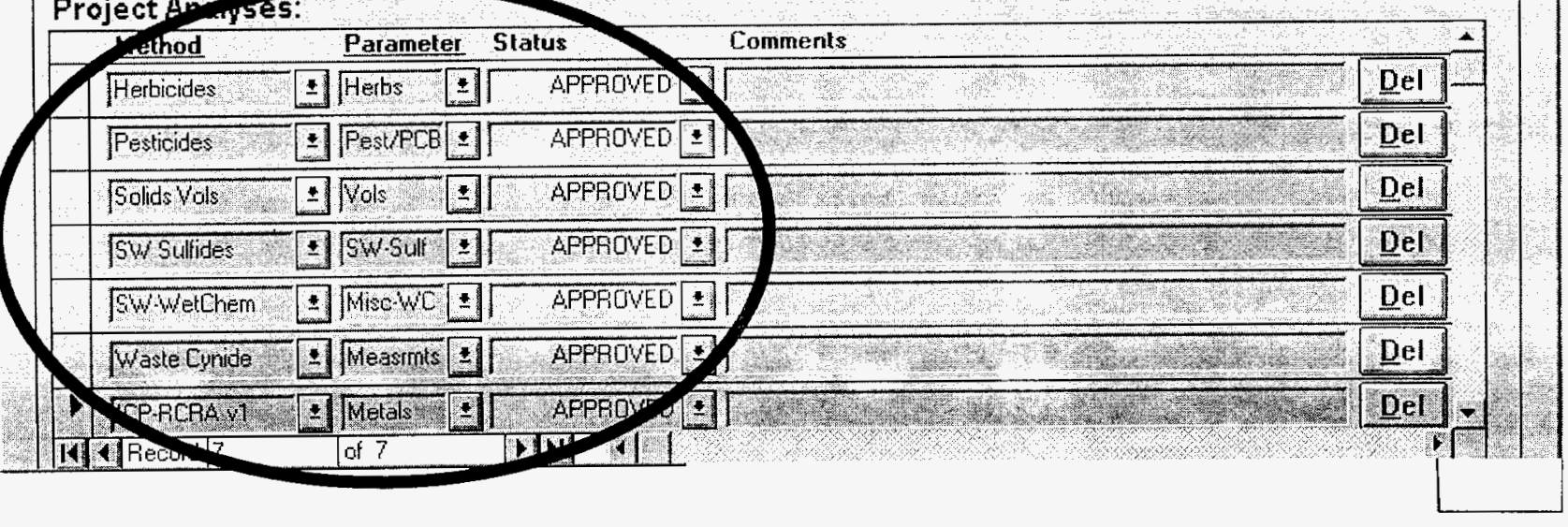




\section{FILIHS-Lite \\ $-\mid \square] x \mid$ \\ RLIMS-Lite Main Menu \\ Log Proiect Planning \\ Relational Laboratory Information Management System-Lite}

B Project Haintenance

므미

Project Maintenance Select Project ID: East Drum Pit

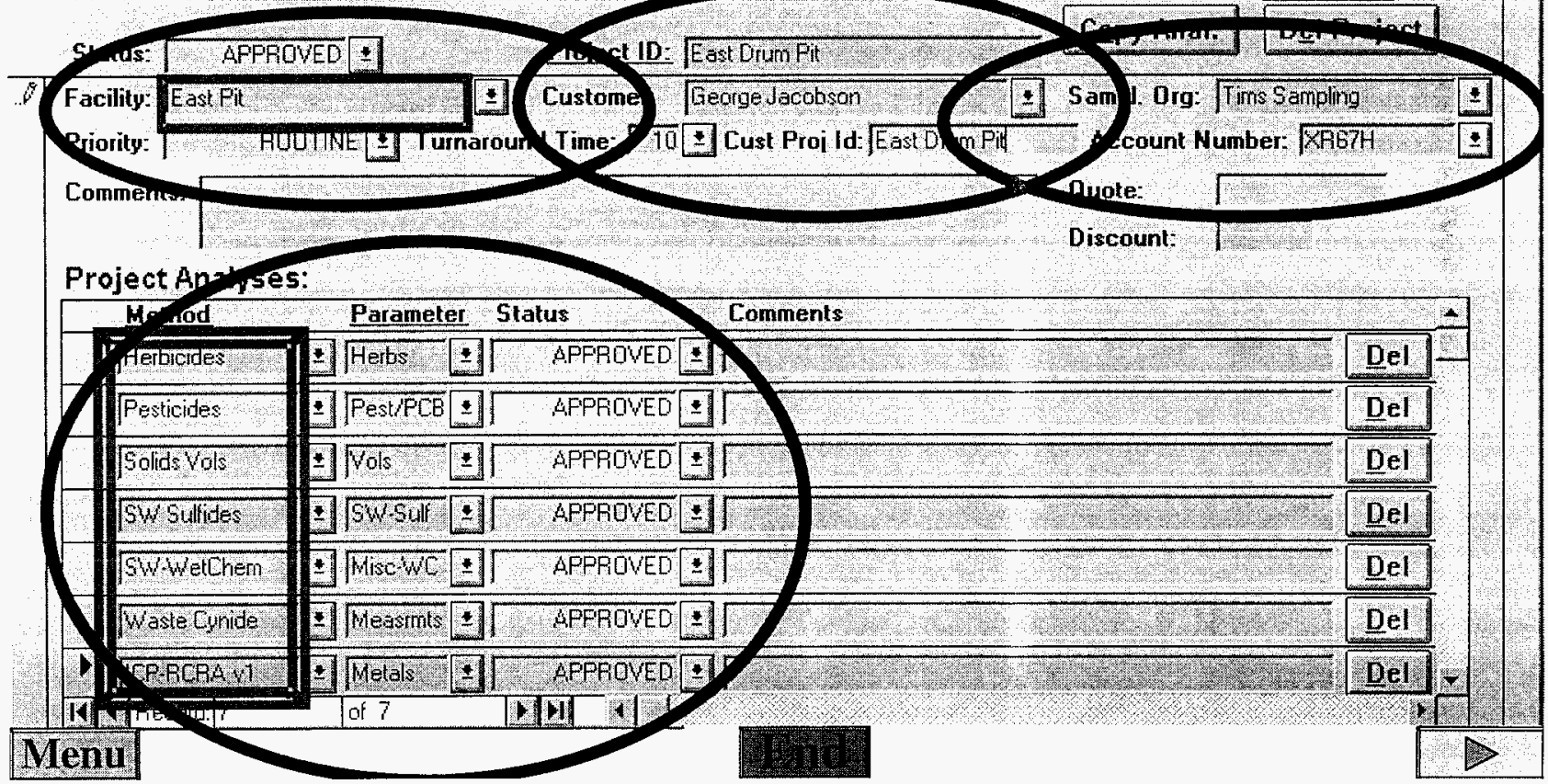




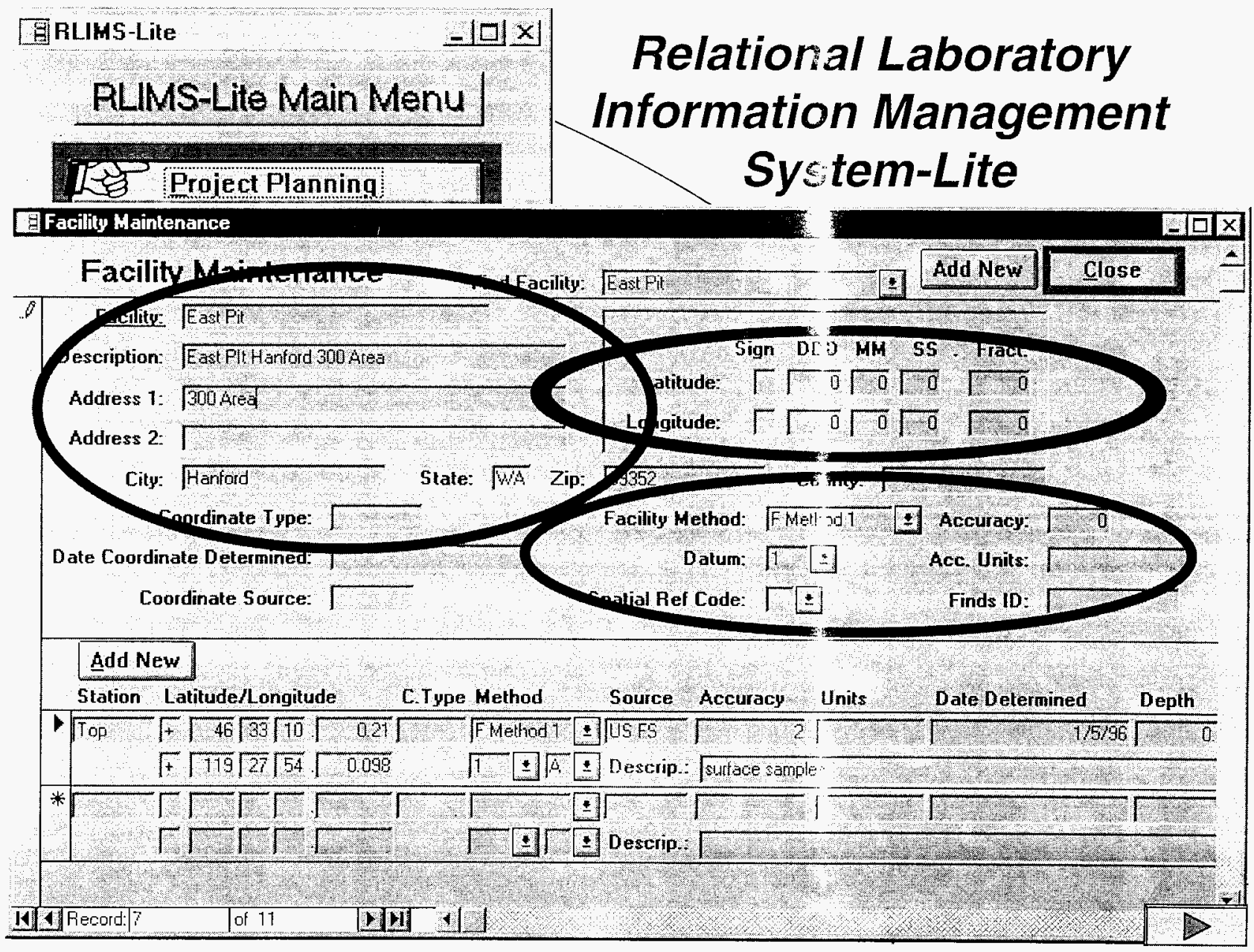




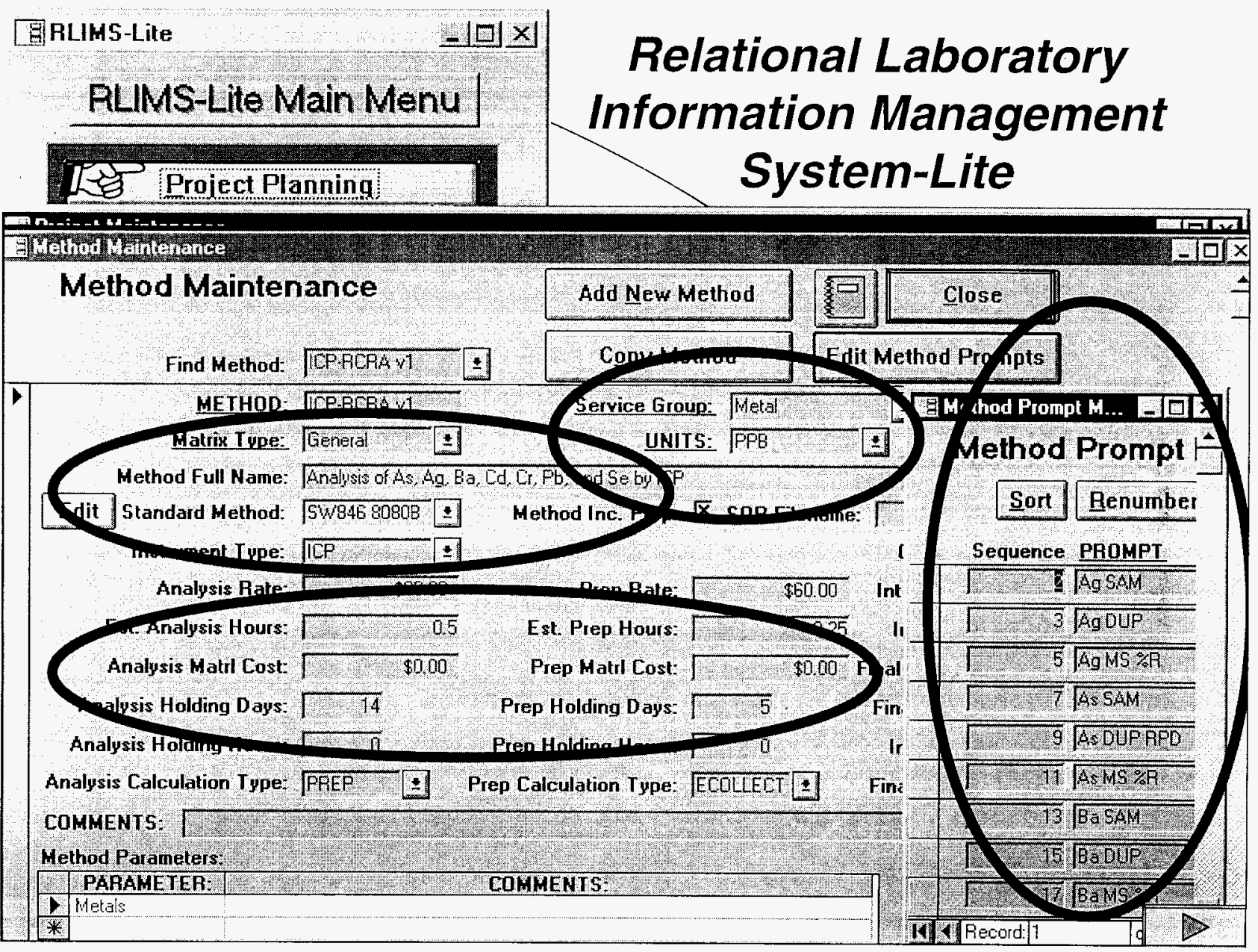




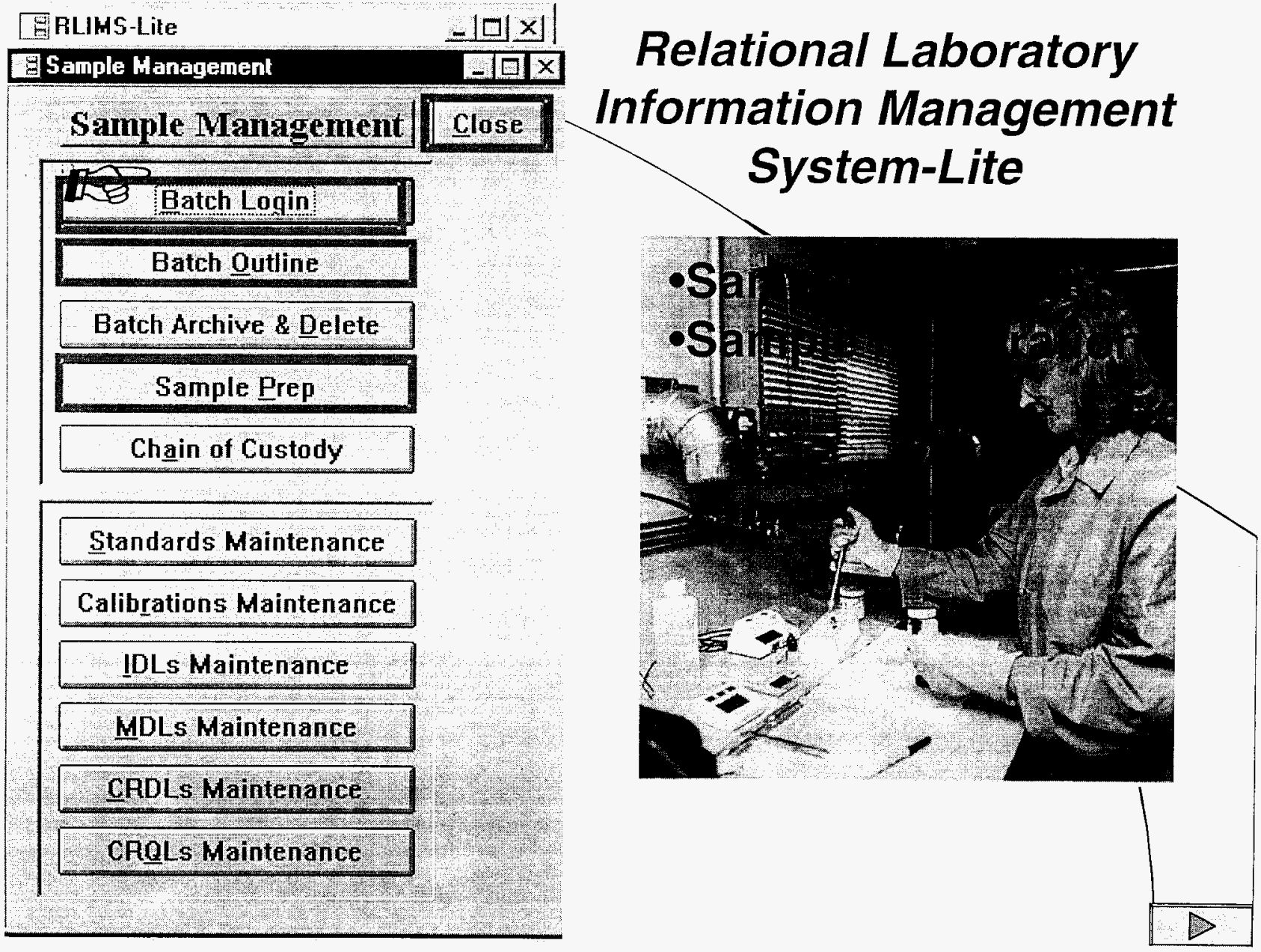




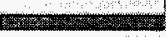

g Sample Management Sample Management Close Iation Management

G Batch Login

\section{Batch Login}

Find Sample Hairs in. Wantoine

\section{Add New Batch}

Bar Code Labels

$-a x$

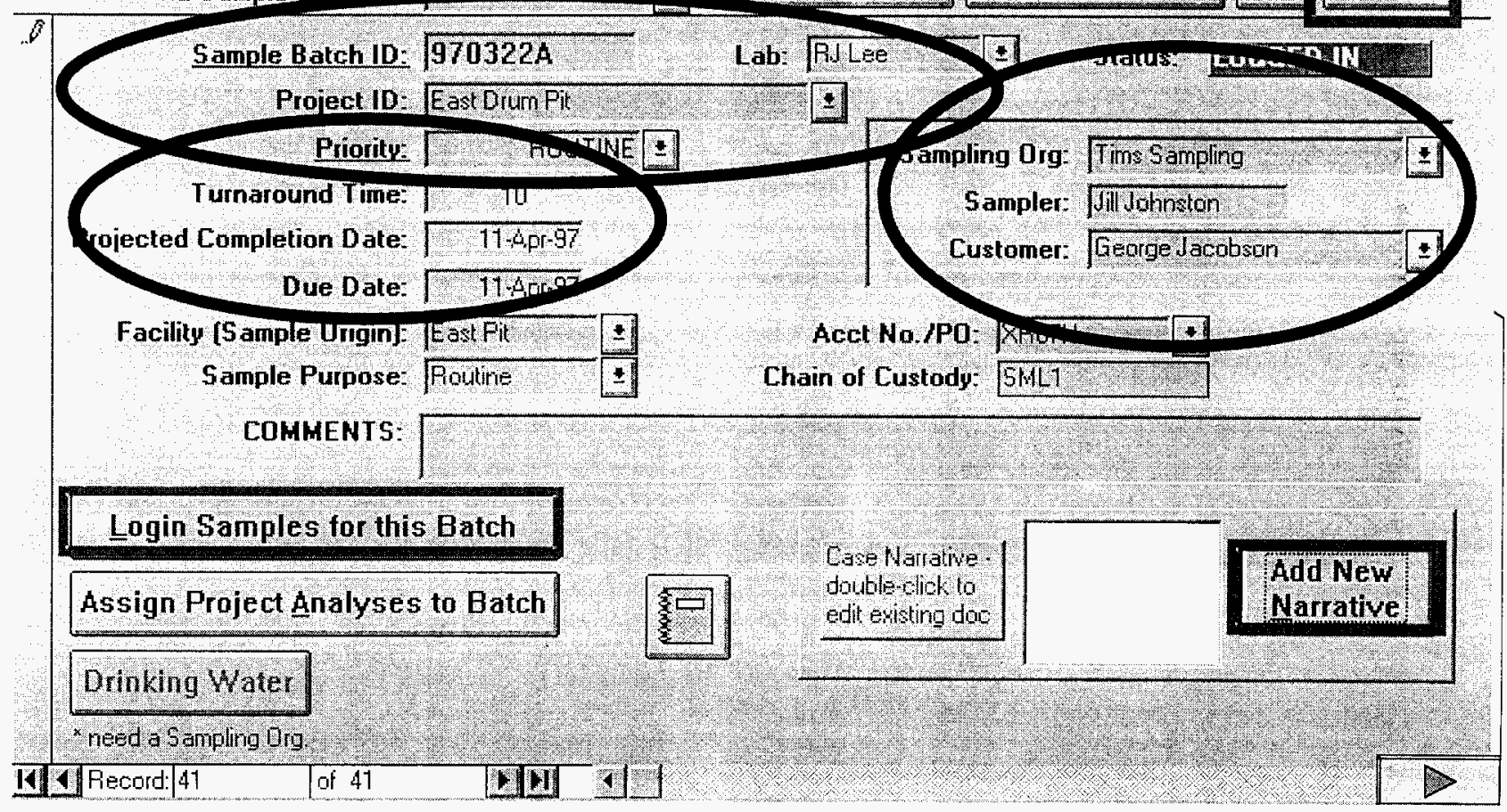




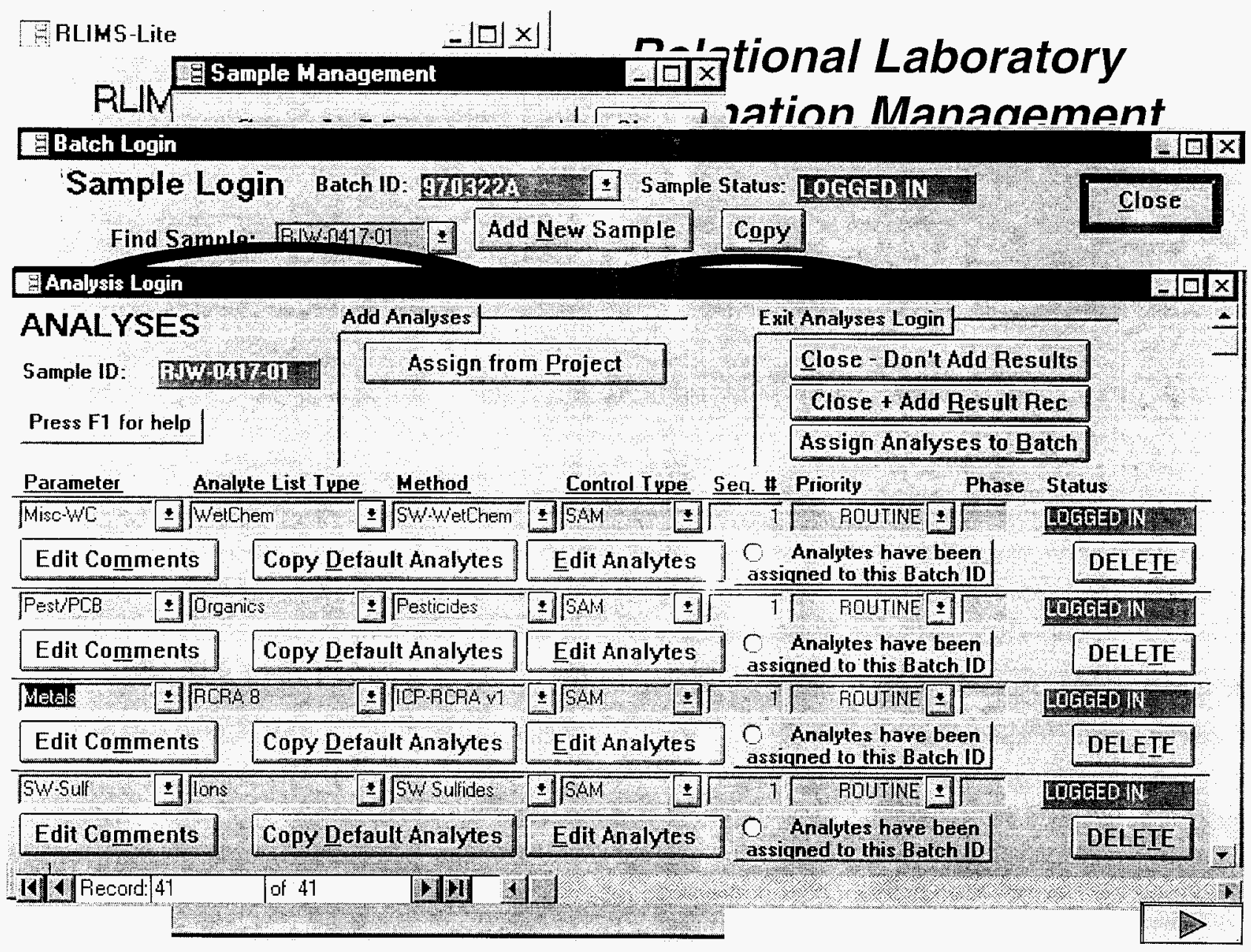




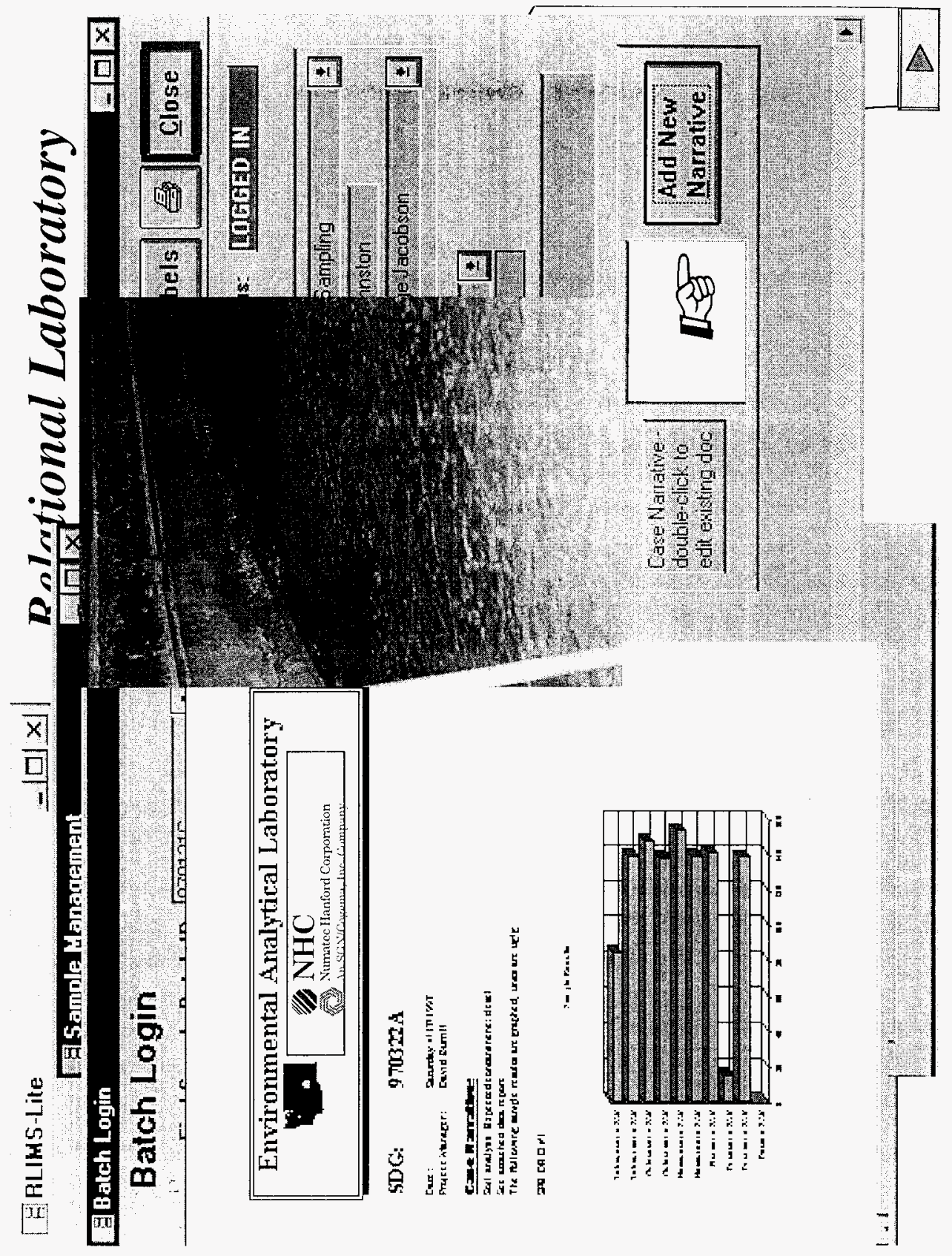




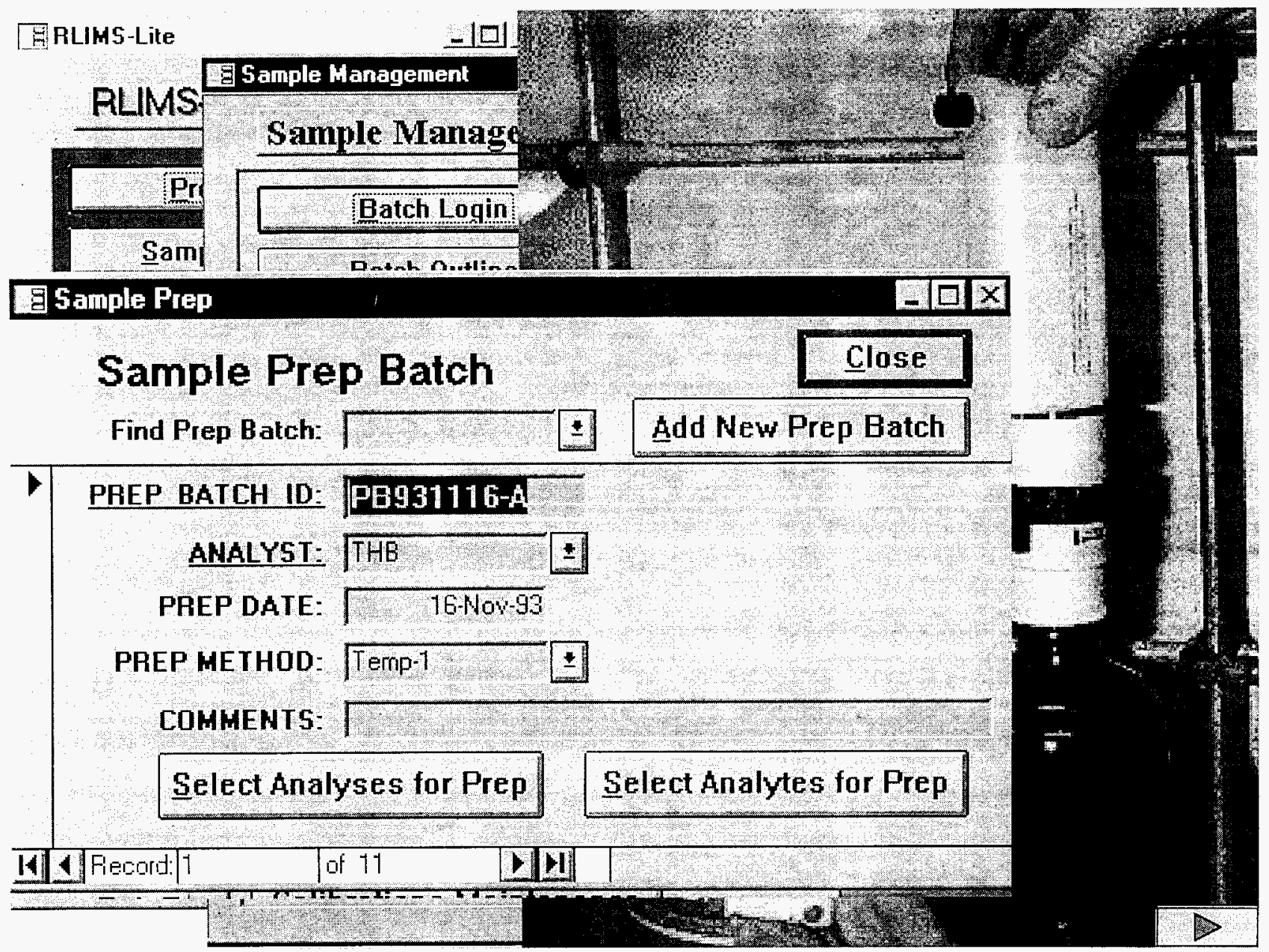




\section{GFLIHS-Lite \\ ni In te ta 5 ample Management

$$
-\mid[|\mathrm{x}| \mathrm{x} \mid
$$

Batch Outline View Click +' to expand. '- to collapse, double click on batch ID to fully expand a batch

T\$51227A

$+951019 \mathrm{~A}$

$-941213 A$

- MINERALSI

4 Anions

t Anions

- Anions

$$
\begin{aligned}
& \text { CI SAM } \\
& \text { F SAM } \\
& \text { NOS SAM } \\
& \text { PO4 SAM } \\
& \text { SO4 SAM }
\end{aligned}
$$

s MINERALS II COMPLETE
\& $941209 \mathrm{~A}$

\& $941201 \mathrm{~A}$

\& $941102 \mathrm{~A}$

f $970131 B$

if 9703144

$+970304 \mathrm{~A}$

t5 970131A

\& 9604296

\& $960429 B$

क $941130 \mathrm{~A}$

it $941117 \mathrm{~A}$

\&970131C

$\begin{array}{ll}\text { John Wayne } & \text { LOGGED IN } \\ \text { John Wayme } & \text { COMPLETE } \\ \text { John Wayne } & \text { COMPLETE }\end{array}$

COMPLETE

DUP

MS

SAM

- John Wayne John Wayne John Wayne

$1.69 \mathrm{E}+02 \mathrm{ug} / \mathrm{ml}$

$0.09 \mathrm{E}+00 \mathrm{ug} / \mathrm{ml}$

$0.00 E+00$ yg/ml

0.00E 100 ughrol

$688 \mathrm{E}+01$ ugh

\section{LOGGED IN}

LOGGED IN

COMPLETE

MR. CHUCK NORAIS, COMPLETE

MR DON CARSON LOGGED WN

MR. DOH CARSON LOGGED IN

MR. DON CARSON IN PROGRESS

Mr. Long

Mr. Long

Mir. Long

Mr. Long

MR. PAUL ZIES
IN PROGRESS

IN PROGRESS

COMPIETE

LOGGED IN

COMPLEIE 


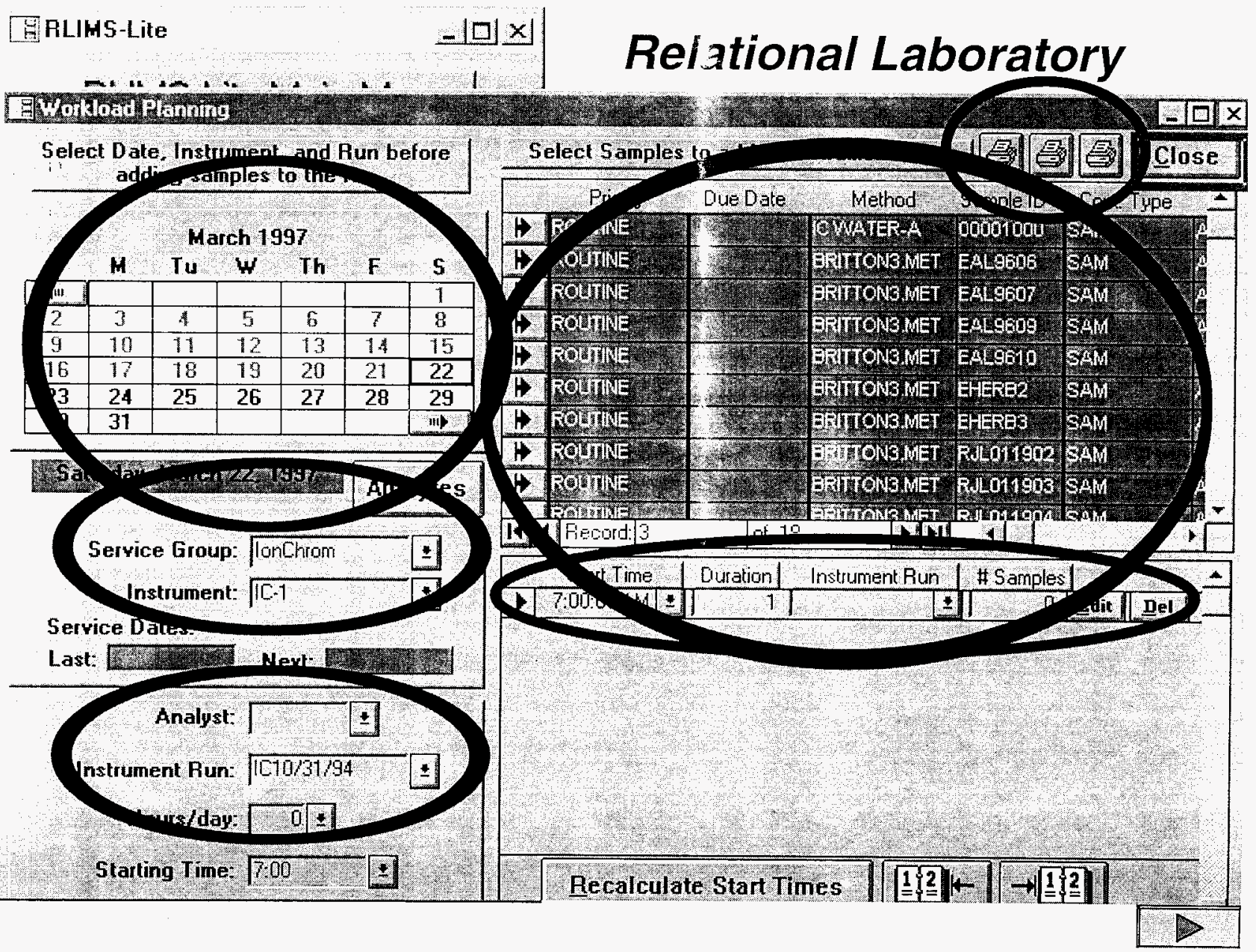


RLIMS-Lite Main Mer

\begin{tabular}{|c|}
\hline Project Planning \\
\hline Sample Management \\
\hline Workload Planning \\
\hline Gesults Management \\
Status Advance \\
\hline
\end{tabular}

System Data Maintenance

Archive / Restore

Produce Reports

Exit RLIMS-Lite

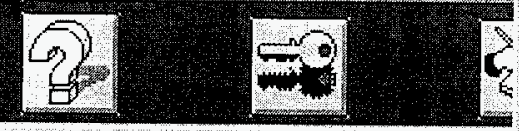

NUMATEC Hanford, Analytica
Results Management

Close

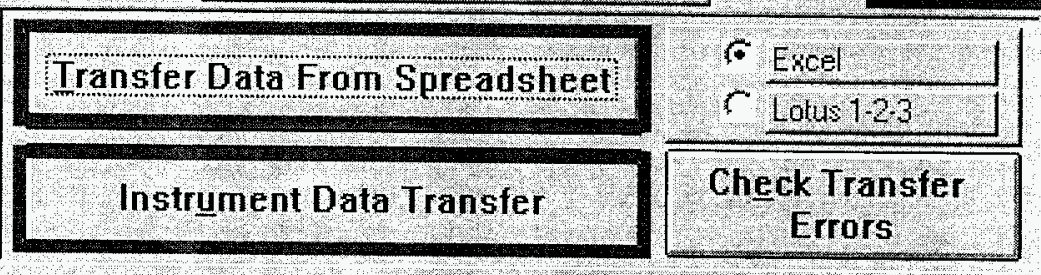

Manual Results Entry by Sample

Select Batch ID

Manual Results Entry by Batch

国

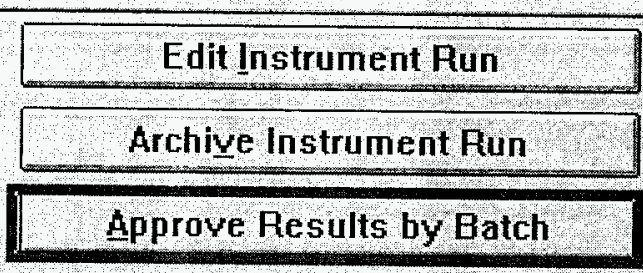

Approve Results by Inst. Run

TIC Results Entry

Wastewater Treatment 
RLIMS-Lite Main Mer

Results Management

Close

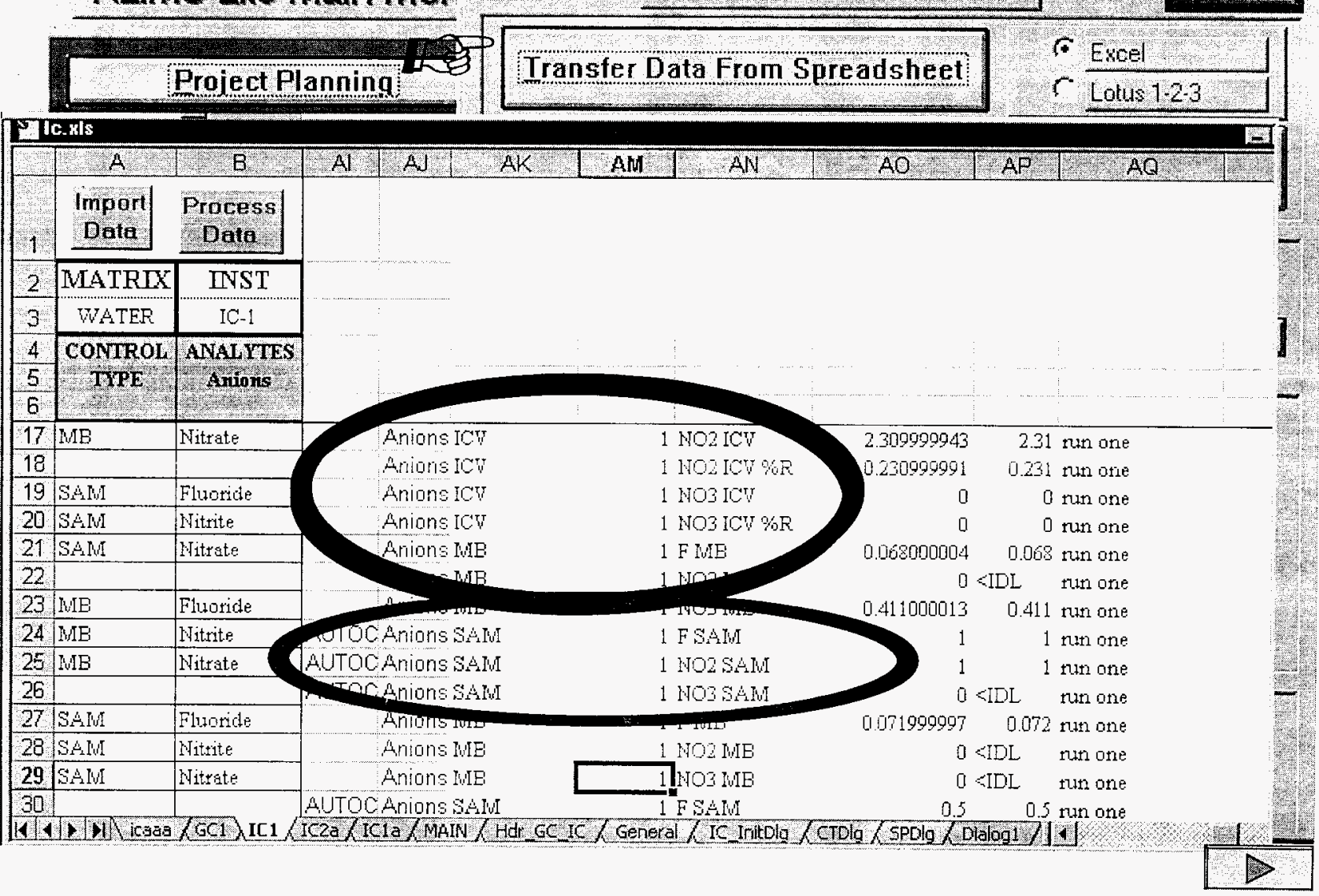




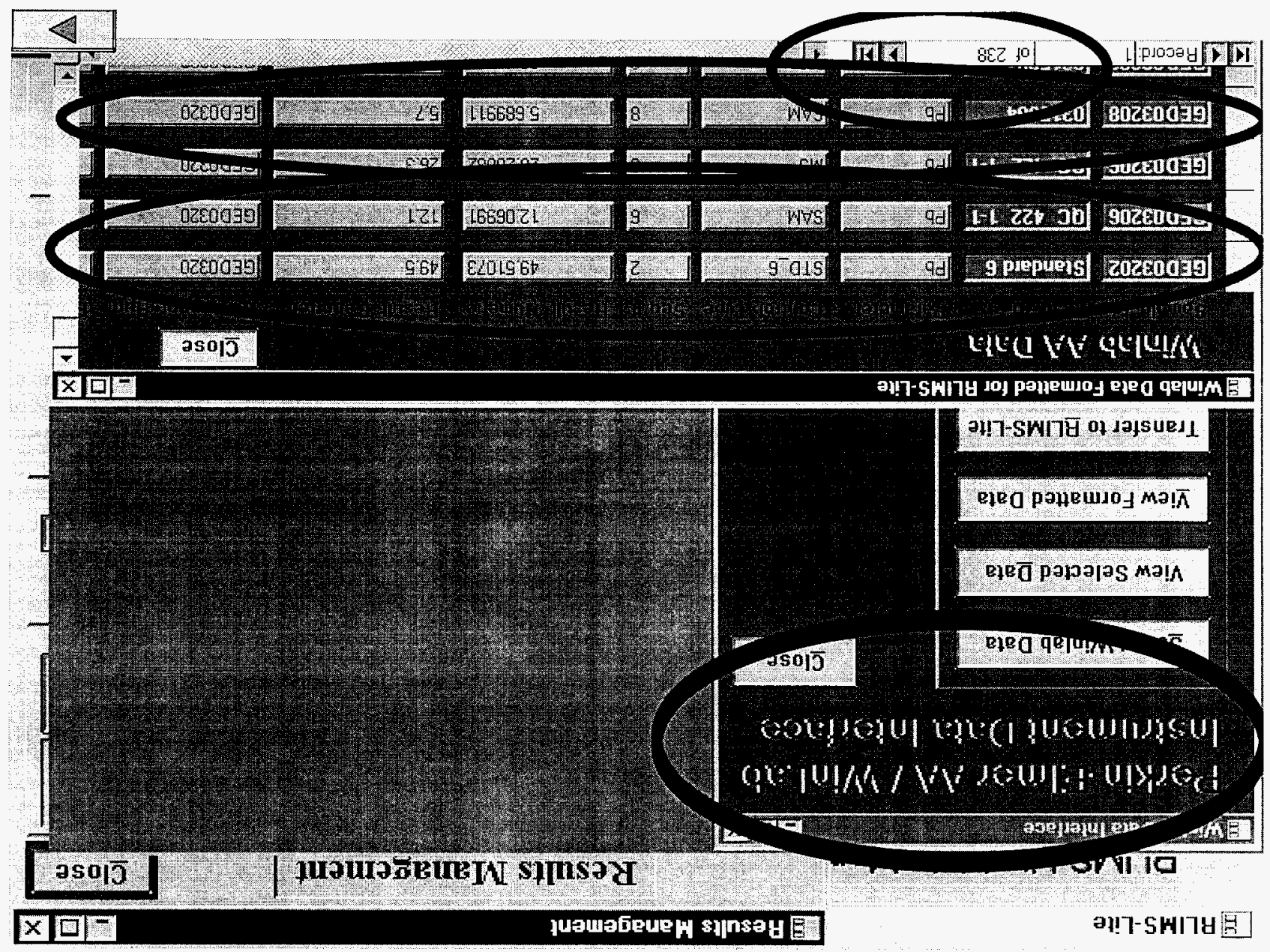




$$
-|0| x \mid
$$

PLIMS-Lite Main Menu

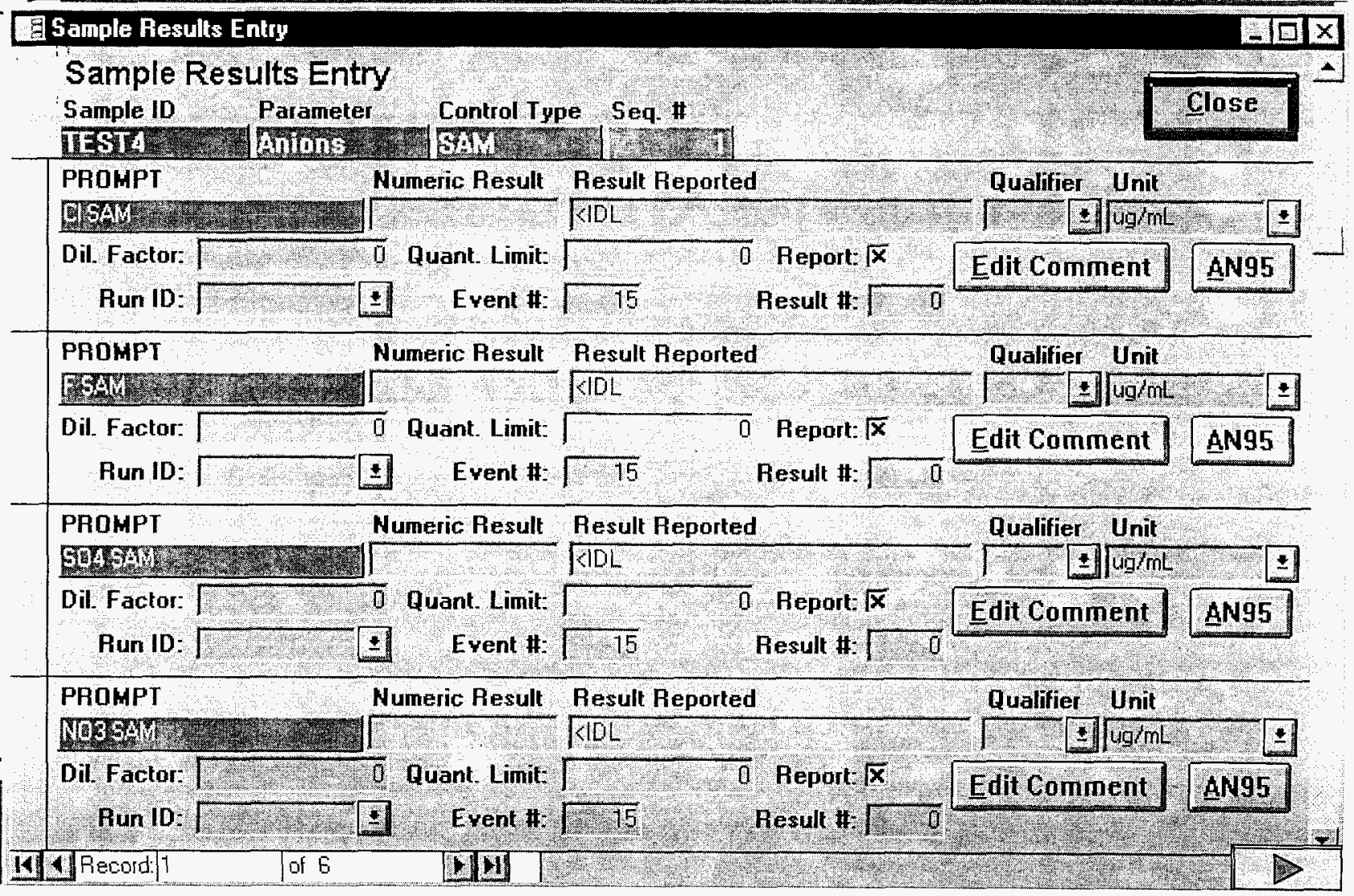




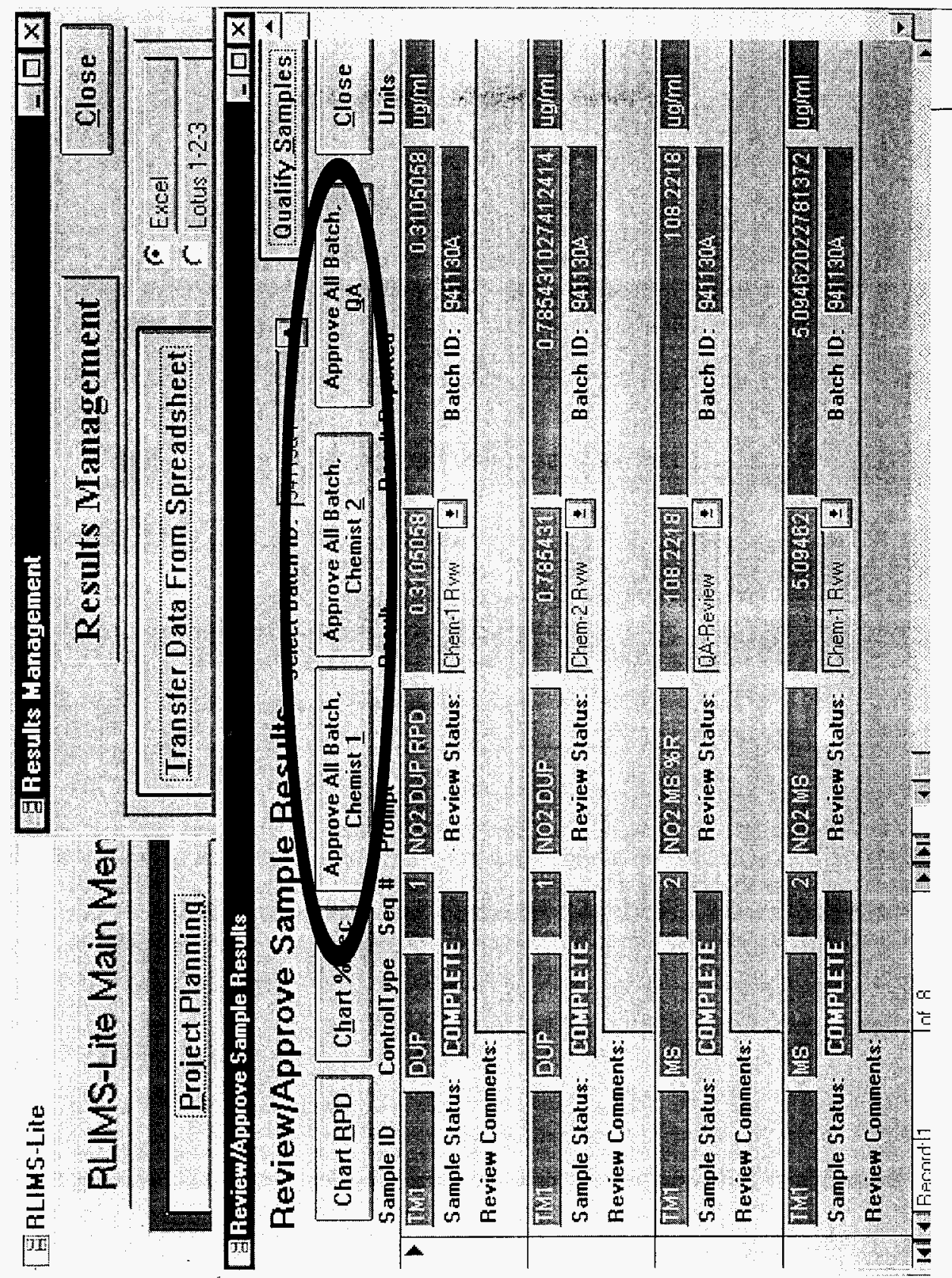




\section{Results Management}

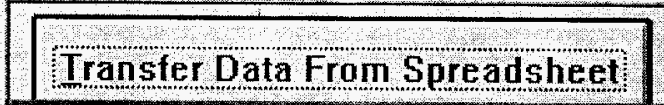

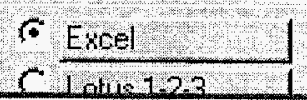

G Aeview/Approve Sample Results

Review/Anorove Sample Results select Batch ID: 9411304

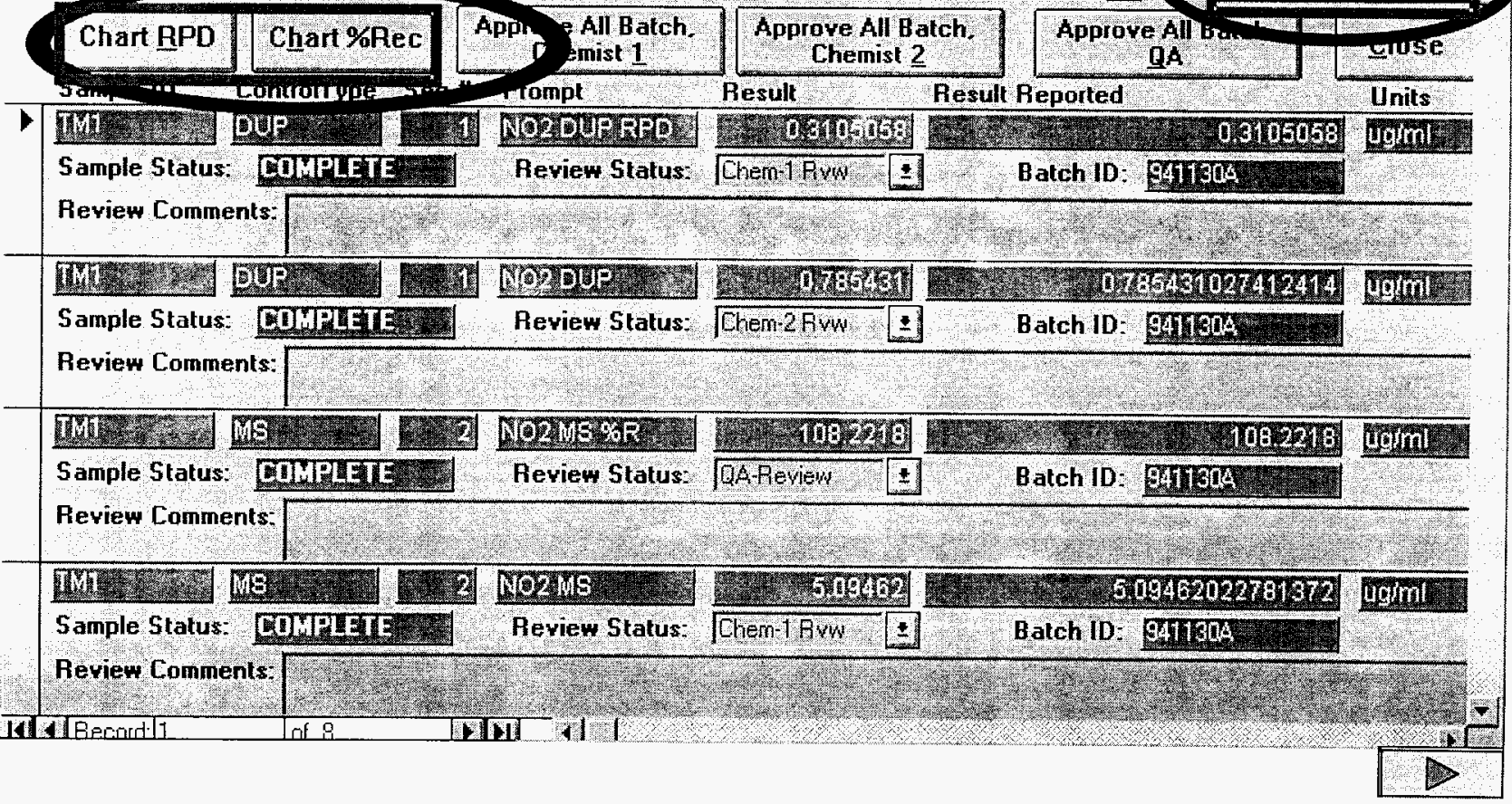


RLIMS-Lite Main Mer

\section{Results Management}

G Aeview/Approve Sample Results

Review/Approve Sample Results Select Batch ID: 9411306

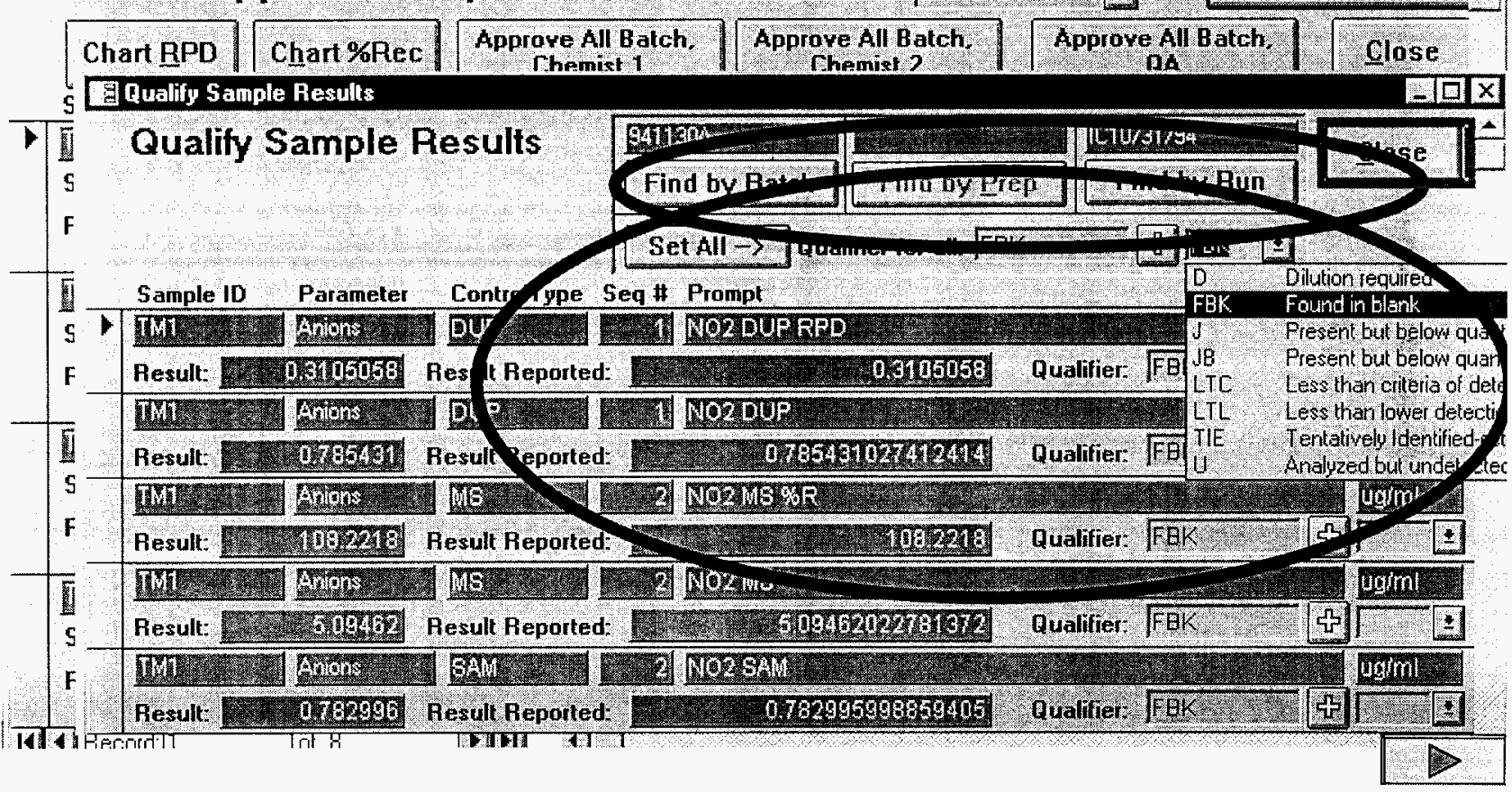




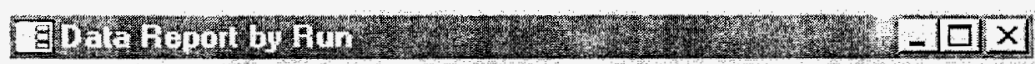

Chart Relative Percent Difference Close

i.

Select Analyte: 504

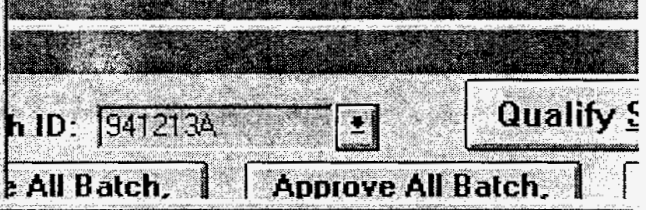

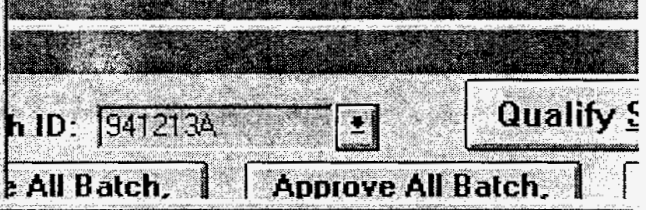

\section{Control Chart! Pro}

$7:$

- $\square x$

File Edit Graph Qptions

Di

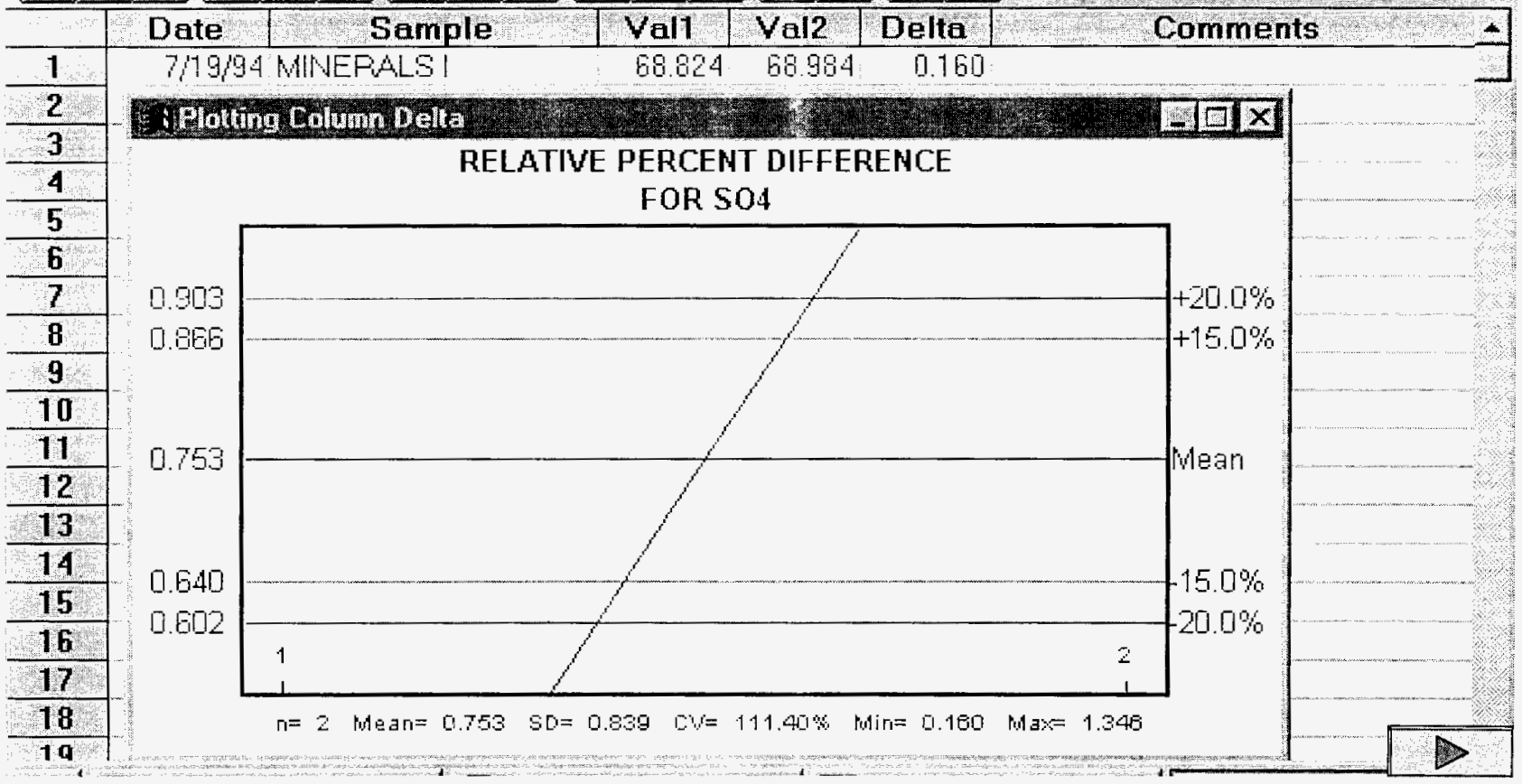




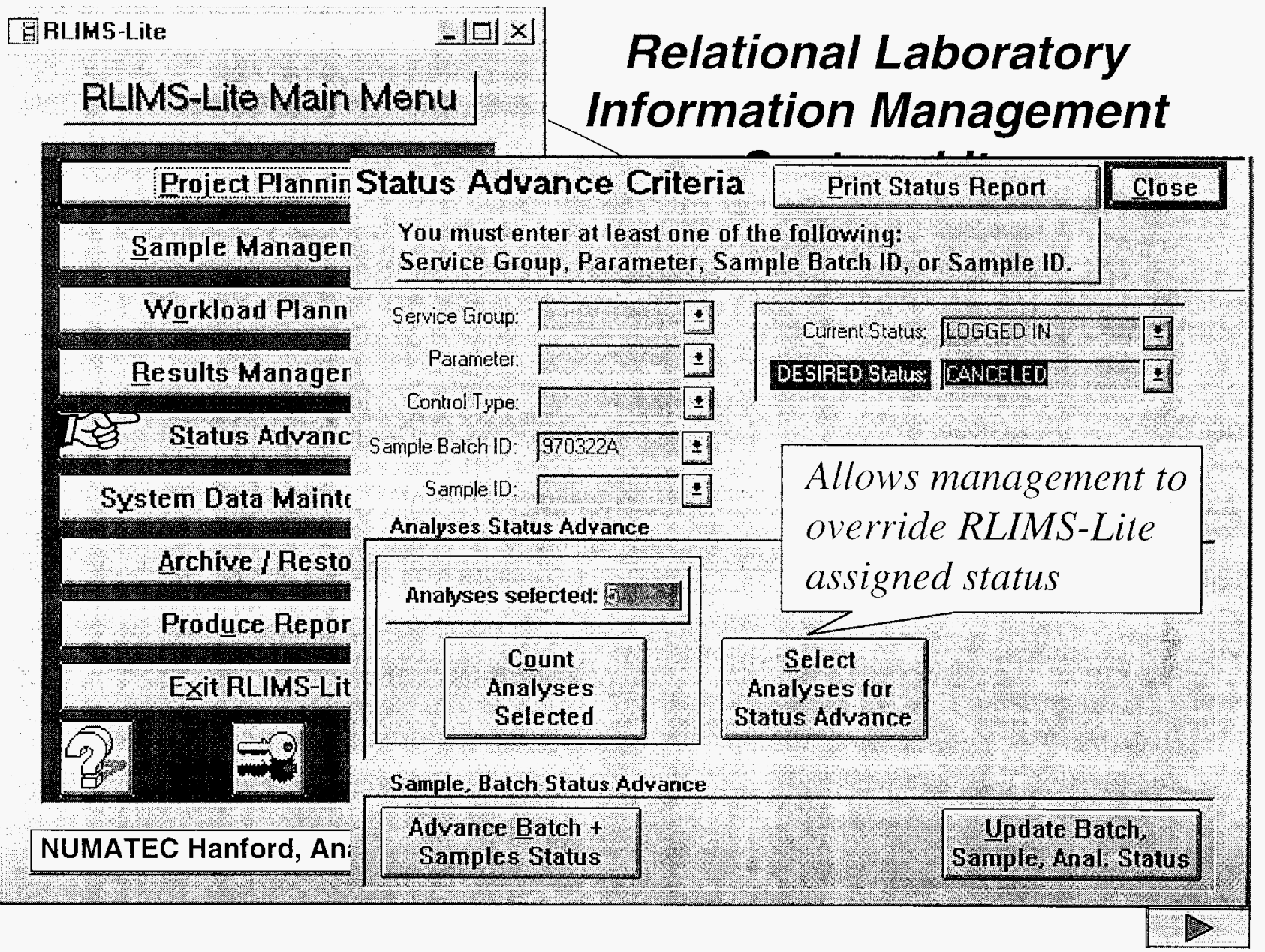




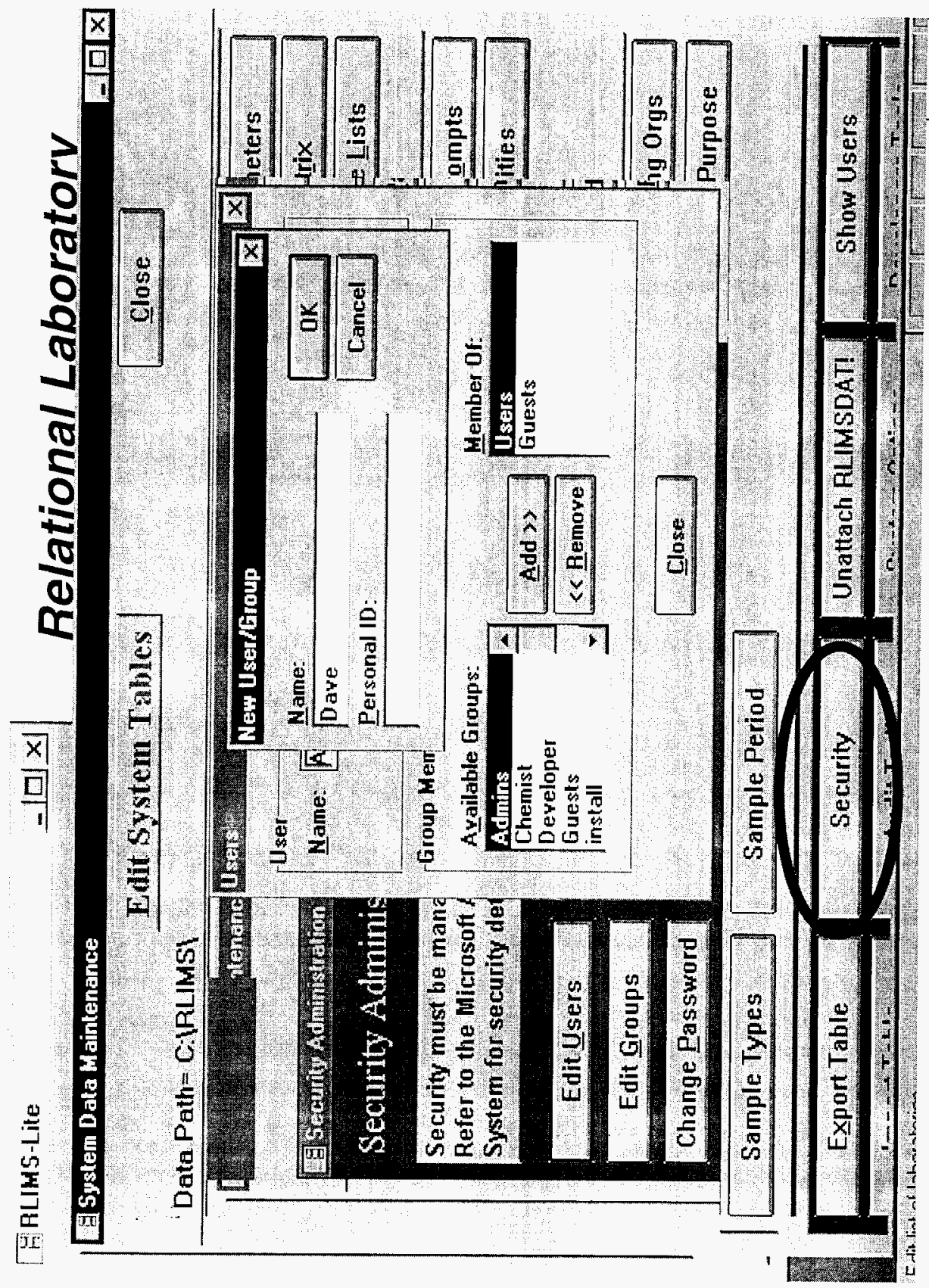




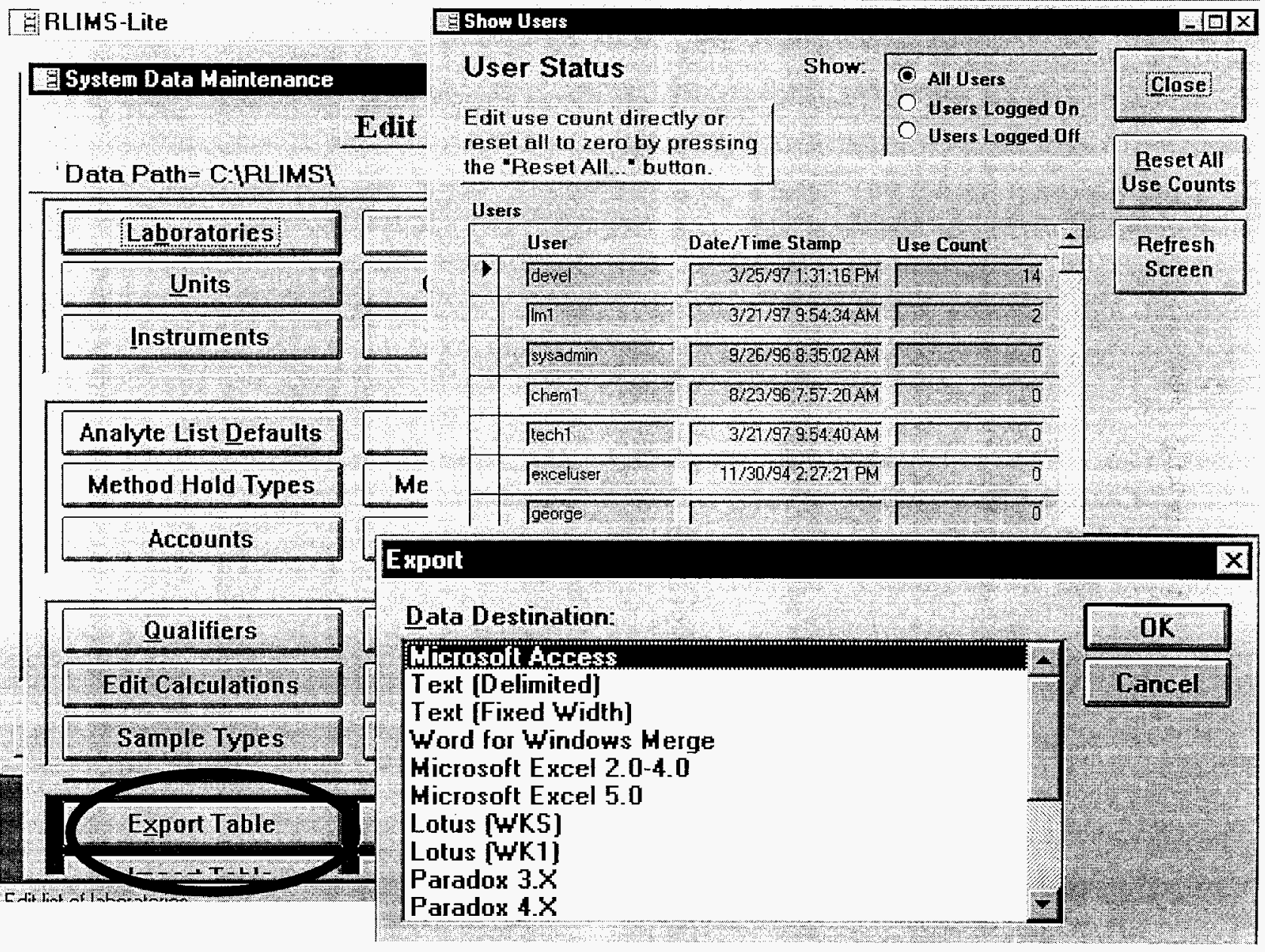




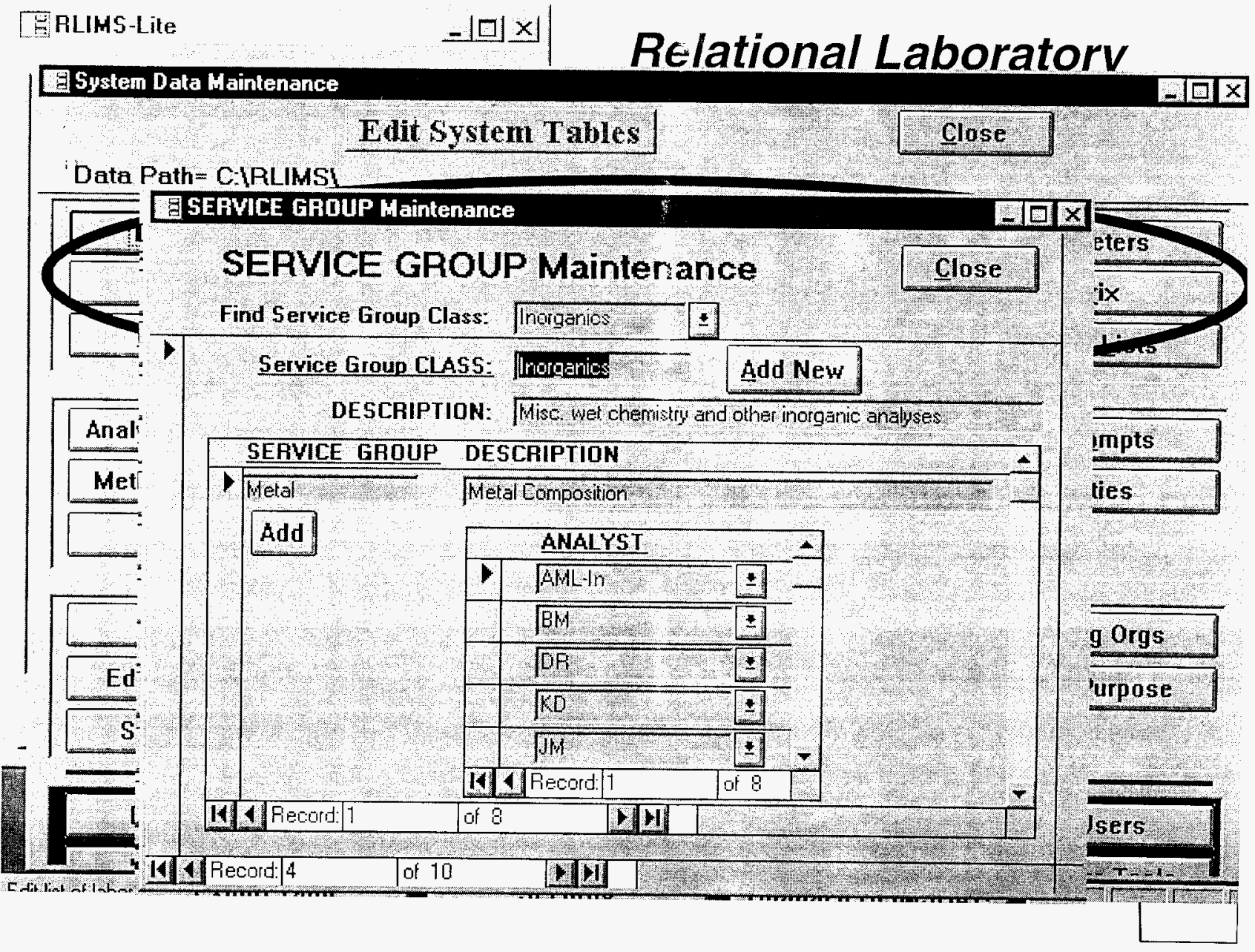




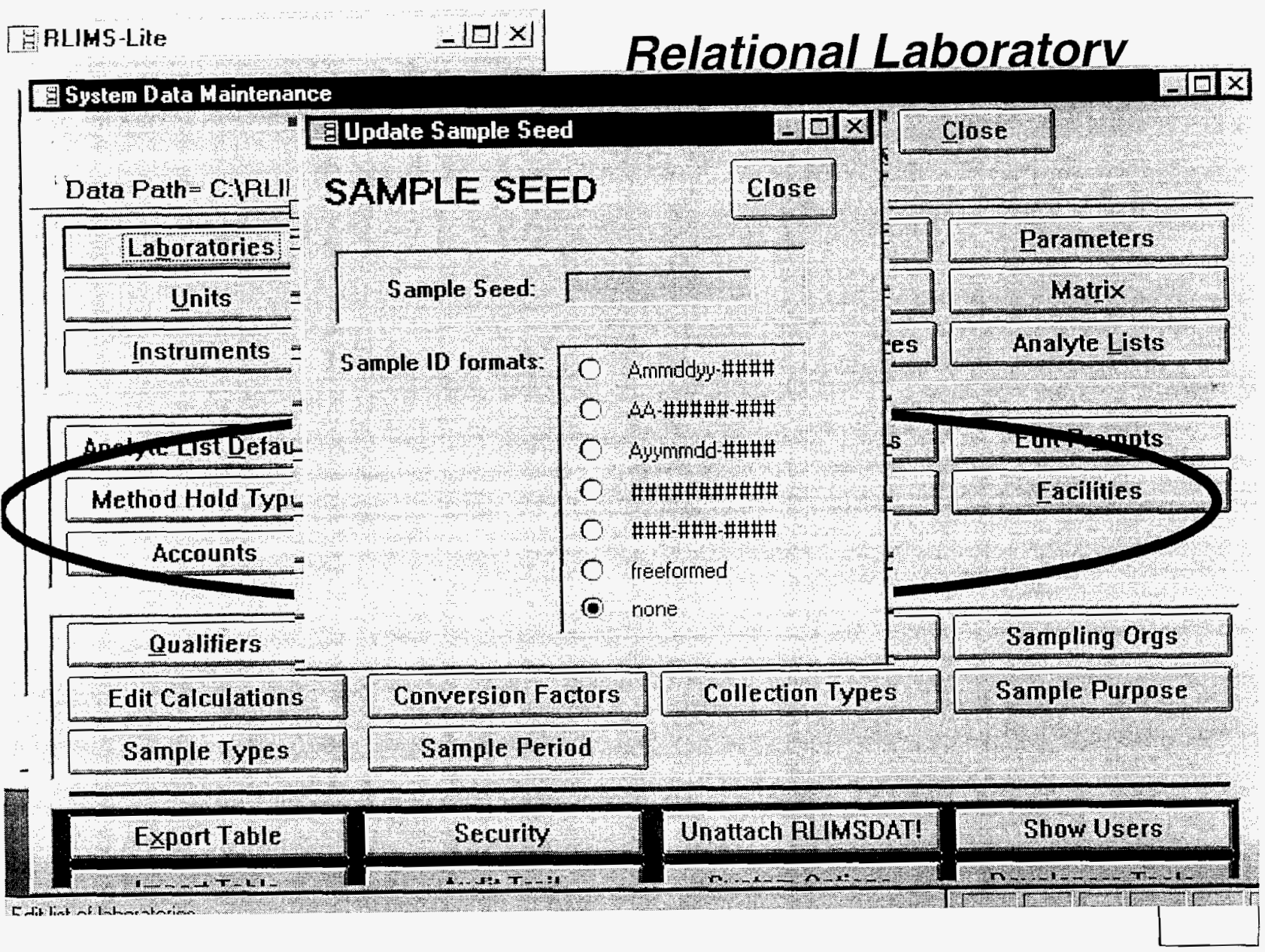




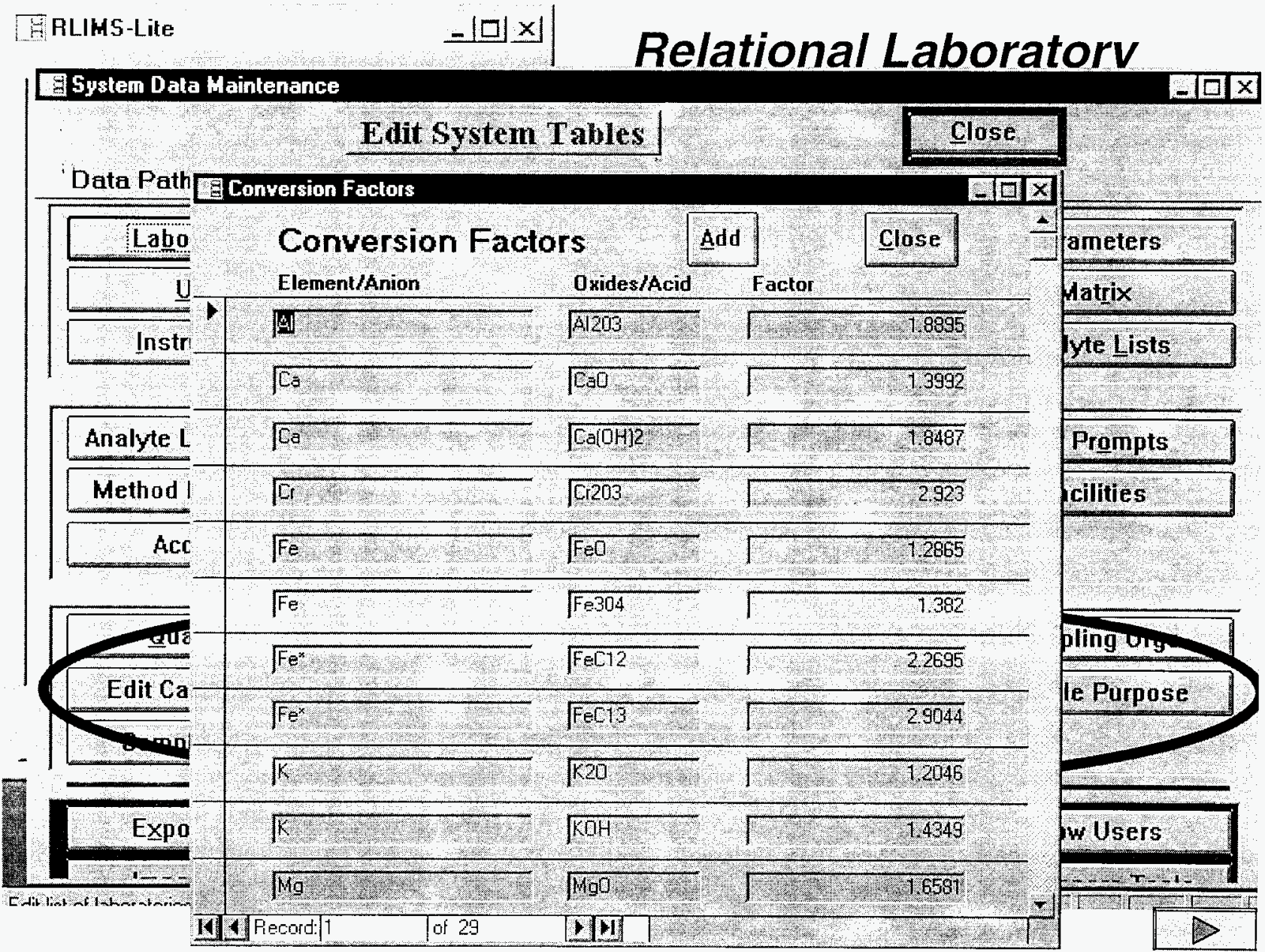


RLIMS-Lite Main Menu

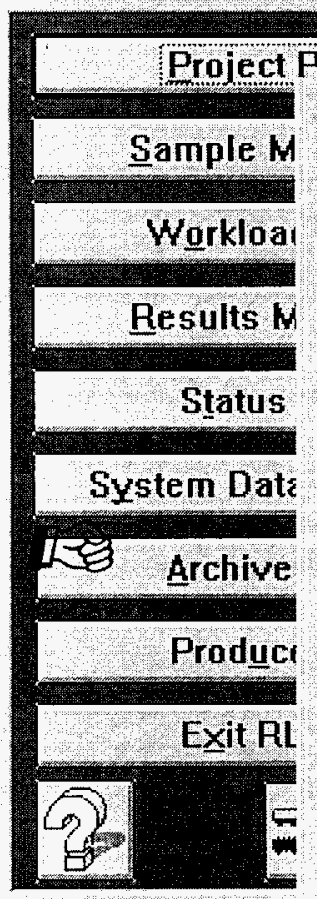

annina:

c All Stat Data

5 Standar Data
Relational Laboratory Information Management System-Lite

Archive/L Iete/Restore Options

$r$ All Samp = Data

$\Gamma$ Sample $\mathrm{E}$ Itches By Date

C Sample I ta By Pioject

S All Wor foad Planning

$r$ Work 'ad Planning by Date

StartDate

\&

Project RCRA Groundwater Volatiles

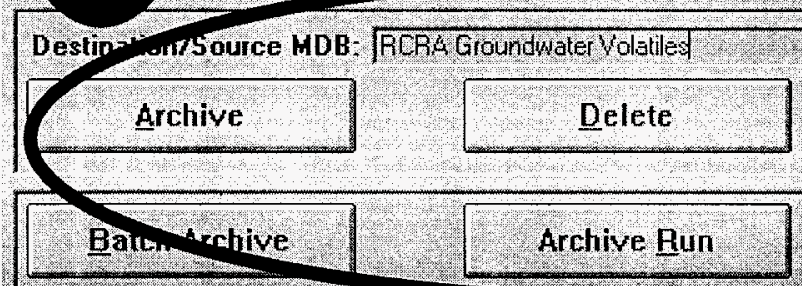

Şelecmm g

Restore

NUMATEC Hanf, 


\section{EAL SAMPLE RESULTS - BATCH 941102A}

01-A106-96

Project: 300-FF-1

Customer: LCHulstrom

Matrix SOL

Sample ID

SFE DRO 1

Leved (lowimed) Lant

DateReceivert

11.2194

Field Sample ID: EAL 000121

\begin{tabular}{|c|c|c|c|c|}
\hline CAS Ho. & Anatyte & Concentration & Units & 0 \\
\hline & Decme & NiA & uage & \\
\hline & Doovite & 138193 & Waig. & \\
\hline & Dodocane & 15.292 & ugrig & \\
\hline & Eicosime & 141.084 & ugig & \\
\hline & Hexacosane & 138.292 & Uarda & \\
\hline & Hexadecare & 153.354 & ung & \\
\hline & Otaonane & 136.037 & Lag & \\
\hline & Octadecane & 147.228 & ugdg & \\
\hline & Tetracosane & 139.348 & Lggia & \\
\hline & Tetradocare & 84.716 & Lagig & \\
\hline
\end{tabular}

Sample ID SFE DRO 10

Levet (lonimed):

DateReceivet

Field Sample ID:

\begin{tabular}{|c|c|c|c|c|}
\hline CAS HO. & Anatyte & Concentration & Units & $Q$ \\
\hline & Decane & NiA & wagig & \\
\hline & Doonane & NiA & ugdg & \\
\hline & Dodecine & WIA & Loge & \\
\hline
\end{tabular}




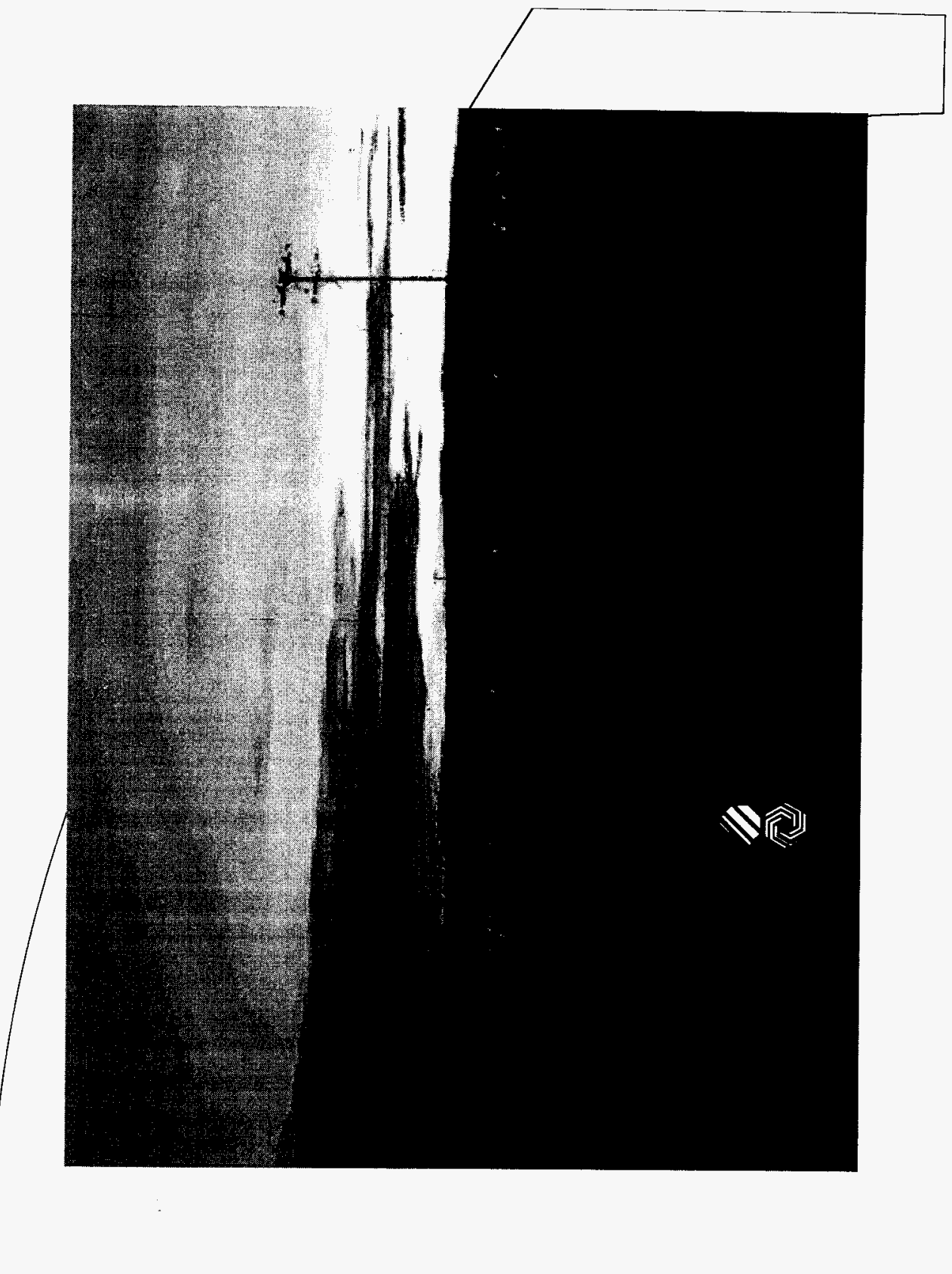




\section{INFORMATION CLEARANCE FORM}

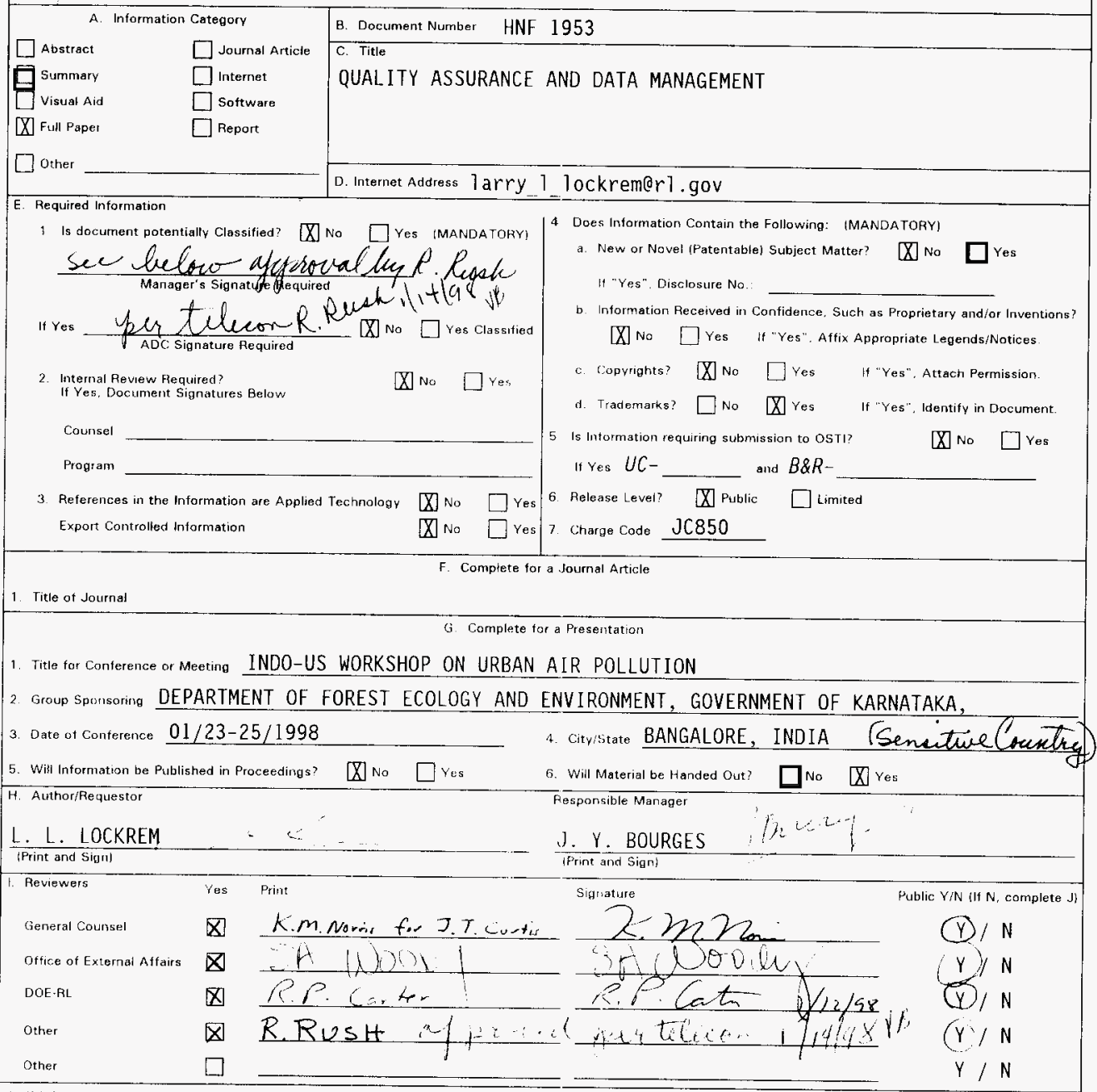

J. If Information Includes Sensitive Information and is not to be released to the Public indicate category below.

[. Applied Technology $\quad \square$ Psotected CRADA

$\square$ PersonalifPrivate $\square$ Export Controlled

$\square$ Proprietary $\square$ Procurement-Sensitive

[ Business Sensitive $\square$ Patentable

$\square$ Predecisional $\square$ Othe: ispecify)

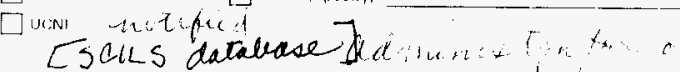

$\kappa$. If Additional Comments, Please Attach Separate Sheet

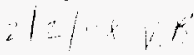

Information Clearance Approval

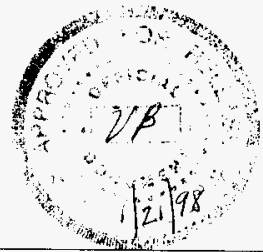


THIS PAGE INTENTIONALLY LEFT BLANK 


\section{RELEASE AUTHORIZATION}

Document Number: HNF-1953

Document Title:

Quality Assurance and Data Management

This document, reviewed in accordance with DOE Order 1430.1D, "Scientific and Technical Information Management," and DOE G 1430.1D-1, "Guide to the Management of Scientific and Technical Information," does not contain classified or sensitive unclassified information and is:

\section{APPROVED FOR PUBLIC RELEASE}

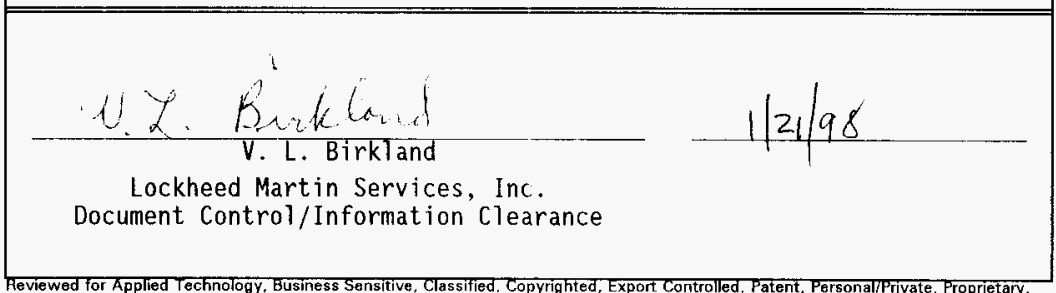

Protected CAADA. Trademark, Unclassified Controlled Nuclear Information.

COPYRIGHT LICENSE NOTICE. By acceptance of this article, the publisher and/or recipient acknowledtes the U.S. Government's right to retain a nonexclusive, royalty-free license in and to any copyright covering this paper.

LEGAL DISCLAIMER. This report was prepared as an account of work sponsored by an agency of the United States Government. Neither the United States Government nor any agency thereof. not any of their employees, nor any of their contractors, subcontractors or their employees, makes any warranty, express or implied, or assumes any legal lisbility or responsibility for the accuracy, completeness, or any third party's use or the results of such use of any information, apparatus, product, or process disclosed, or represents that its use would not infringe privately owned rights. Reference herein to any specific commercial product, process, or service by trade name, trademark, manufacturer, or otherwise, does not necessarily constitute or imply its endorsement. recommendation, or favoring by the United States Government or any agency thereof or its contractors or subcontractors. The views and opinions of authors oxpressed herein do not necessarily state or reflect those of the United States Government or any agency thereof. This report has been reproduced from the best available copy. Prirted in the United States of America. 
THIS PAGE INTENTIONALLY

LEFT BLANK 